\title{
Sledovi poselitve iz zgodnje bakrene dobe v Hočah
}

\author{
Settlement remains from the Early Chalcolithic period \\ in Hoče (Slovenia)
}

\author{
Bine KRAMBERGER
}

\begin{abstract}
Izvleček
V članku so celovito predstavljeni sledovi poselitve iz zgodnje bakrene dobe, odkriti v letih 1988 in 1989 ob gradnji orglarske delavnice v Spodnjih Hočah. Raziskave so med drugim razkrile pet naselbinskih jam, jame za stojke ter lončenino in kamnita orodja iz tega časa. Keramično gradivo kaže tehnološke, oblikovne in ornamentalne značilnosti lasinjske kulture in ne odstopa od gradiva, ki ga poznamo iz sočasnih bližnjih naselij v Podravju in Dravinjskih goricah. Povezave se kažejo predvsem s sočasnimi naselji na Dolenjskem, Gorenjskem in Štajerskem, v nekoliko manjši meri z naselji v Prekmurju in na zahodnem Madžarskem.
\end{abstract}

Ključne besede: severovzhodna Slovenija; Spodnje Hoče; zgodnja bakrena doba; naselje; zemljanke; keramične najdbe; kamnito orodje

\begin{abstract}
The article presents settlement remains from the Chalcolithic period, which were found in the years 1988 and 1989 , while the construction of an Organ Workshop in Spodnje Hoče (north-eastern Slovenia). Among other things, the research has revealed five settlement pits, post holes, pottery, and stone tools from this period. The ceramic assemblage shows technological, morphological, and ornamental characteristics of the Lasinja culture, and it does not deviate from the material known from the nearby Lasinja settlements at the Drava Plain and Dravinja Hills (north-eastern Slovenia). The connections are mostly recognised with the Dolenjska (south-eastern Slovenia), Gorenjska (north-western Slovenia), and Styria in Austria. The connections with settlements in the Prekmurje region and western Hungary are recognised to a lesser extent.
\end{abstract}

Keywords: North-eastern Slovenia; Spodnje Hoče; Early Copper Age; settlement; pit-houses; pottery; stone tools

Arheološko najdišče leži na nadmorski višini med 278,2 in 279,9 m v centru današnjega naselja Spodnje Hoče pri Mariboru, na stiku doline Hočkega potoka pod Pohorjem in obsežno Dravsko ravnjo. Geološko osnovo na tej ravnici sestavljajo večinoma naplavinske plasti, predvsem mulj in pesek iz zgornjega pliocena in spodnjega pleistocena, ki so jih čez dravski prod nanesli potoki. ${ }^{1}$ Pohorski

\footnotetext{
1 Žnidarčič, Mioć 1988; Mioć, Žnidarčič 1988.
}

potoki so namreč izrazito hudourniškega značaja, kar pomeni, da ob večjih nalivih hitro narastejo in začnejo poplavljati, pri tem pa $z$ višje ležečih območij s seboj prinašajo mnogo finega gradiva.

V preteklosti so Hočki potok, podobno kot ostale pohorske potoke med Zgornjim Radvanjem na severu in Spodnjo in Zgornjo Polskavo na jugu, umetno speljevali in koristili za namakanje polj in dotok pitne vode $\mathrm{v}$ naselja na ravnini. Ker so na prehodu na ravnino potoki hitro poniknili $\mathrm{v}$ 
dravskem produ, je bila notranjost dravskega polja namreč sušna. Ti kanali so obenem $\mathrm{v}$ deževnem obdobju služili za odvajanje preobilne hudourniške vode. ${ }^{2}$

Da je bila ravnina poseljena $\mathrm{v}$ bakreni, pozni bronasti in mlajši železni dobi, nato $\mathrm{v}$ rimskem obdobju in tudi v zgodnjem srednjem veku, so pokazala izkopavanja Zavoda za varstvo kulturne dediščine Slovenije in podjetja PJP, med letoma 1988 in $2018 .^{3}$

O teh raziskavah je bilo doslej le malo objavljenega. Edini nekoliko večji izbor gradiva je objavila vodja izkopavanja v letih 1988-1989 Mira Strmčnik Gulič v zborniku "Hoče - 850". V prispevku je predstavila tudi nekaj keramičnih najdb iz bakrenodobnega naselja in kamnitih artefaktov. Slednje je leta 1993 deloma objavila že Marija Lubšina Tušek. ${ }^{4}$

Z bakrenodobnim naseljem v Spodnjih Hočah sem se podrobneje ukvarjal med letoma 2010 in 2014 pri pripravi doktorske disertacije $\mathrm{z}$ naslovom "Naselbinske strukture in keramični zbiri v petem tisočletju pred našim štetjem $\mathrm{v}$ severovzhodni Sloveniji" avtor tega članka. ${ }^{5}$

\section{ARHEOLOŠKE RAZISKAVE V SPODNJIH HOČAH}

Najdišče severozahodno od župnijske cerkve sv. Jurija v središču Spodnjih Hoč (sl. 1) so odkrili leta 1988 ob gradnji večjega objekta (na parcelah št. 615/2 in 615/3, k. o. Spodnje Hoče), namenjenega izdelovanju cerkvenih glasbil, v lasti podjetja Orglarska delavnica Maribor. Območje je danes zavarovano in vpisano v Register nepremične kulturne dediščine kot Spodnje Hoče - Osrednji del arheološkega najdišča Hoče (EŠD 8976). ${ }^{6}$

Leta 1988 in leto kasneje je Zavod za varstvo naravne in kulturne dediščine Slovenije (ZVKDS,

2 Baš 1937, 326; glej tudi Pak 1964, 75-77; Pak 1998, 592-594.

3 Strmčnik Gulič 1989; 1990a; 1990b, 135-136, sl. 1; ead. 1996; 2003; Ciglenečki, Strmčnik Gulič 2002; Kajzer Cafnik, Predan 2006, 141.

4 Strmčnik Gulič 1996, t. 1; 2: 1; 3; prim. z Lubšina Tušek 1993, 124, t. 24: 13-16.

${ }^{5}$ Prim. Kramberger 2014a, 243, t. 11-12 s Kramberger 2014b, t. 181-200.

${ }^{6} \mathrm{EŠD}=$ evidenčna št. enote dediščine (zbirka $\left.R K D\right)$ / Heritage Register Number (database RKD) [https:// gisportal.gov.si/portal/apps/webappviewer/index.html?id $=\mathrm{df5b} 0 \mathrm{c} 8 \mathrm{a} 300145 \mathrm{fda} 417 \mathrm{eda6b} 0 \mathrm{c} 2 \mathrm{~b} 52 \mathrm{~b}]$.

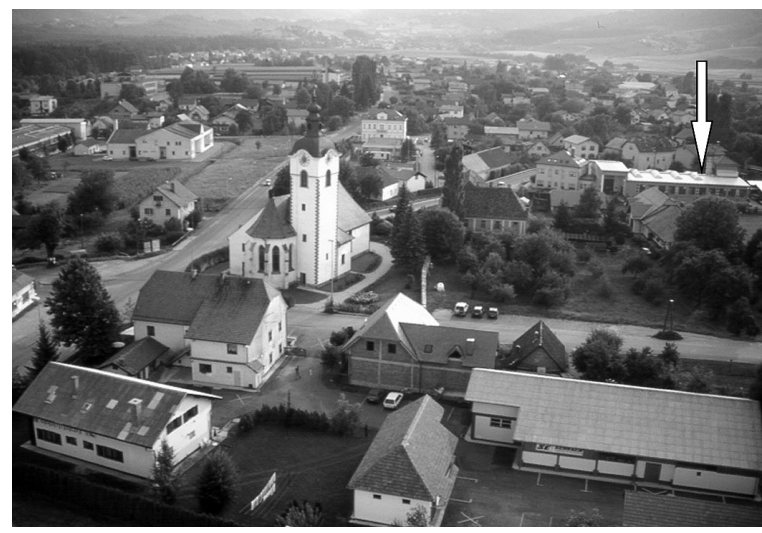

Sl. 1: Spodnje Hoče, pogled z vzhoda. Župnijska cerkev sv. Jurija in območje arheoloških raziskav leta 1997 (puščica označuje stavbo podjetja Orglarska delavnica Maribor). Fig. 1: Spodnje Hoče, view from the east. St. George‘s Parish Church and the area of archaeological investigations in 1997 (the arrow indicates the building of the workshop "Orglarska delavnica Maribor".

OE Maribor) izvedel arheološko izkopavanje pod vodstvom Mire Strmčnik Gulič na površini skupne velikosti $1070 \mathrm{~m}^{2}$. Prvo leto so se izkopavanja izvajala severno in južno od gradbene jame za orglarsko delavnico, ki je v celoti uničila del najdišča, naslednje leto pa so jih nadaljevali zaradi gradnje jarka za kablovod in ponikovalnice severno in zahodno od orglarske delavnice.

Območje orglarske delavnice se je po gostoti in ohranjenosti naselbinskih ostalin izkazalo za najbogatejši del tega arheološkega najdišča. Odkriti so bili sledovi poselitve iz bakrene in bronaste dobe ter rimskodobno poselitveno jedro z zelo izpovednimi arhitekturnimi ostalinami in drobnim gradivom (sl. 2-4). ${ }^{7}$

Okoli 250 m jugovzhodno od orglarske delavnice so bila leta 1997 zaradi gradnje hitre ceste med Mariborom in Slivnico izvedena arheološka izkopavanja ob trasi nekdanje magistralne ceste (sl. 2) (parc. št. 650/1 in 650/2), ki jih je prav tako vodila M. Strmčnik Gulič. Najpomembnejše odkritje na tem območju, ki je obsegalo okoli 1300 $\mathrm{m}^{2}$ površine, so zgodnjesrednjeveške zemljanke. Poleg njih so izkopavalci naleteli na naselbinske ostanke iz pozne bronaste dobe, na paleostrugo in najdbe iz rimskega obdobja $\mathrm{v}$ naplavinskih plasteh, ki so posledica delovanja hudournika v času rimskega imperija. ${ }^{8}$

7 Strmčnik Gulič 1989; 1990a; 1990b, 135-136, sl. 1; ead. 1996.

8 Ciglenečki, Strmčnik Gulič 2002; Strmčnik Gulič 2003. Celovito objavo v zbirki Arheologija na avtocestah 


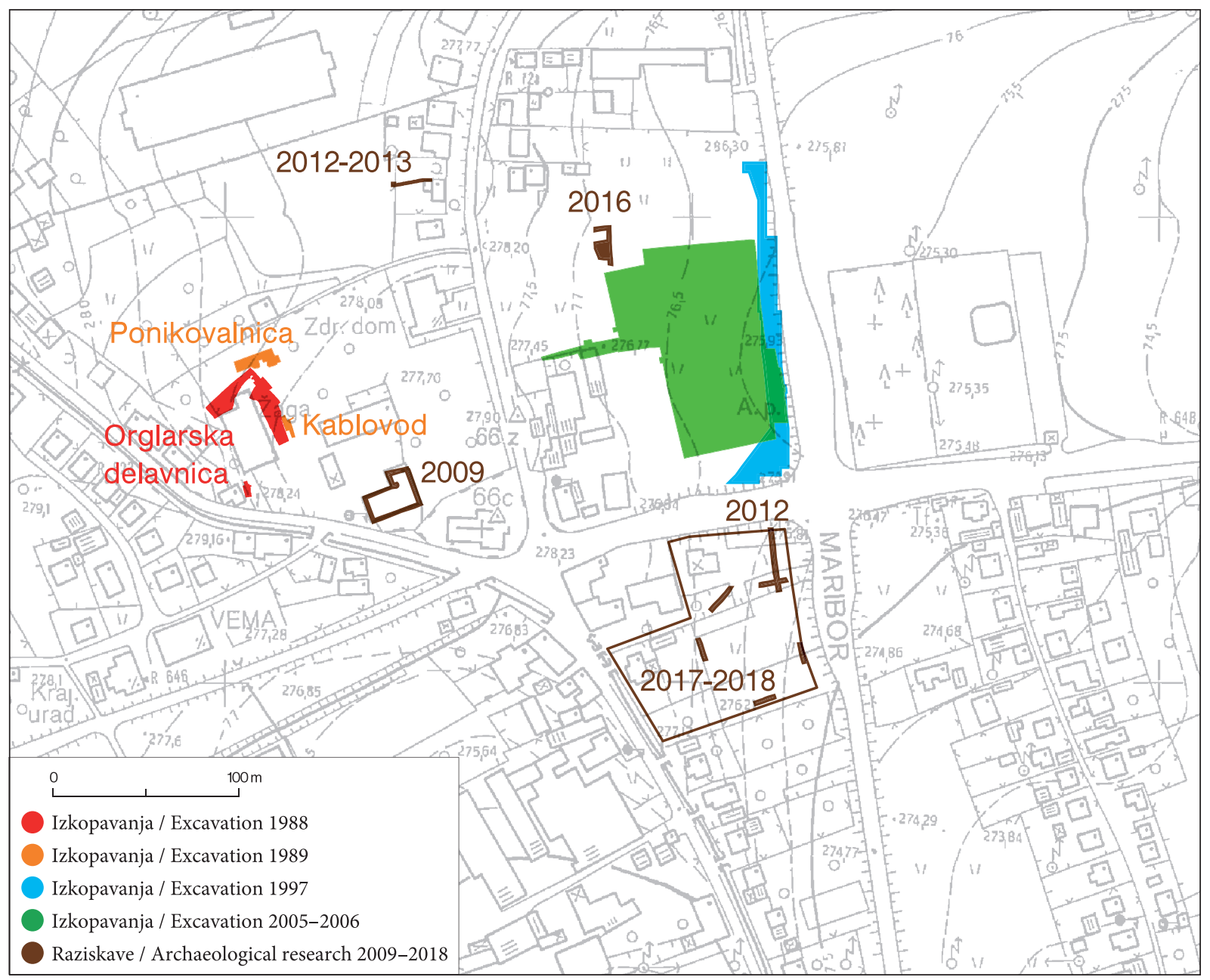

Sl. 2: Spodnje Hoče. Območja arheoloških raziskav med letoma 1988 in 2018. M. = 1:4000.

Fig. 2: Spodnje Hoče. Areas of archaeological investigations between 1988 and 2018. Scale = 1:4000.

(Vir / Source: TTN5, lista I272300A, I273300A, @ Geodetska uprava RS)

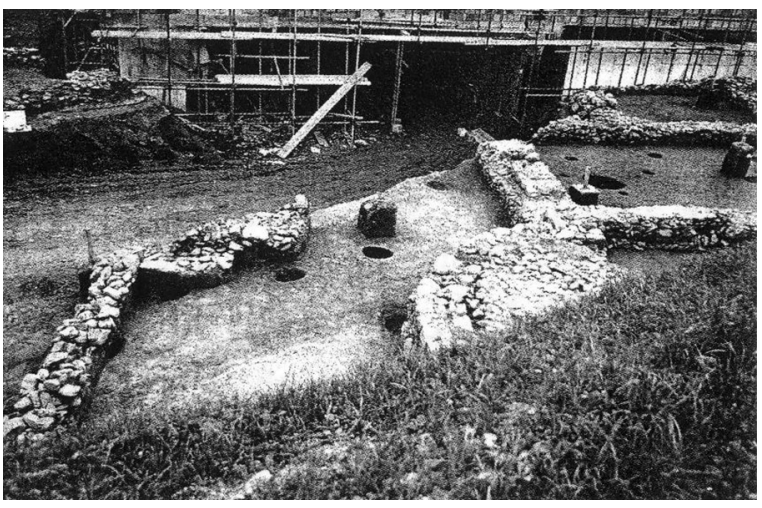

Sl. 3: Spodnje Hoče - Orglarska delavnica; izkopavanje leta 1988. Pogled s severozahoda na gradbeno jamo in ob njej odkrite temelje rimskega objekta ter ostanke prazgodovinskih jam za stojke.

Fig. 3: Spodnje Hoče - Orglarska delavnica; excavation in 1988. View from the northwest to the construction pit and to the foundation of a Roman building and the remains of prehistoric post-holes.

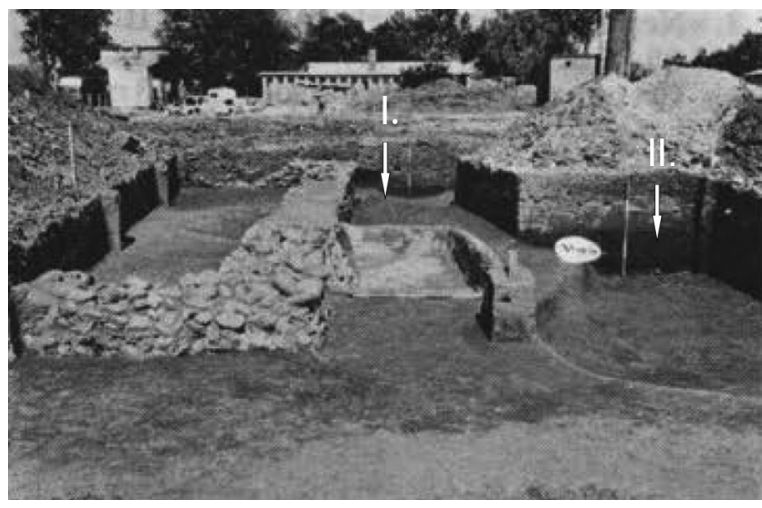

Sl. 4: Spodnje Hoče - Orglarska delavnica. Izkopavanje leta 1989, sonda za ponikalnico. Pogled z jugovzhoda na jami iz zgodnje bakrene dobe (zemljanka I in II).

Fig. 4: Spodnje Hoče - Orglarska delavnica. Excavation in 1989, the "sinkhole trench". View from the southeast on the pits from the Early Copper Age (Pit-houses I and II). 
Največje izkopavanje je v Spodnjih Hočah potekalo v letih 2005 in 2006 zaradi gradnje trgovskega centra Hofer, vodila sta ga Primož Predan (podjetje PJP) in Mira Strmčnik Gulič (ZVKDS, OE Maribor). Raziskano je bilo $8407 \mathrm{~m}^{2}$ veliko območje (sl. 2) (na parcelah št. 650/2, 650/3, 650/6, $650 / 7$ in 650/8, k. o. Spodnje Hoče), ki leži med župnijsko cerkvijo in traso hitre ceste. Tu so bile odkrite naselbinske jame iz zgodnjega srednjega veka, posamični objekti iz rimskega obdobja ter bivalne jame iz mlajše železne dobe $s$ kuriščem in značilno latensko lončenino. Indicev o starejši poselitvi po podatkih raziskovalcev na tem območju niso zasledili. To pomeni, da se bakrenodobno naselje $\mathrm{z}$ območja orglarske delavnice ni širilo daleč proti vzhodu. ${ }^{9}$

Tudi pri arheoloških nadzorih ob gradnjah in sondiranjih, ki so bili opravljeni po letu 2006 okoli starega župnišča in ob gradnjah kanalizacije, stanovanjske hiše, dozidavi trgovskega centra Hofer ter gradnji trgovskega centra Lidl (na parc. št. 762/2, 633/1, 650/3, 768/2, 765, 766 in 767, k. o. Spodnje Hoče), ${ }^{10}$ po poročanju izkopavalcev niso odkrili sledov bakrenodobne poselitve.

\section{NASELBINSKE JAME IZ BAKRENE DOBE}

Naselbinske ostaline iz bakrene dobe so bile torej ugotovljene le na območju izkopavanj v letih 1988 in 1989, kjer so se pojavljale na globini med 0,6 in $1 \mathrm{~m}$ pod današnjim površjem. Večina drobnega gradiva izhaja iz treh velikih jam v sondi za ponikovalnico leta 1989 (izkopavalci so jih interpretirali kot zemljanke). Ob gradbeni jami za orglarsko delavnico pa so bile iz tega časa odkrite deloma raziskana jama, ena od srednje velikih jam ter verjetno vsaj še ena jama za stojko $(s l .5) .{ }^{11}$

\section{Jama I (sl. 5)}

Ležala je severozahodno od gradbene jame za orglarsko delavnico in je bila ovalnega tlorisa, velikosti $2,2 \times 1,8 \mathrm{~m}$. Vsebovala je temno sivo

\footnotetext{
Slovenije pripravljamo na Centru za poizkopavalno obdelavo in raziskavo gradiva na ZVKDS, CPA.

9 Kajzer Cafnik, Predan 2006, 141; Vinder 2011, 16.

10 Murko, Predan 2010; Predan 2012; Predan, Čakš 2012; Vinder 2016; Predan 2017; Vinder 2018.

11 Opise naselbinskih jam povzemamo po objavah M. Strmčnik Gulič $(1989 ; 1990 ; 1996)$.
}

ilovnato plast, v kateri so bili najdeni kamnit tolkač iz serpentinita $\left(\right.$ t. 20: 10), ${ }^{12}$ sileks in posamični fragmenti keramike. Izkopavalci so jo interpretirali kot hrambno jamo. ${ }^{13}$

\section{Jama II (sl. 5)}

Okoli $4 \mathrm{~m}$ jugozahodno od jame I je bila tik ob zahodnem profilu izkopnega polja odkrita jama II, ki se je širila izven območja raziskav. V premeru je merila $5,41 \mathrm{~m}$ in je imela dve poglobitvi globine $40-60 \mathrm{~cm}$. Stene jame so bile poševne, dno valovito. $\mathrm{V}$ jami je bilo odkritih 80 keramičnih odlomkov, med katerimi je tipološko določljivih 8 kosov $(t$. 20: 1-9). Izkopavalci so domnevali, da bi lahko služila kot zemljanka. ${ }^{14}$

\section{Jama za stojko 7 (sl. 5)}

Okoli $21 \mathrm{~m}$ severovzhodno od jame II je bila odkrita temna lisa okroglega tlorisa s premerom $25 \mathrm{~cm}$. Iz nje po vsej verjetnosti izvira odlomek posode $\mathrm{z}$ držajem $\mathrm{v}$ obliki človeškega stopala $(t$. 21: 1), po katerem jo lahko datiramo v bakreno dobo. Podatki o lokaciji tega predmeta so se pri prenosu na razstavo v knjižnico v Hoče žal izgubili. Da izvira iz jame za stojko 7, bi lahko sklepali na podlagi ugotovitve, da ji pripadajo keramični odlomki iz vrečke z identifikacijskim listkom "jama 7, 1988". Lokacija se ujema tudi z informacijo izkopavalca Stanka Gojkoviča, da je bila posoda z apliko v obliki človeške noge odkrita v eni izmed majhnih jam oziroma jam za stojke. ${ }^{15}$

\section{Zemljanka I (sl. 4; 6)}

Jamo, veliko $6 \times 2,5 \mathrm{~m}$ in globoko do $30 \mathrm{~cm}$, so sestavljale tri krožne poglobitve. Odkrita je bila v sondi za ponikovalnico na globini od 0,6

12 M. Lubšina Tušek 1990, t. 108: 1; ead. 1993, 123-124, t. 24: 13 .

13 Strmčnik Gulič 1989, 226.

14 Strmčnik Gulič 1989, 226. V diplomski nalogi je M. Lubšina Tušek to jamo označila kot Zemunico I/1988 in ji pripisala odlomek sklede z jezičasto nalepko ( $t$. 20: 1), o kateri so se podatki kasneje izgubili (Lubšina Tušek 1990, 214, t. 108: 4; prim. s Kramberger 2014b, t. 200: 1855).

15 Odlomki posode $\mathrm{z}$ antropomorfno oblikovanim $\mathrm{dr}$ žajem so bili shranjeni z nekaterimi predmeti, objavljenimi leta 1996 (Strmčnik Gulič 1996), ter z listki posameznih najdb, razstavljenih v knjižnici v Hočah (prim. s Kramberger 2014b, t. 199: 1854). Domnevamo, da so keramične odlomke izločili ob prenosu držaja na razstavišče. 
do $0,7 \mathrm{~m}$. V osrednjem delu jo je poškodoval zid rimskega objekta, na zahodni strani pa rimska peč za žganje apna. ${ }^{16}$ Jama je bila zapolnjena $s$ temno rjavo ilovico in kosi ožgane zemlje, oglja ter keramičnimi odlomki. Od evidentiranih 635 črepinj je v katalogu predstavljenih 68 keramičnih predmetov, ki so bili sestavljeni iz 556 fragmentov (t. 1-8; 9: 1-10). V jami so bili najdeni še izvrtek sekire iz serpentinita $(t .9: 11)$, odlomek sekire iz lahkega belega kamna ( $t$. 9: 12) in odbitek roba glajene kamnite sekire iz sivorjavega kamna.

$\mathrm{Na}$ originalnih načrtih in $\mathrm{v}$ objavah je jama označena kot zemljanka, vendar so raziskave na bližnjem bolje ohranjenem bakrenodobnem naselju Zgornje Radvanje pokazale, da je podobne jame z okroglimi poglobitvami in brez jam za stojke težko interpretirati za zemljanke. ${ }^{17}$

\section{Zemljanka II (sl. 4; 6)}

Jugozahodno od t. i. zemljanke I je bila v razdalji 1,9 m odkrita jama šesterokotne oblike $\mathrm{z}$ zaobljenimi robovi. Merila je $5,7 \times 3,5 \mathrm{~m}$ in je bila do 52 $\mathrm{cm}$ globoka. Dno jame je bilo valovito, vkopano v glineno plast, le v vzhodnem delu jame so bila tla peščena. Zapolnjevala jo je temno rjava zemlja $z$ drobci ožgane ilovice, oglja, kosti ter keramičnimi odlomki in kamnitimi artefakti. ${ }^{18}$

Od 535 keramičnih najdb iz te jame predstavljamo v katalogu 96 predmetov, ki smo jih sestavili iz 461 odlomkov ( $t$. 10-15; 16: 1-10), poleg tega še kamnito sekiro $(t .17: 1)$, dleto $(t .16: 14)$, tri izvrtke ( $t$. 16: 11-13) in fragmentirane žrmlje ( $t$. 17: 2), ki so bili zanesljivo najdeni v tej jami.

Sodeč po objavi v zborniku "Hoče - 850 " so t. i. zemljanki II pripadali še kamen $\mathrm{z}$ delno navrtano luknjo ( $t$. 17: 3) ter v celoti ohranjena kamnita sekira z luknjo in njej pripadajoči izvrtek ( $t$. 17: 4,5), medtem ko je M. Lubšina Tušek te najdbe pripisala inventarju zemljanke III. ${ }^{19}$

\footnotetext{
16 Strmčnik Gulič 1990a, 174-175; ead. 1996, 109.

17 Prim. tlorise objektov, označenih na načrtu naselja v Zgornjem Radvanju (Kramberger 2014a, sl. 15). Celovita objava rezultatov raziskav Radvanja je v pripravi.

18 Strmčnik Gulič 1990a, 175; ead. 1996, 110.

19 Strmčnik Gulič 1996, sl. 5; prim. z Lubšina Tušek 1990, t. 109: 3-7; Lubšina Tušek 1993, 123-124, t. 24: 14-16. Podatkov o mikrolokaciji ni mogoče preveriti, predmeti so brez pripadajočih listkov razstavljeni v knjižnici Hoče.
}

\section{Zemljanka III (sl. 6)}

Tretja velika bakrenodobna jama je bila le deloma raziskana. $\mathrm{Na}$ južnem delu je segala izven območja raziskav, v osrednjem delu pa pod rimsko peč za žganje apna, pod katero izkopavanja niso posegala, peč je ohranjena in situ.

$\mathrm{V}$ južnem profilu sonde je bila zemljanka III vidna pod plastmi iz rimskega obdobja (sl. 6: plast 2 ) in pozne bronaste dobe (plast 4). Merila je 5,5× $4,6 \mathrm{~m}$ in je bila vkopana $\mathrm{v}$ peščeno-ilovnata tla. ${ }^{20}$

$\mathrm{V}$ zemljanki sta bili ugotovljeni dve kulturni plasti in zgostitev ožgane ilovice z ogljem (sl. 6). Plast 9 je zapolnjevala poglobitev na dnu jame $\mathrm{v}$ velikosti 4,2 $\times 2,2 \mathrm{~m}$ in globine do $26 \mathrm{~cm}$. To je v enem delu prekrivala $60 \mathrm{~cm}$ široka in $10 \mathrm{~cm}$ debela koncentracija ožgane ilovice in oglja, ki bi glede na podobne jame iz bližnjega Radvanja lahko bila ostanek ognjišča (plast 8 ), ${ }^{21}$ nad njo in plastjo 9 pa je ležala plast 5 .

Na robu jame so bile odkrite štiri jame za stojke (št. 10-13). Jama za stojko 10 na zahodni strani zemljanke je vsebovala keramične odlomke, ki so sodeč po fakturi po vsej verjetnosti iz zgodnje bakrene dobe. Ostale jame za stojke so bile brez omembe vrednih najdb in jih v bakreno dobo umeščamo pogojno, na podlagi njihove lege.

K inventarju jame sodijo kamniti tolkač $(t .17$ : 8 ) in 184 odlomkov lončenine $(t .17: 9-11 ; 18$; 19), 62 od teh jih pripada rekonstruirani skledi (t. 18: 4), 35 rekonstruiranemu loncu (t. 19: 5), 43 pa podobnemu, prav tako rekonstruiranemu loncu (t. 19: 3).

V zemljanki III naj bi bila odkrita tudi "en primerek čudovito izostrenega rezilca (sekirica)" in izvrtek sekire. ${ }^{22}$ Po opisu predmetov in zabeležkah o njuni legi gre verjetno za kamnit izdelek na $t$. 17: 7, ki je edina še preostala kamnita najdba na razstavi v knjižnici Hoče, in izvrtek sekire ( $t$. 17: 6). Slednji je bil namreč po zabeleženih podatkih najden "ob vzhodnem profilu, kv. 16, gl. 55 cm" in “... v rahli poglobitvi ... ob južnem profilu, v katerega se zemljanka širi ...", zabeležena št. kvadranta ustreza legi zemljanke III.

Najdbe iz bakrenodobnega naselja v Spodnjih Hočah hranijo Zavod za varstvo kulturne dediščine Slovenije - OE Maribor, Pokrajinski muzej Maribor in Mariborska knjižnica (enota Knjižnica Hoče).

20 Strmčnik Gulič 1990a, 174-175; ead. 1996, 110.

21 Prim. s Kramberger 2010, 312, sl. 4, app. 1; id. 2014a, 241, sl. 16.

22 Strmčnik Gulič 1996, 110. 


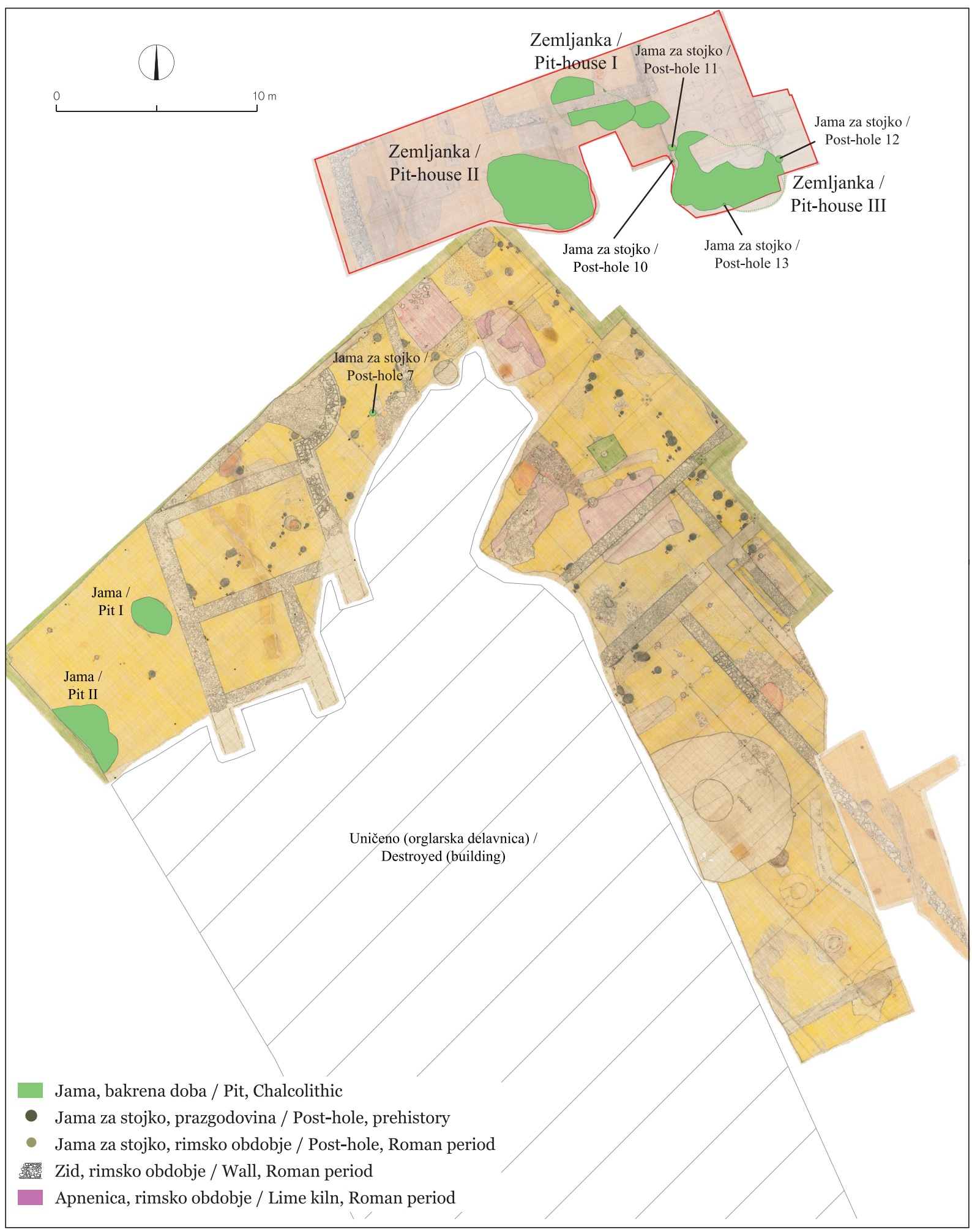

Sl. 5: Spodnje Hoče - Orglarska delavnica. Izkopavanja leta 1988 in 1989 (prim. sl. 2). Generalni načrt najdišča z označenimi jamami iz zgodnje bakrene dobe. M. = 1:300.

Fig. 5: Spodnje Hoče - Orglarska delavnica. Excavations in 1988 and 1989 (cf. Fig. 2). General plan of the site with marked pits from the Early Copper Age. Scale = 1:300. 


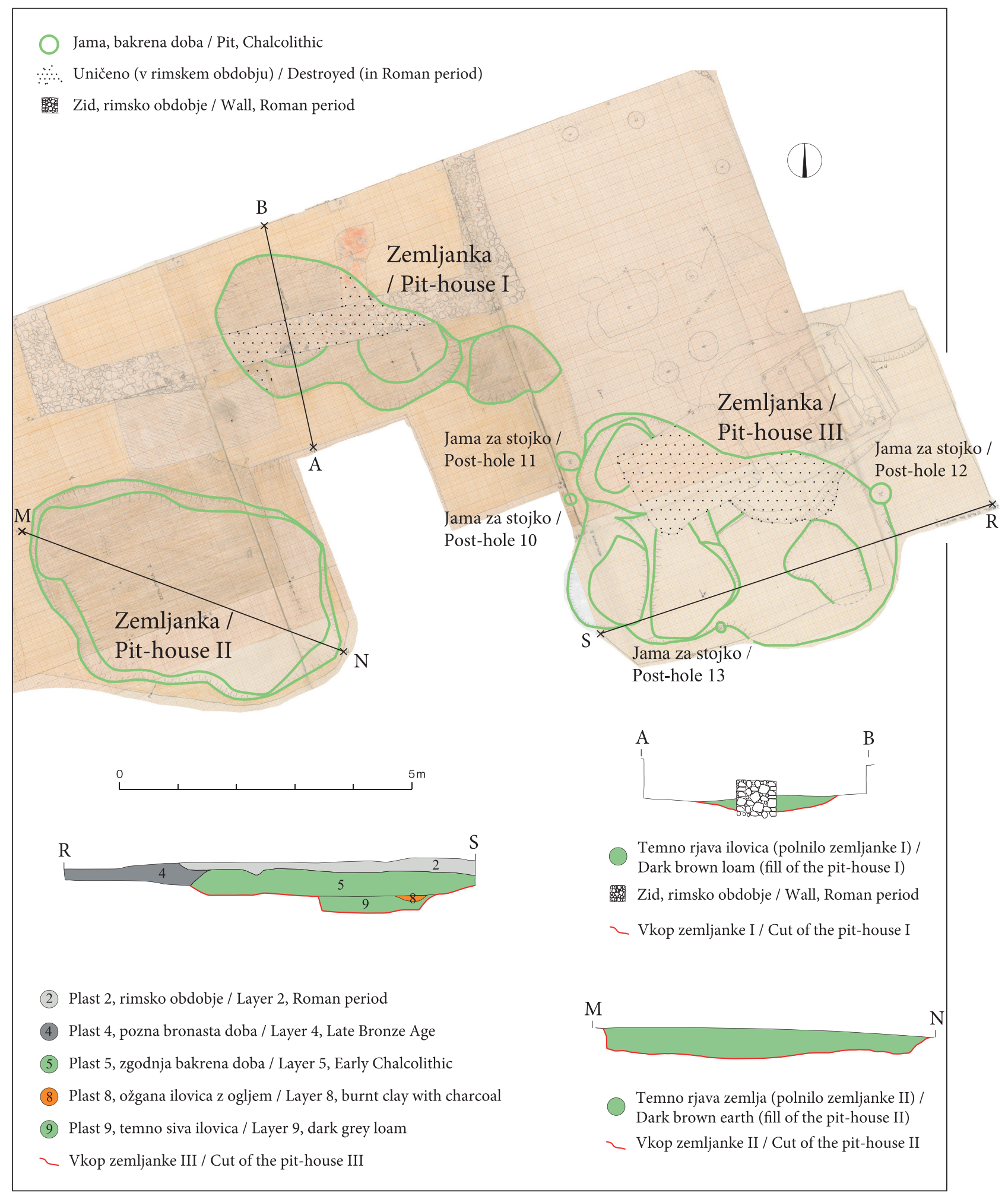

Sl. 6: Spodnje Hoče - Orglarska delavnica. Izkopavanje leta 1989, vzhodni del sonde za ponikalnico (prim. sl. 2). Generalni tloris z označenimi jamami (zemljanke I, II, III) iz zgodnje bakrene dobe s prerezi (A-B, M-N, R-S). M. = 1:100. Fig. 6: Spodnje Hoče - Orglarska delavnica. Excavation in 1989, the eastern part of the trench (cf. Fig. 2). General plan with marked pits (pit-houses I, II, III) from the Early Copper Age with sections (A-B, M-N, R-S). Scale = 1:100. 


\section{KERAMIČNE NAJDBE}

Lončenina, odkrita $\mathrm{v}$ bakrenodobnem naselju v Spodnjih Hočah, je štela skupaj 1584 fragmentov $(33,9 \mathrm{~kg})$, vendar se je po rekonstrukcijskem postopku število zmanjšalo na 895 , tj. za 43,5 $\%$, kar pomeni, da je delež sestavljene keramike sorazmerno velik. Precej posod je bilo mogoče rekonstruirati v celotnem profilu $(t .3: 3 ; 4: 1,2 ; 6$ : $2 ; 7: 6 ; 10: 3 ; 11: 8-10 ; 12: 4,8,9 ; 18: 4 ; 19: 3-5)$, v večini primerov pa je $\mathrm{v}$ celoti razpoznavna oblikovanost zgornjega dela ostenja (npr. t. 5: 1-3; 6: $3 ; 7: 8 ; 10: 4 ; 14: 1-3 ; 15: 1-3 ; 20: 6)$.

Od 895 kosov lončenine je bilo analiziranih 219 (dobrih $24 \%$ ), od tega je v katalog vključenih 153 kosov $(t .1-8 ; 9$ : 1-10; 10-15; 16: 1-10; t. 17: 9-11; 18; 19; 20: 1-9; 21: 1-3). Preostalih 676 kosov predstavlja manj značilne keramične odlomke, večinoma ostenij.

Keramični izdelki so bili oblikovani prostoročno, večinoma iz glin brez primesi (zelo finozrnate lončarske mase $-74 \%$ ) ali s posameznimi zrni kremena (finozrnate lončarske mase - $22 \%$ ). Njihova površina je bila pred žganjem praviloma skrbno obdelana, brisana $(83 \%)$ in $\mathrm{v}$ nekaterih primerih premazana $(7 \%)$ s premazom rdeče $(t$. 1: $3 ; 2: 4 ; 8: 2,3 ; 9: 6 ; 12: 1 ; 16: 6,10 ;$ sl. 8: 1-3), rdečerjave $(t .10: 1 ; 13: 4,5 ; 16: 2)$ ali zelo temno sive barve ( $t$. 10: 5). Keramični predmeti so bili nato žgani nepopolno oksidacijsko (76 \%) ali nepopolno oksidacijsko $\mathrm{z}$ redukcijsko atmosfero $\mathrm{v}$ končni fazi $(24 \%) .^{23}$

Od 219 analiziranih odlomkov je okrašenih 81 (37\%). Ornament (sl. 7) je narejen pred žganjem, najpogosteje $\mathrm{z}$ vrezovanjem (52\%, npr. t. 1: 12; 2 : $1,2,5,6 ; 3: 6,8-10,13,14)$ ali vtiskovanjem paličici podobnega orodja $\mathrm{v}$ površino predmeta ( $15 \%$ : $t$. 3: 7,15), velikokrat tudi v kombinaciji obeh tehnik (15\%, npr. t. 1: 10). Pogoste so tudi nalepke ali aplike (14\%, npr.t. $1: 1 ; 11: 5,6)$. Slednje se v nekaj primerih pojavljajo skupaj z vrezanim okrasom (4 $\%$, npr. t. 2: 3,4).

Izmed vseh keramičnih oblik so najpogosteje okrašeni lonci (39) in vrči (24). Večina jih ima okras na ramenu (npr. t. 4: 1,2; 5: 1-4), nekaj tudi na vratu (t. $6: 2 ; 7: 1 ; 9: 3)$. Okrašeni so še miniaturna skodela ( $t .12: 9)$, miniaturna steklenička ( $t .19$ : $4)$, keramična ploščica $z$ luknjo $(t$. 16: 10) in 5 odlomkov sten posod neopredeljenega tipa (npr. t. 13: 5,8). Preostali okrašeni keramični odlomki pripadajo skledam na nogah (3), skledam (1)

${ }^{23}$ Kramberger 2014a, 245, sl. 27-29; 32.
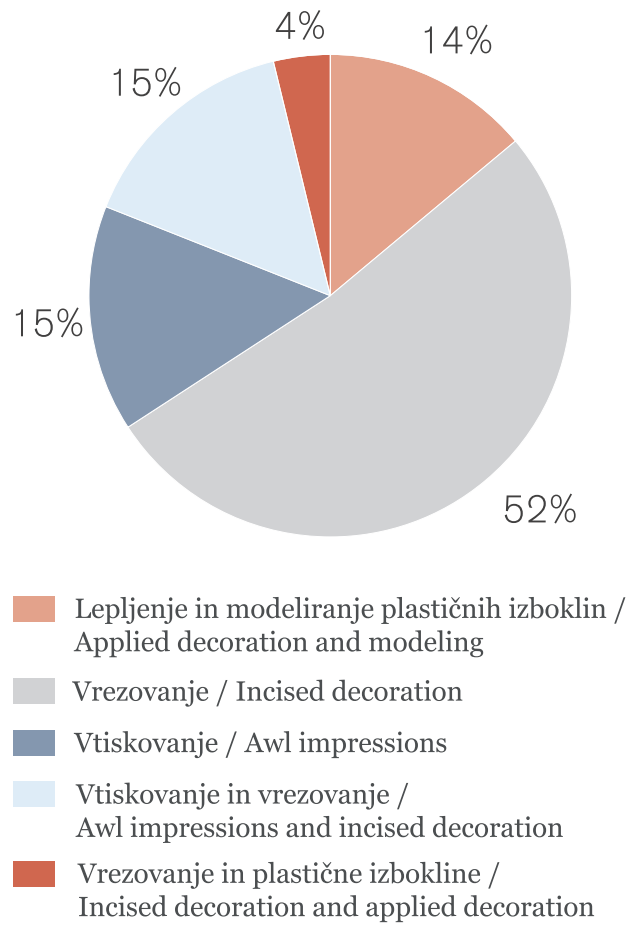

Sl. 7: Spodnje Hoče - Orglarska delavnica. Procentualna zastopanost različnih vrst okrasa na lončenini iz zgodnje bakrene dobe $(\mathrm{n}=81)$.

Fig. 7: Spodnje Hoče - Orglarska delavnica. Types of pottery decoration techniques from the Early Copper Age in $\%(\mathrm{n}=81)$.

in skodelam (8). Nekaj odlomkov z okrasom pa pripada bodisi skledam bodisi skodelam (npr. $t$. 17: 10). V tehniki vrezovanja je izdelana "delovna površina" pečatnika ( $t .16: 9)$.

Keramične posode so najpogosteje okrašene $z$ vrezovanjem ali v kombinaciji vrezovanja $z$ drugimi načini okraševanja, z izjemo skled (na nogah?) z visečimi jezičastimi nalepkami, ki so okrašene $\mathrm{v}$ tehniki apliciranja $(t .1: 1 ; 10: 1 ; 11: 5) . \mathrm{Z}$ aplikami so okrašeni še posamičen lonec $(t .19: 1)$, skodela (t. 11: 6), dve skledi (t. 20: 1; 21: 2), miniaturna skodela ( $t$. 12: 9) in trije tipološko neopredeljeni odlomki posod, od katerih sta dva predstavljena v katalogu (t. 13: 5; 21: 1).

Samo $\mathrm{z}$ vrezovanjem je okrašenih večina loncev (21) (t. 4: 2; 5: 2-4; 6: 1,2; 7: 2; 9: 3; 13: 9-15; 15: 2; 16: 1,2), vrčev (12) (t. 3: 6,8-10,13,14; 13: 1-3; 20: 4,7$)$ in skodel $(4)(t .1: 12 ; 2: 1,5,6)$ ter ena skleda ali skodela ( $t$. 2: 2). V kombinaciji tehnike vrezovanja in odtiskovanja je okrašenih 9 loncev (t. 7: 1,6,7; 9: $1 ; 14: 1,2 ; 16: 5)$, vrč $(t .13: 6)$ in dve skodeli ( $t .11: 11 ; 1: 10)$, v kombinaciji tehnike vrezovanja in apliciranja pa ena skleda $(t .18: 2)$ in dve skodeli (t. 2: 3,4). 
Manj pogost je vtisnjen okras. Tako je okrašenih še največ loncev (8) $(t .3: 15 ; 4: 1 ; 5: 1 ; 7: 3,4,5 ; 9$ : 2, 13: 7), pa tudi en vrč ( $t .3: 7)$, skleda ali skodela ( $t .17: 10)$, miniaturna steklenička ( $t .19: 4)$ in odlomek ostenja posode neopredeljenega tipa.

\section{Sklede}

Sklede so bile odkrite v zemljankah I (npr.t. 3: 1-5), II (npr. t. 11: 7-10; 12: 1-5,10) in III (npr. $t$. 17: $10 ; 18: 2)$ ter v jami II $(t .20: 1)$. Za večino je značilen navznoter nagnjen oziroma uvihan ( $t$. 3 : 1,5; 11: 9,10), navpičen (npr. t. 3: 3; 11: 8; 18:2) ali rahlo navzven nagnjen raven rob ustja (npr. $t$. 12: 5). Le pri eni skledi iz zemljanke II je bil rob ustja močno nagnjen navzven oziroma izvihan (t. 12: 1). Ta skleda se od ostalih razlikuje tudi po načinu izdelave, saj je imela tako na zunanji kot na notranji strani premaz rdeče barve (sl. 8: 3). Nagnjenost roba ustja se lahko pri skledah z ravnim robom tudi znotraj posamezne posode precej razlikuje (npr. t. 12: 4).

Za natančnejšo kronološko opredelitev se zdijo pomembnejši okras in dodatni elementi, ki se pojavljajo na robu ustja kot izlivi $(t .3: 2-4 ; 12: 3,4)$ ali paličasti držaji ( $t .11: 9 ; 18: 2)$. V enem primeru (skleda s koncentričnimi vrezi na obodu) je držaj ob prehodu v ostenje oblikovan $\mathrm{v}$ peterokrako zvezdo (t. 18: 2), podobno kot na skodeli z Brezja pod Brinjevo goro, ki je na ramenu okrašena $s$ snopi navpičnih vrezov in s plastično nalepko $\mathrm{v}$ obliki peterokrake zvezde. ${ }^{24}$

Več je skled, ki imajo izliv izvlečen ( $t$. 12: 4), v obliki dulca ( $t$. 3: 4) ali pa s pregrajo $(t .3: 2,3)$. Najbližje primerjave za sklede $\mathrm{z}$ izvlečenimi izlivi najdemo na lasinjskih najdiščih $\mathrm{v}$ Podravju, Dravinjskih goricah in na Raababergu. ${ }^{25} \mathrm{Na}$ teh najdiščih so znane tudi sklede $\mathrm{z}$ izlivi v obliki dulca (t. 3: 4). Veliko takih je bilo odkritih v bližnjem Zgornjem Radvanju, npr. v objektih 4 in 10, ki sta bila tudi radiokarbonsko datirana. Dve takšni posodi srečamo v zbiru z Raababerga pri Gradcu, po eno pa pod gomilo v Brezju pod Brinjevo goro ter v objektih I in IV z območja Šolskega centra

${ }^{24}$ Kramberger 2018, t. 6: 17.

25 Npr. Zgornje Radvanje v Mariboru (Kramberger 2014a, t. 7: 115; id. 2014b, t. 65: 715; 100: 1056; 105: 1102; 112: 1157; 157: 1524,1526; 162: 1552); Raababerg pri Gradcu (Obereder 1989, t. 15: 155-156); Hardek pri Ormožu (Žižek 2006b, najdba št. 20), Brezje pod Brinjevo goro - Podgraškova domačija (Kramberger 2018, t. 6: 12, verjetno tudi t. 6: 15).

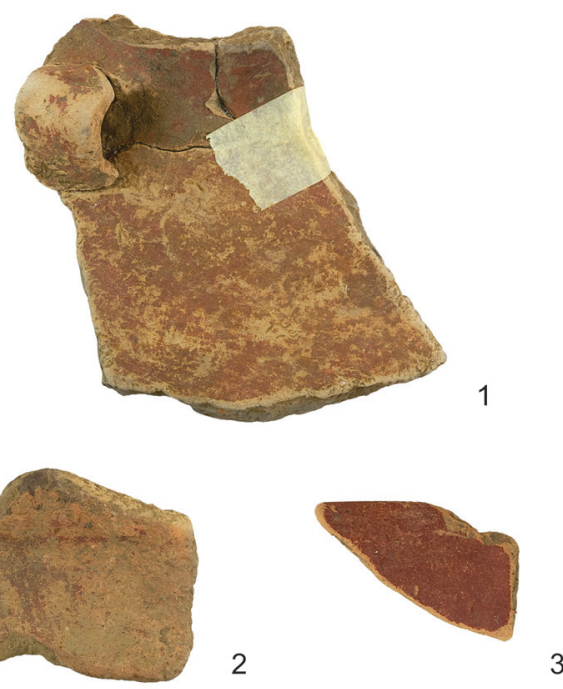

Sl. 8: Spodnje Hoče - Orglarska delavnica. Primeri keramike z rdečim premazom. 1 ( $t .8: 2), 2(t .1: 3), 3$ ( $t$. 12: 1). M. = 1:2.

Fig. 8: Spodnje Hoče - Orglarska delavnica. Examples of red-coated ceramics. 1 ( $P l .8: 2$ ), 2 (Pl. 1: 3), 3 (Pl. 12:1). Scale $=1: 2$.

na Ptuju. ${ }^{26}$ Primerek iz objekta IV, datiranega v razpon med drugo polovico 44. in prvo polovico 43. st. pr. n. št., ima dulec pod ustjem, enako kot skleda iz Zbelovega v Dravinjskih goricah. ${ }^{27}$

Sklede z izlivi s pregrajo ( $t .3: 2,3)$ se prav tako pojavljajo na štajerskih najdiščih lasinjske kulture, kjer so datirane v 45.-43. st. pr. n. št. ${ }^{28}$

Sklede $\mathrm{z}$ izlivi $\mathrm{v}$ obliki dulca in sklede $\mathrm{z}$ izlivi $s$ pregrajo pa srečamo tudi na nekoliko starejših najdiščih savske skupine. Skledo z izlivom v obliki dulca zasledimo v 4. poselitveni fazi Moverne vasi, okvirno datirani v 45. in prvo polovico 44 . st. pr. n. št. ${ }^{29} \mathrm{~V}$ ta čas sodijo tudi podobne sklede z navpičnim ali rahlo uvihanim ravnim robom

26 Zgornje Radvanje (Kramberger 2014a, t. 9: 143; 10: 154); Ptuj - Šolski center (Kramberger 2014b, t. 48: 549); Raababerg (Obereder 1989, t. 18: 183-185; 20: 200-202,206); Brezje pod Brinjevo goro - Podgraškova domačija (Kramberger 2018, t. 1: 11).

27 Ptuj - Šolski center, objekt IV (Kramberger 2014a, t. 5: 84); Zbelovo (V. Pahič 1983, t. 19: 1).

28 Zgornje Radvanje (Kramberger 2014a, t. 7: 111; 9: 145); Raababerg (Obereder 1989, t. 18: 188; 20: 205); Zbelovo (V. Pahič 1983, t. 11: 4); Ptuj - Šolski center, objekt I (Kramberger 2014b, t. 38: 436-437,440; 48: 545-547), objekt II (Kramberger 2014b, t. 28: 308-310, t. 31: 348) in objekt IV (Kramberger 2014a, t. 5: 91).

${ }_{29}$ Primerjava za posodo: Tomaž 1999, t. 17: 4. Glej tudi Budja 1992, sl. 4; Budja 1995, sl. 4. Za datacije 14C: npr. Sraka 2014, sl. 3. 
ustja in $\mathrm{z}$ izlivi s pregrajo, kot kažejo primerjave še $z$ drugih najdišč. ${ }^{30}$ Te posode so okrašene $z$ vtisnjenimi jamicami pod ustjem in na najširšem obodu ter s snopi vrezov na robu ustja. ${ }^{31}$

Ena izmed skled ali skodel iz Spodnjih Hoč ima rob ustja okrašen $z$ dvema nizoma vtisnjenih jamic (t. 17: 10), podobno kot primerki s Ptuja - Šolskega centra in Ptujskega gradu, iz Brezja pod Brinjevo goro, Rabensteina v Labotski dolini, Raababerga in Hodiškega jezera, pa tudi iz Drulovke na Gorenjskem. ${ }^{32}$ Tem najdiščem lahko dodamo še neolitsko-eneolitsko najdišče Wildoner Schlossberg, kjer podobno okrašeno in oblikovano skledo srečamo v četrtem oziroma prvem lasinjskem horizontu poselitve. ${ }^{33}$

Sklede $\mathrm{z}$ visečimi jezičastimi nalepkami na nogah so bile $\mathrm{v}$ Spodnjih Hočah ugotovljene $\mathrm{v}$ zemljankah I $(t .1: 1)$ in II $(10: 1,3,4,5 ; 11: 5)$ ter v jami II ( $t$. 20: 1), ena pa je brez podrobnejših najdiščnih podatkov ( $t$. 21:2). Med bolje ohranjenimi primerki sta prepoznavni dve obliki: skleda na nizki votli nogi $(t .10: 3)$ in skleda na visoki votli nogi z rahlo izbočenim zgornjim delom $(t$. 10: 5). Večina primerkov je bila izdelanih iz zelo finozrnatih glin in žganih nepopolno oksidacijsko z redukcijsko atmosfero v končni fazi $(t .1: 1 ; 10$ : 3-5; 11: 5 ; 20: 1), razen skleda iz neznanega konteksta (t. 21:2) in ena od skled $z$ visečo jezičasto nalepko iz zemljanke II ( $t$. 10: 1), ki sta bili nepopolno oksidacijsko žgani; površina sklede iz zemljanke II ima še premaz rdečerjave barve.

Sklede z navpičnim ali rahlo uvihanim robom ustja in visečimi jezičastimi nalepkami na najširšem obodu so kronološko občutljiva keramična obli-

\footnotetext{
${ }^{30}$ Primerjave za posodo: Ozalj - Stari grad (Težak-Gregl 2001, t. 4: 7); Moverna vas (Tomaž 1999, t. 19: 1; glej tudi Budja 1992, sl. 4; id. 1995, sl. 4); Ponikve pri Trebnjem (Ravnik, Tica 2018, G751). Datacije 14C: Moverna vas (Sraka 2014, sl. 3); Ponikve pri Trebnjem (Ravnik, Tica 2018, 77, sl. 123-124).

31 Prim. še Ptuj - Šolski center (Kramberger 2014b, t. 55: 635).

32 Rabenstein (Tiefengraber 2004, t. 7: 67,70; 14: 150); Raababerg (Obereder 1989, t. 12: 124-126; 13: 129,130); Hodiško jezero (Samonig 2003, t. 9: 98; 10: 99,102); Drulovka (Korošec 1960, t. 21: 7,10); Ptujski grad (Korošec 1956, t. 6: 1); Ptuj - Šolski center (npr. Kramberger 2014a, t. 6: 101); Brezje pod Brinjevo goro - Podgraškova domačija (Kramberger 2018, t. 5: 5-14; 6: 3-7,10,14,15); glej tudi Kramberger 2018, 79-81, sl. 10.

33 Tiefengraber 2018, sl. 189: 7.
}

ka, ki je na splošno značilna za lasinjsko kulturo zgodnjega eneolitika. ${ }^{34}$

\section{Votle noge posod}

Odlomki votlih nog so bili odkriti v zemljankah I ( $t .1: 2-9)$, II (t. 10: 2; 11: 1-4) in III (t. 17: 9). Večino primerkov predstavljajo visoke votle noge z rahlo izbočenim zgornjim delom $(t .1: 4 ; 11: 1,4$; 17: 9). Dve lahko opredelimo kot nizki votli nogi - ena je rahlo izbočena ( $t .1: 8)$, druga je ozka nizka stožčasta noga ( $t .11: 2)$. V zemljanki II pa je bila skleda $z$ uvihanim ravnim robom ustja in bolj cilindrično nizko votlo nogo (t. 10: 3).

Votle noge $\mathrm{z}$ rahlo izbočenim zgornjim delom se najpogosteje pojavljajo na lasinjskih najdiščih. ${ }^{35}$ So sestavni del posod, večina je verjetno pripadala skledam $z$ visečimi jezičastimi nalepkami na najširšem obodu, ki so bile izdelane iz zelo finozrnate lončarske mase in redukcijsko žgane. ${ }^{36}$

$\mathrm{Na}$ lasinjskih najdiščih srečamo tudi nizke in ozke nizke votle stožčaste noge. Primerjave za ozko nizko ( $t .11: 2)$ najdemo na štajerskih najdiščih in v Prekmurju. ${ }^{37}$ Nizko votlo stožčasto nogo (t. 10: 3) zasledimo na skledah preproste polkroglaste oblike z najdišč Col 1 pri Podgračenem in Ajdovska jama pri Krškem, ${ }^{38}$ fragmente brez ohranjenega zgornjega dela pa poznamo s prekmurskih in madžarsih najdišč. ${ }^{39} \mathrm{~V}$ savski skupini lengyelske kulture se pojavljajo na skledah s konkavno izvihanim robom ustja. ${ }^{40}$

${ }^{34}$ Glej npr. Guštin, Tomaž, Kavur 2005, 47; Velušček 2011a, 222, sl. 5.9.

35 Npr. Bukovnica (Šavel 2006, najdba št. 19); Popava 1 pri Lipovcih (Šavel, Karo 2012, najdba št. 38); Šafarsko (Šavel 1994, pril. 13: 10); Sodolek (Kavur, Tomaž, Mileusnić 2006, najdba št. 9); Ptujski grad (Korošec 1965, t. 14: 3); Ptuj - Šolski center (Kramberger 2014a, t. 6: 99; id. 2014b, t. 33: 356; 46: 535); Hajndl (Žižek 2006a, najdba št. 42); glej tudi Kramberger 2018, 87-89, sl. 14A.

${ }^{36}$ Npr. Dimitrijević 1961, t. 7: 45a; Kramberger 2014a, t. 5: 79; 9: 142,147; 10: 155.

37 Raababerg (Obereder 1989, t. 7: 75); Popava 1 pri Lipovcih (Šavel, Karo 2012, najdba št. 250); Šolski center (Kramberger 2014b, t. 26: 288-289).

${ }^{38}$ Horizont pokopovv Ajdovski jami: Mi. Horvat 2009, sl. 5: 1; Col 1 pri Podgračenem (Mi. Horvat 2005, sl. 10: 4).

39 Kalinovnjek pri Turnišču (Kerman 2013, najdba št. 135); Gorice pri Turnišču (Plestenjak 2010, najdba št. 51); Popava 1 pri Lipovcih (Šavel, Karo 2012, najdbe št. 25, 84, 262); Nagykanizsa-Inkey-Kápolna (Kalicz 2003, sl. 13: najdba št. 4).

${ }^{40}$ Npr. Tomaž 2010, najdbe št. 651, 1000, 274, 1058, 1123 , 1048; Budja 1995, sl. 4 (faza 5); Težak-Gregl 2001, t. 5: 1. 
Ob vnovičnem pregledu gradiva iz Spodnjih Hoč smo v keramičnem skupku iz zemljanke I prepoznali tudi odlomek noge s cilindričnim zgornjim delom in rdečim premazom $(t .1: 3 ; s l .8: 2)$, kakršne so značilne za najdišča, datirana $\mathrm{v}$ prvo polovico in začetek druge polovice 5. tisočletja pr. n. št., a se pojavljajo tudi $\mathrm{v}$ jamah $\mathrm{z}$ značilnim lasinjskim keramičnim gradivom na dolenjskih, gorenjskih in štajerskih najdiščih. ${ }^{41}$

\section{Skodele}

Skodele so bile v Spodnjih Hočah odkrite v zemljankah I ( $t$. $1: 10,12 ; 2: 1,3-6,9)$, II (t. 11: $6,11 ; 12: 6)$ in III $(t .18: 3,4)$; ena pa je iz neznanega konteksta ( $t .21: 3)$. Gre za nekoliko globlje bikonične posode $\mathrm{z}$ uvihanim robom ustja $(t .1$ : $10,12 ; 2: 4 ; 11: 6,11 ; 12: 6)$ ali $\mathrm{z}$ rahlo izbočenim ramenom (t. 2: 3,5,6,9).

Ena skodela $\mathrm{z}$ ravnim robom ustja ima na ustju držaj v obliki čepka $(t .18: 3)$, večina drugih ima ročaje $(t .1: 10,12 ; 2: 1 ; 11: 11 ; 21: 3$; morda tudi $t$. 18: 4). Na ramenih so lahko okrašene, največkrat s snopi vrezov ( $t .1: 12 ; 2: 1)$, včasih $\mathrm{v}$ kombinaciji s plastično nalepko (t. $2: 4)$ ali $\mathrm{z}$ vodoravnimi vtisnjenimi jamicami $(t .1: 10 ; 11: 11)$ ali zgolj s plastično nalepko ( $t$. 11: 6).

Skodela z držajem v obliki čepka iz zemljanke III ima primerjave predvsem na lasinjskih najdiščih v Prekmurju in na zahodnem Madžarskem. ${ }^{42}$ Posamično se pojavljajo še na Štajerskem, ${ }^{43}$ medtem ko jih iz Dolenjske in Gorenjske še ne poznamo.

Tudi skodele $z$ izbočenimi rameni so znane z lasinjskih najdišč. Krasijo jih snopi navpičnih vrezov $(t .2: 5,6)$, en primerek pa snopi navpičnih vrezov z okroglima plastičnima nalepkama $(t .2: 3)$. Ta kombinacija je redkeje zastopana na lasinjskih najdiščih v Prekmurju in na zahodnem Madžar-

${ }^{41}$ Kramberger 2018, 89-97; glej tudi Dolinar 2016, t. 11: 60; V. Pahič 1983, 97, t. 19: 6; Tiefengraber 2006, 233, najdba št. 3; Tomaž 2010, 28, sl 12 (desno); Kramberger 2014a, 240-242, sl. 11-12; t. 5: 80; 6: 96.

42 Popava 1 pri Lipovcih (Šavel, Karo 2012, najdbe št. 49, 239, 240, 506, 717, 729); Turnišče (Tomaž 2012, najdbe št. 435, 485, 487, 488); Kalinovnjek pri Turnišču (Kerman 2013, najdba št. 267); Dobri-Alsó-mező (Horváth, Katalin 2004, t. 6: 5); Sormás (Straub 2006, t. 5: 3; 8: 1-3); Gellénháza-Városrét (Horváth, Katalin 2003, t. 24: 2); Zalavár-Basasziget (Virág 2005, sl. 3: 5).

43 Zbelovo (V. Pahič 1983, t. 6: 3), Ormož - Škoršičev vrt (Tomanič-Jevremov, Tomaž, Kavur 2006b, najdba št. 7); Raababerg (Obereder 1989, t. 9: 97; 15: 153); Wildoner Schlossberg (Tiefengraber 2018, sl. 189: 10). skem. Podobne posode so znane iz pohorskega okoliša, Raababerga, Čakovca na Hrvaškem, na Dolenjskem pa v Ajdovski jami (v t. i. horizontu pokopov) in na Gradcu pri Mirni (v naselbinski jami z lasinjskim gradivom). ${ }^{44}$

\section{Lonci}

Kot lonce opredeljujemo večje posode $\mathrm{z}$ manjšo odprtino in ročaji $(t .3: 15 ; 4: 1,2 ; 5: 1-4 ; 6: 1-3$; 7: 1-8; 8: 1-5; 9: 1-4; 13: 7,9-15; 14:1-3; 15: 1-3; 16: $1,2,4,5 ; 18: 5,6 ; 19: 1-3,5 ; 20: 5,6,8)$. V celoti jih je bilo mogoče rekonstruirati sedem ( $t .4: 1,2$; 6: $2 ; 7: 6 ; 14: 3 ; 19: 3,5)$, dvanajst pa je ohranjenih od ustja do prehoda v konkavni ( $t .5: 1-3 ; 6: 1,3 ; 7$ : $8 ; 14: 1,2 ; 15: 1-3)$ ali zaobljen spodnji del (t. 20: 6). Razvrstimo jih lahko v dve skupini: na lonce $\mathrm{s}$ konkavnim spodnjim delom $\mathrm{z}$ rameni in vratom ter na sodčasto oblikovane lonce $\mathrm{z}$ zaobljenim ostenjem v spodnjem delu.

V zemljankah I in II v Spodnjih Hočah so prevladovali lonci s konkavnim spodnjim delom, rameni in vratom, ki se med seboj razlikujejo $\mathrm{v}$ oblikovanosti ramen in vratu ter $\mathrm{v}$ proporcionalnem razmerju med spodnjim in zgornjim delom posode.

Najpogostejši so lonci z dolgim konkavnim spodnjim delom, nizkimi zaobljenimi rameni in dolgim usločenim vratom ter lonci $\mathrm{z}$ dolgim konkavnim spodnjim delom, visokimi rameni in cilindričnim vratom. V zemljanki I je bilo odkritih sedem loncev $\mathrm{z}$ dolgimi usločenimi vratovi $(t .4: 1,2 ; 5: 1-3 ; 6$ : $1,2)$ in štirje s cilindričnimi $(t .6: 3 ; 7: 1,8 ; 8: 1)$, $\mathrm{v}$ zemljanki II pa dva lonca $\mathrm{z}$ dolgim usločenim vratom $(t .13: 7 ; 15: 1)$ in šest s cilindričnim $(t .14$ : $1-3 ; 15: 2,3 ; 16: 5)$. Spodnji del ostenja je običajno občutno daljši od zgornjega (npr. t. 6: 3; 7: 8; 14: $3)$, le pri enem rekonstruiranem loncu je ostenje $\mathrm{v}$ spodnjem delu posode približno enako visoko kot v zgornjem ( $t$. 7: 6).

Lonci s konkavnim spodnjim delom in cilindričnimi ali dolgimi usločenimi vratovi so pogosto okrašeni s snopi navpičnih ali rahlo poševnih plitvih žlebov ali vrezov na ramenu ( $t$. $5: 4 ; 7: 2$; 13: 9-15; 16: 1). Včasih je okras na prehodu v vrat dopolnjen $\mathrm{z}$ vodoravnim nizom vtisnjenih jamic (t. 14: 1,2), z enim ( $t .4: 2 ; 5: 2,3 ; 6: 1)$ ali dvema

44 Zgornje Radvanje (Kramberger 2010, t. 1: 6); Zbelovo (V. Pahič 1983, t. 10: 6); Brezje pod Brinjevo goro - Podgraškova domačija (Kramberger 2018, t. 6: 17); Raababerg (Obereder 1989, t. 14: 147), Čakovec (Dimitrijević 1961, t. 19: 136); horizont pokopov v Ajdovski jami (P. Korošec 1975, t. 13: 2); Gradec pri Mirni (Dular 2001, t. 2: 1). 


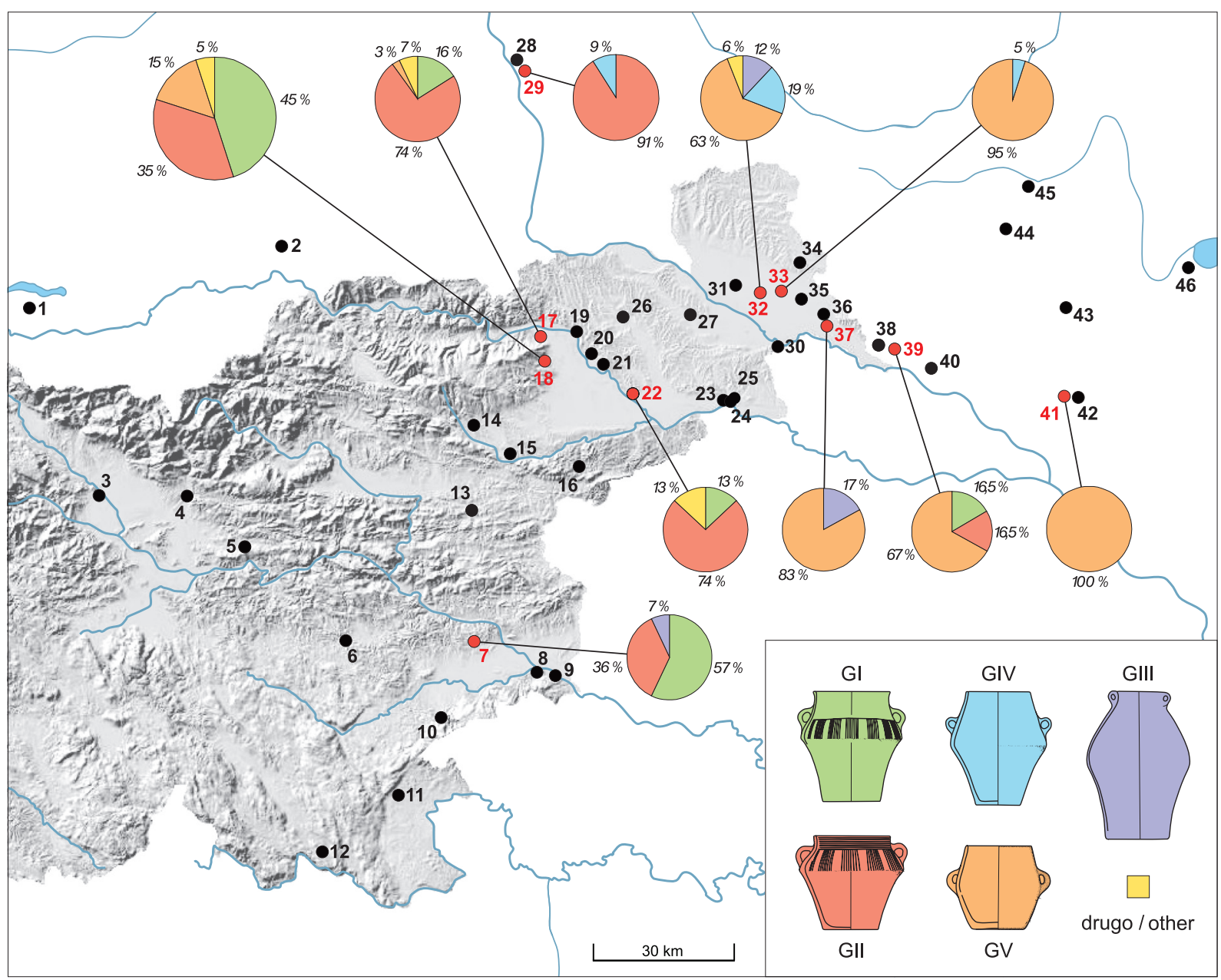

Seznam 1 (glej sl. 9) / List 1 (see Fig. 9)

1 - Keutschacher See [Samonig 2003].

2 - Rabenstein [Tiefengraber 2004].

3 - Drulovka; Kranj - Trubarjev trg [Korošec 1960; Dolinar 2016].

4 - Mali grad (Kamnik); Kratna (Kamnik) [Sagadin 2005; Velušček 2005].

5 - Gradišče (Dešen) [Pavlin, Dular 2007, 73-78].

6 - Gradec (Mirna) [Dular et al. 1991, 84-90; Dular 2001, 93, 95-96].

7 - Ajdovska jama (Nemška vas) [Šoberl et al. 2014; Mi. Horvat 2009; Ma. Horvat 1986; P. Korošec 1975].*

8 - Sredno polje (Čatež) [Tiefengraber 2006].

9 - Col 1 (Podgračeno) [Mi. Horvat 2005].

10 - Grac (Sela pri Zajčjem vrhu) [Pavlin 2006].

11 - Moverna vas [Budja 1992;1995; Tomaž 1999].

12 - Spaha (Brezovica pri Predgradu) [Velušček 2011b].

13 - Rifnik [Bolta 1962-1963].

14 - Zreče; Brezje [Pahič 1955; 1956].

15 - Zbelovo [V. Pahič 1983].

16 - Stoperce [Kramberger 2014a, 238-240].

17 - Zgornje Radvanje [Kramberger 2014b].*

18 - Hoče ${ }^{*}$

19 - Malečnik [Strmčnik Gulič 2006].

20 - Spodnji Duplek [Pahič 1976, 59-61].

21 - Vumpah (Vurberk) [Pahič 1976, 61-63].

22 - Ptuj [Kramberger 2014b].*
23 - Hajndl [Žižek 2006a].

24 - Ormož - Škoršičev vrt [Tomanič-Jevremov, Tomaž, Kavur 2006b].

25 - Hardek [Žižek 2006b].

26 - Spodnji Porčič [Pahič 1976, 61-63].

27 - Sodolek (Grabonoš) [Kavur, Tomaž, Mileusnić 2006].

28 - Kanzel (Graz / Gradec) [Artner et al. 2012].

29 - Raababerg (Graz / Gradec) [Obereder 1989; cf. Ruttkay 1993-1994].*

30 - Šafarsko [Šavel 1994, 30-39].

31 - Nova tabla (Murska Sobota) [Guštin et al. 2017].

32 - Popava 1 (Lipovci) [Šavel, Karo 2012].*

33 - Turnišče [Tomaž 2012; Plestenjak 2010; Kerman 2013].*

34 - Bukovnica [Šavel 1992].

35 - Brezje (Turnišče) [Novšak, Tomaž, Plestenjak 2013].

36 - Ivankovci (Lendava) [Tušek, Kavur 2011].

37 - Pri Muri (Lendava) [Šavel, Sankovič 2011].*

38 - Tornyiszentmiklós [Barna 2003].

39 - Dobri - Alsó-mező [Horváth, Katalin 2004].*

40 - Letenye - Szentkeresztdomb [Kalicz 1991].

41 - Sormás [Straub 2006].*

42 - Nagykanizsa-Sánc [Kalicz 1991].

43 - Zalaszentbalázs-Pusztatető [Bánffy 1995a, 36-40].

44 - Gellenhaza-Varosret [Horváth, Katalin 2003, 91,

219-224].*

45 - Zalaegerszeg-Andráshida [Horváth 2002].

46 - Zalavar-Basasziget [Virág 2005]. 
Opombe $k$ seznamu 1 / Notes to List 1:

*7: 14 prim. / pieces. - Šoberl et al. 2014 (sl. / Fig. 5: 02AJ,04AJ,60AJ,61AJ,68AJ); Mi. Horvat 2009 (sl. / Fig. 5: 6,7,9,11); Ma. Horvat 1986 (t. / Pl. 3: 1,2; 1: 3); P. Korošec 1975 (t. / Pl. 4: 4; 8: 1).

${ }^{\star}$ 17: 84 prim. / pieces. - Kramberger 2014b (t. / Pl. 56: 642; 57: 644; 58: 665,666; 59: 667,668; 61: 684,687; 62: 691,694; 63: 700; 66: 724; 68: 739,740; 69: 749; 70: 751; 73: 777; 74: 778-780; 75: 781-783; 76: 785; 82: 848; 83: 849,851; 84: 854,860; 85: 861,864; 89: 916; 92: 954,955,956; 93: 960; 96: 1018; 106: 1117,1120; 107: 1123; 109: 1133,1134; 112: 1163,1164; 115: 1187; 116: 1193; 120: 1223; 121: 1227; 122: 1228,1229,1232; 124: 1244; 127: 1273; 128: 1283; 129: 1288,1290; 130: 1298; 135: 1346,1347; 136: 1351,1353; 138: 1373; 140: 1389; 144: 1423,1424; 148: 1455; 149: 1459; 153: 1499; 154: 1500,1501; 155: 1506-1508; 159: 1534; 160: 1537,1538; 162: 1560; 164: 1575,1576; 165: 1588; 167: 1602; 169: 1617; 172: 1640; 174: 1657). ${ }^{\star}$ 18: Hoče; 20 prim. / pieces ( $t$. / Pl. 4: 1,2; 5: 1-3; 6: 1-3; 7: 6,8; 13: 7; 14:1-3; 15: 1-3; 19: 3,5; 20: 6).

*22: 15 prim. / pieces. - Kramberger 2014b (t. / Pl. 20: 234; 21: 252; 22: 253; 23: 260,261; 24: 266; 29: 323,324; 34: 389; 40: 475; 43: 501; 44: 502,503; 51: 582,585).

*29: 11 prim. / pieces. - Obereder 1989 (t. / Pl. 14: 146; 23: 247; 33: 335,336; 37: 369,377,379,380; 38: 390; 39: 397; 46: 465).

*32: 16 prim. / pieces. - Šavel, Karo 2012 (najdbe št. / Finds Nos. 115-118, 124, 371, 374-377, 446, 473, 478, 479, 480, 481).

*33: 20 prim. / pieces. - Tomaž 2012 (najdbe št. / Finds Nos. 7-14, 22-24, 26, 62, 63, 158, 199-201, 454, 456).

*37: 6 prim. / pieces. - Šavel, Sankovič 2011 (najdbe št. / Finds Nos. 5, 6, 92, 93, 131, 132).

*39: 6 prim. / pieces. - Horváth, Katalin 2004 (sl. / Figs. 9: 2; 19: 5; 24: 6; 25: 3,5,6).

*41: 5 prim. / pieces. - Straub 2006 (sl. / Fig. 4: 3-7).

$\leftarrow$

Sl. 9: Pomembnejša najdišča lasinjske kulture v Sloveniji, Avstriji in na zahodnem Madžarskem (glej seznam 1). Grafi prikazujejo odstotne deleže oblikovnih skupin loncev na posameznih najdiščih (rdeče št.).

Fig. 9: Major sites of Lasinja Culture in Slovenia, Austria and western Hungary (see List 1). The graphs show the percentages of different groups of pots at individual sites (red nos.).

vodoravnima žlebovoma/vrezoma $(t .7: 6 ; 15: 2)$. $\mathrm{V}$ posameznih primerih so vodoravni žlebovi segali vse do ustja (t. 6: 2; 9: 3), v enem primeru pa se zaključujejo $\mathrm{z}$ vodoravnim nizom vtisnjenih jamic (t. $7: 1)$.

Dva lonca s konkavnim spodnjim delom in dolgim usločenim vratom imata na ramenu snope vtisnjenih jamic (13: 7; 7: 5), pri dveh prekrivajo vtisnjene jamice celotno površino ramena $(t .7: 3,4)$, eden ima na prehodu $\mathrm{v}$ vrat dodan še vodoravni žleb ( $t$. 7: 7). Več loncev je na ramenih okrašenih $\mathrm{z}$ dvema vodoravnima nizoma vtisnjenih jamic (t. 3: 15; 4: 1 ; 5: 1; morda tudi t. 9: 2). Zasledimo še vodoravni vrez ( $t .16: 2)$, včasih $\mathrm{v}$ kombinaciji $\mathrm{z}$ vodoravnim nizom vtisnjenih jamic $(t .16: 5)$.

Da imajo lonci s cilindričnimi vratovi svoje predhodnike $\mathrm{v}$ loncih neolitske savske skupine, dokazujejo primerjave $\mathrm{z}$ najdišč iz 5 . tisočletja pr. n. št. na Slovenskem. Pri tem kaže poudariti, da sodita v okviru savske skupine edini doslej datirani najdišči s tako oblikovanimi lonci v najmlajši horizont/fazo, okvirno v 45. st. in prvo polovico 44. st. pr. n. št., ${ }^{45}$ medtem ko so lonci z najdišč

${ }^{45}$ Primerjave za lonce: Moverna vas 4 in 5 (Tomaž 1999, t. 22 : 1-3; 23: 1-2; 24: 1; 25: 1-2); Ponikve pri Trebnjem (Ravnik, Tica 2018, najdbe št. 1, 176-178, 181, 184, 749, 807); Drulovka (Guštin, Tomaž, Kavur 2005, najdbe št. 24-26; Korošec 1960, t. 9: 1; 19: 1; 22: 1,6,9); Ozalj - Stari grad (Težak-Gregl 2005, najdbe št. 17, 20, 22). Datacije 14C: Sraka 2014, sl. 3; Ravnik, Tica 2018, 77, sl. 123-124. savske skupine iz konca prve polovice 5. tisočletja pr. n. št. drugače oblikovani. ${ }^{46}$

Lonci s cilindričnim vratom, kot jih poznamo iz Spodnjih Hoč ( $t .6: 3 ; 7: 1,8 ; 8: 1 ; 14: 1-3 ; 15: 2,3$; 16: 5), se na Štajerskem in Dolenjskem pojavljajo na lasinjskih najdiščih. ${ }^{47}$

Na lasinjskih najdiščih s tega območja najdemo prav tako primerjave za lonce $s$ konkavnim spodnjim delom, nizkimi zaobljenimi rameni in dolgim usločenim vratom; pojavljajo pa se tudi na Gorenjskem na Drulovki pri Kranju. ${ }^{48}$

Pregledali smo zastopanost loncev s konkavnim spodnjim delom in dolgim usločenim vratom $(s l$. 9: GI) ter loncev s konkavnim spodnjim delom in

46 Npr. Kramberger 2014a, 248-253; Kramberger 2018a, 83

47 Zgornje Radvanje (npr. Kramberger 2014a, t. 8: 131, pril. 3; Kramberger 2014b, t. 58: 666; 69: 749; 75: 781-783; 84: 854; 96: 1018; 123: 1234; 128: 1283; 153: 1499); Šolski center (Kramberger 2014a, t. 5: 86, pril. 3; Kramberger 2014b, t. 20: 234; 22: 253); Ajdovska jama (Šoberl et al. 2014, sl. 5: 60 AJ); Col 1 pri Podgračenem (Mi. Horvat 2005, sl. 11: 17); Raababerg pri Gradcu (Obereder 1989, t. $23: 247 ; 32: 331 ; 33: 336 ; 37: 373-380 ; 39: 397)$.

48 Brezje pod Brinjevo goro - Podgraškova domačija (Kramberger 2018, t. 2: 8); Ajdovska jama (npr. Ma. Horvat 1986, t. 3: 1-2); Col 1 pri Podgračenem (Mi. Horvat 2005, najdba št. 18); Grac pri Selih pri Zajčjem vrhu (Pavlin 2006, najdbe št. 18, 20, 63); Drulovka pri Kranju (Guštin, Tomaž, Kavur 2005, najdba št. 23; glej tudi Korošec 1960, t. 19: $1 ; 22: 1,6,9 ; 24: 1,3 ; 30: 6)$. Glej tudi Kramberger 2018, 82-83, sl. 12 . 
cilindričnim vratom na lasinjskih najdiščih (sl. 9: GII). V skupini GI obravnavamo poleg loncev s konkavnim spodnjim delom, nizkimi rameni in dolgim usločenim vratom (npr. t. 4: 1,2; 5: 1-3; 6: $1,2)$ tudi njim podobne lonce s konkavnim spodnjim delom brez ramen in $\mathrm{z}$ dolgim usločenim vratom. V skupino GII pa so vključeni lonci s konkavnim spodnjim delom, rameni in cilindričnimi vratovi različnih dolžin. ${ }^{49}$

$\mathrm{V}$ analizo smo vključili lasinjska najdišča na ozemlju Slovenije, avstrijske Štajerske in zahodne Madžarske, s katerih je znanih najmanj pet loncev, ki imajo v zgornjem delu ohranjen celotni profil. Analiza je pokazala, da je takih najdišč malo (glej $s$. 9 in seznam 1). V primeru Šolskega centra na Ptuju smo v analizo vključili vse gradivo, kar pomeni, da bi lahko šlo deloma še za najdbe iz 45. st. pr. n. št. Iz Ajdovske jame pri Krškem smo upoštevali tudi lonec iz spodnje plasti v desnem hodniku, ki naj bi bila starejša od lasinjske kulture. ${ }^{50}$

Izkazalo se je, da v keramičnem zbiru z območja Orglarske delavnice v Spodnjih Hočah (sl. 9: 18) prevladujeta dva tipa loncev - GI z nizkimi rameni in dolgimi usločenimi vratovi (45\%) in GII s cilindričnimi vratovi (35\%). Enako je v Ajdovski jami (sl. 9: 7; GI - $57 \%$, GII - $36 \%$ ).

$\mathrm{V}$ bližnjem naselju v Zgornjem Radvanju ( $s$. 9: 17) prevladujejo lonci s konkavnim spodnjim delom, visokimi rameni in kratkim vratom (GII - $74 \%$ ), lonci s konkavnim spodnjim delom in dolgim usločenim vratom (GI - $16 \%$ ) so manj pogosti; podobno razmerje kaže Ptuj - Šolski center (sl. 9: 22; GI - $13 \%$, GII - $74 \%$ ). V Raababergu absolutno prevladujejo lonci $\mathrm{z}$ visokimi rameni in kratkimi cilindričnimi vratovi (sl. 9: 29; GII - $91 \%)$, medtem ko sta ta dva tipa loncev na lasinjskih najdiščih v Prekmurju (sl. 9: 32,33,37) in na zahodnem Madžarskem (sl. 9: 39,41) malodane neznana. ${ }^{51}$

Sodčasto oblikovani lonci oziroma z zaobljenim spodnjim delom in neizrazitim vratom, ki jih uvrščamo v skupino GV, so v Spodnjih Hočah zastopani s tremi neokrašenimi primerki; dva sta bila odkrita v zemljanki III in sta v celoti rekonstruirana (t. 19: 3,5), od tretje posode, najdene $\mathrm{v}$ jami II, je ohranjen le zgornji del $\mathrm{z}$ rameni in

49 Prim. Kramberger 2014a, t. 7: 122; 9: 146,153 ter t. 5: 86; 7: 114; 8: 131.

50 Ma. Horvat 1986, 82; Mi. Horvat 1989, 26-27; Velušček 2006, 29; prim. s Kramberger 2018, 83.

${ }^{51}$ Horváth, Katalin 2004, sl. 19: 5; 25: 5. ustjem ter zaobljenim prehodom $\mathrm{v}$ konveksni spodnji del ( $t$. 20: 6).

$\mathrm{V}$ nasprotju $\mathrm{z}$ lonci prve skupine sodčasto oblikovanih loncev na najdiščih savske skupine ne poznamo, so pa primerljive posode $\mathrm{z}$ najdišč pozne lengyelske kulture, torej skupine, ki je na prostoru zahodno od Slovenskih goric in zahodnem Madžarskem predhodnica lasinjske kulture. Eszter Bánffy jih uvršča v skupino posod, ki naj bi kazale na kontinuiran razvoj iz lengyelske $\mathrm{v}$ lasinjsko kulturo. ${ }^{52}$

Neokrašeni sodčasto oblikovani lonci se na lasinjskih najdiščih na obrobju Pohorja in v Halozah (sl. 9: 15,16) pojavljajo posamično, na pomurskih najdiščih so prevladujoča oblika loncev ( $s l$. 9: $32,33,37$ ), medtem ko na Dolenjskem in Gorenjskem doslej niso znani.

Več primerkov je znanih z lasinjskih najdišč na zahodnem Madžarskem (sl. 9: 39,41), posamezni pa tudi $\mathrm{z}$ avstrijskih in hrvaških lasinjskih najdišč. ${ }^{53}$

\section{Vrči}

Fragmente manjših posod $\mathrm{z}$ dolgim usločenim vratom, nizkimi rameni in presegajočim ročajem obravnavamo kot vrče $(t .3: 6-14 ; 13: 1-6 ; 20: 4,7)$. Izdelani so bili iz zelo finozrnate ali finozrnate gline in večinoma žgani nepopolno oksidacijsko z redukcijsko atmosfero v končni fazi $(t .3: 8,10 ; 13$ : $1-3,6 ; 20: 4,7)$, redkeje nepopolno oksidacijsko ( $t$. $3: 6,7,9 ; 13: 4)$. En nepopolno oksidacijsko žgan vrč ima na površini sledove rdečega premaza ( $t$. 13: 4), pet pa svetlikajočo se površino, ki je bila pred žganjem očitno spolirana $(t$. 3: 8,13,14; 13: 3,6).

Vrči so poleg loncev med posodami najpogosteje okrašeni - vseh 14 odlomkov z ohranjenimi rameni. Deset posod je okrašenih s snopi plitvih navpičnih žlebov ( $t$. 3: 6,8-10,13,14; 13: 1,2; 20: $4,7)$. V enem primeru so na ramenu vrča snopi plitvih žlebov in na prehodu v vrat vtisnjene jamice (t. 13: 6). Posamezno se pojavljajo kot okras še snopi skupin vtisnjenih jamic na ramenu ( $t .3: 7)$

52 Bánffy 1995b, 167-169, 171-174, 184, sl. 9.

${ }^{53}$ Glej tudi: Zalaszentbalázs-Pusztatető (Bánffy 1995a, 38-40, t. 32: 128,129); Nagykanizsa (Kalicz 1975, t. 9: 4; Kalicz 1991, sl. 8: 1); Zalaegerszeg-Andráshida (Horváth 2002, sl. 2: 13); Gellénháza-Városrét (Horváth, Katalin 2003, sl. 23: 8); Zalavár-Basasziget (Virág 2003, sl. 5: 4; 6: 4); Letenye-Szentkerszdomb (Kalicz 1973, sl. 19: 6); Tornyiszentmiklós (Barna 2003, sl. 6: 10); Kanzel pri Gradcu (Artner et al. 2012, t. 1: R30-R42+R69); Hodiško jezero (Samonig 2003, t. 8: 87); Jakšič (Marković 1985, 260, sl. 3). 
ter kombinacija snopov plitvih žlebov na ramenu in vodoravnih žlebov na prehodu v vrat ( $t$. 13: 3).

Tudi vrči sodijo med tipične posode lasinjske kulture. Primerku iz Spodnjih Hoč najdemo oblikovne in ornamentalne primerjave na štajerskih in dolenjskih najdiščih. ${ }^{54} \mathrm{Na}$ podobno oblikovanih posodah z lasinjskih najdišč v Prekmurju prevladuje motiv izmenjujočih se šrafiranih vrezanih trikotnikov, ${ }^{55}$ redkeje snopi žlebov na ramenih $(t$. 3: $6,8-10,13,14 ; 13: 1,2 ; 20: 4,7)$ in v kombinaciji z vodoravnim žlebom ( $t$. 13: 3) ali vtisnjenimi jamicami na prehodu v vrat $(t .13: 6) .{ }^{56}$

\section{Zajemalke}

Keramične zajemalke s predrtim nastavkom za držaj v obliki dulca so bile odkrite v zemljankah I (t. 9: 8-10), II (t. 16: 8) in III ( $t$. 19: 6). So srednje velikosti in večinoma slabše ohranjene, v celoti je bilo mogoče obnoviti le eno ( $t$. 9: 8 ). Dve sta brez bunčice ( $t$. 9: 8,9), ena ima bunčico na prehodu $\mathrm{v}$ recipient ( $t$. 16: 8 ), pri dveh slabše ohranjenih primerkih pa ni razvidno, ali sta jo imeli ali ne.

Zajemalke z bunčico naj bile bi značilne $\mathrm{za}$ epilengyelsko obdobje, kamor spada tudi lasinjska kultura. Starejšo obliko predstavljajo zajemalke brez bunčice na nastavku za držaj, ki se pojavljajo že na najdiščih lengyelske kulture in savske skupine. ${ }^{57}$

54 Zgornje Radvanje (npr. Kramberger 2014b, t. 62: 690; 64: 709; 66: 721; 80: 826,827; 81: 828-844; 91: 939,942-945; 96: 1017; 99: 1039,1041; 143: 1413,1414,1416,1421; 153: 1494-1497); Malečnik (Strmčnik Gulič 2006, najdba št. 17); Brezje - Podgraškova domačija (Kramberger 2018, t. 2: 3,6; 10: 19,24); Šafarsko (Šavel 1994, pril. 11: 13; 12: 25,36); Ajdovska jama (Mi. Horvat 2009, sl. 5: 12-14; ead. 1989, t. 1-8; 9: 469); Col 1 pri Podgračenem (Mi. Horvat 2005, sl. 11: 23,25,26); Grac pri Selih pri Zajčjem vrhu (Pavlin 2006, najdbe št. 24, 64); Čatež - Sredno polje, jama PO 004 (Tiefengraber 2006, najdbi št. 5,6).

55 Npr. Popava 1 pri Lipovcih (Šavel, Karo 2012, najdbe št. 90, 123, 153, 285, 287, 362, 372, 591, 670, 800, $803,808,809$ itd.).

56 Npr. Kalinovnjek pri Turnišču (Kerman 2013, najdba št. 248).

57 Ruttkay 1993-1994, 223; Kramberger 2018, 85. G. Tiefengraber objavlja tako oblikovano keramično zajemalko, okrašeno $\mathrm{z}$ vrezi in vtisnjenimi jamicami $\mathrm{z}$ najdišča Wildoner Schlossberg med gradivom horizonta II, datiranim na konec prve polovice 5. tisočletja pr. n. št. (Tiefengraber 2018, sl. 165: 31; sl. 169-172). Enako oblikovana in okrašena zajemalka je bila doslej znana $\mathrm{z}$ lasinjskega najdišča Raababerg (npr. Obereder 1989, t. 17: 173; Ruttkay 1993-1994, sl. 2: 4).

\section{Pekač}

Plitve posode - odlomek ( $t$. 18: 1), na katerem so ohranjeni zogleneli organski ostanki, je iz zemljanke III - uvrščamo med pekače. Dobro primerjavo najdemo v celotno ohranjenem primerku iz bližnjega Zgornjega Radvanja, ki ima na eni strani držaj in na notranji strani ožgano površino, kar dokazuje, da se je uporabljal kot pekač. ${ }^{58}$

Več pekačev poznamo tudi iz lasinjskega naselja Beketinci - Bentež na Hrvaškem. Ti so okrogle ali ovalne oblike, nekateri imajo na notranji strani utor - morda za mast. ${ }^{59}$

\section{Keramična ploščica $\mathrm{z}$ luknjo}

V zemljanki II je bila odkrita keramična ploščica $\mathrm{z}$ luknjo, okrašena s štirimi vzporednimi vrezi in glinenim premazom ( $t$. 16: 10). Videti je, da so jo izdelali iz posode, saj je na enem od robov ploščice še ohranjena originalna ravna površina ustja, morda skodele ali sklede.

Drugi robovi so bili zbrušeni po žganju. Zanimivo je, da je premaz ohranjen v sledovih tudi na stranskih robovih ploščice, zaradi česar lahko domnevamo, da je bil nanesen na površino, potem ko je bila posoda že žgana. Keramična ploščica bi lahko služila kot predilsko vretence ali kot obesek.

\section{Posoda z držajem v obliki človeške noge}

Posoda $z$ držajem v obliki človeškega stopala je bila po vsej verjetnosti odkrita v jami za stojko 7 med izkopavanji leta 1988 (t. 21: 1). Držaj je nameščen na zaobljenem ramenu posode, ki je bila v spodnjem delu konkavna.

Zoomorfno in antropomorfno oblikovani držaji posod so podrobneje obravnavani v prispevku o bakrenodobnih najdbah iz Brezja pod Brinjevo goro - Podgraškova domačija. Ugotovljeno je bilo, da se pojavljajo na lasinjskih najdiščih, in bi v njih lahko videli tradicijo sopotske kulture, saj se pojavljajo na najdiščih te kulture na Hrvaškem in Madžarskem. ${ }^{60}$

Držaju iz posode iz Spodnjih Hoč sta oblikovno najbližja primerka z najdišča Dobri - Alsó-mező na Madžarskem ter iz Kratne nad Kamnikom. V

58 Zgornje Radvanje (Kramberger 2014b, t. 134: 1331).

59 Beketinci - Bentež (Minichreiter, Marković 2013, t. $16: 1-4 ; 17: 1-4)$.

${ }^{60}$ Kramberger 2018, 86-87, sl. 13. 
navedenih primerih so namreč držaji v pogledu od spredaj bolj podolgovati in imajo po pet izrastkov (držaj iz Hoč morda šest), v njih pa bi lahko prepoznali upodobitve človeškega stopala. ${ }^{61}$

\section{Miniaturna steklenička}

Skoraj v celoti ohranjena miniaturna steklenička, ki ima odlomljena le ušesca na ustju (t. 19: 4), je bila odkrita v zemljanki III. Izdelana je bila iz zelo finozrnate gline in nepopolno oksidacijsko žgana, v končni fazi redukcijsko. Tik pod ustjem je okrašena s podolgovatimi vtisnjenimi jamicami. V višino meri $6,1 \mathrm{~cm}$, na najširšem obodu $3,8 \mathrm{~cm}$, premer odprtine pa znaša $0,9 \mathrm{~cm}$.

Miniaturne stekleničke s konkavno oblikovanim ostenjem $\mathrm{v}$ spodnjem in zgornjem delu ter z majhnimi perforiranimi držaji na ustju, včasih tudi na najširšem obodu, so znane predvsem $\mathrm{z}$ lasinjskih najdišč v Sloveniji in na sosednjem Hrvaškem; v literaturi so poimenovane tudi kot lasinjske stekleničke. ${ }^{62}$ Raziskovalci jih pripisujejo tradiciji tako imenovanih aryballoi, ki jih pozna kultura Vinča. ${ }^{63}$

\section{Valjasti pečatnik}

V Spodnjih Hočah je bil v zemljanki II odkrit pečatnik valjaste oziroma cilindrične oblike. Površino pečatnika $\mathrm{v}$ celoti prekrivajo vrezi, po motivu razporejeni $\mathrm{v}$ tri pasove - širok osrednji in po en ozek pas na vsakem koncu. Osrednjega krasi 17 gostih vzporednih vrezov, en zaključni pas ima kratke vreze, razporejene pravokotno na osrednji motiv, nasprotni zaključni pas krasijo snopi cikcak vrezov (t. 16: 9; sl. 10: 5). O pečatnikih je izšlo že več širših pregledov, med katerimi sta za jugovzhodni predalpski prostor pomembni deli J. Makkaya in O. Cornaggia Castiglionija. ${ }^{64}$ Pečatnike iz kontekstov kulture Kanzianiberg-

${ }^{61}$ Dobri-Alsó-mező (Horváth, Katalin 2004, t. 7: 15); Kamnik - Kratna (Velušček 2005, najdba št. 1).

62 Bolj znani primerki so npr. iz Ajdovske jame (Horvat, Horvat 1987, sl. 3; Mi. Horvat 2009, sl. 5: 16; P. Korošec 1975, t. 2: 10; 4: 7), Bukovja (Homen 1985, sl. 1) in najdišč Beketinec - Topolje (Homen 1985, sl. 2; 3), Ozalj - Špilja Vrlovka (Dimitrijević 1961, t. 17: 130), Cerje Tužno Krč (Marković 1994, t. 24: 9), Brezje nad Zrečami - pri Zimrajhovih (Pahič 1956, t. 1: 2) in Zgornje Radvanje (Kramberger 2014a, t. 7: 119).

63 Npr. Korošec 1958-1959; glej tudi Homen 1985; Težak Gregl 2007; Medović 2012.

${ }^{64}$ Cornaggia Castiglione 1956; Makkay 1984.
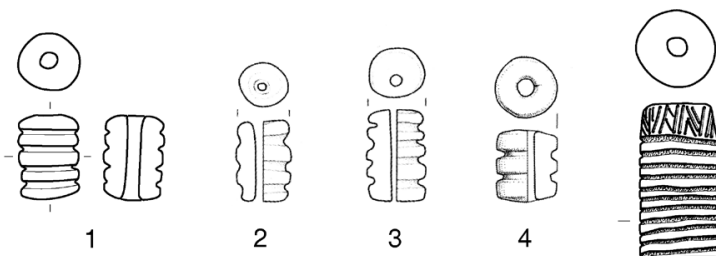

3

4
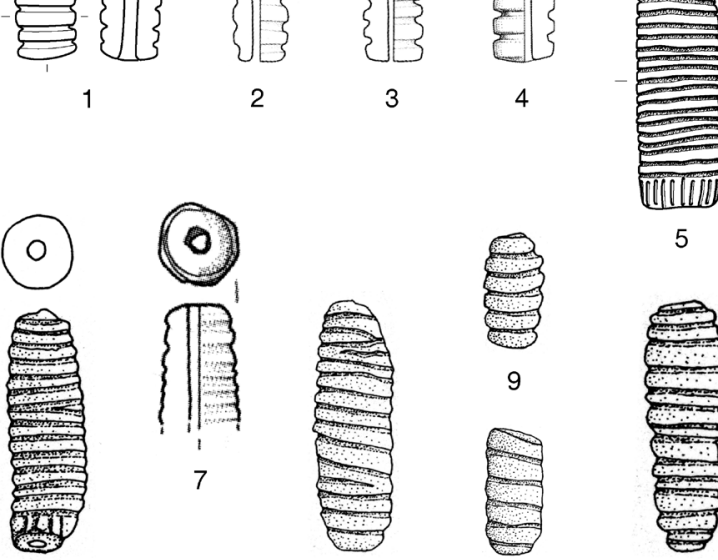

7

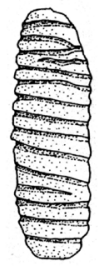

8

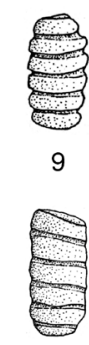

10
5

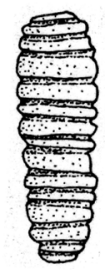

11

Sl. 10: Cilindrični pečatniki (različna merila).

Fig. 10: Cylinder seals (different scales).

1 Zgornje Radvanje (Kramberger 2014b, t. / Pl. 136: 1354); 2-3 Drulovka (Guštin, Tomaž, Kavur 2005, 51, najdbi št. / Finds Nos. 34, 35); 4 Spaha (Velušček 2011b, t. / Pl. 4.16: 12); 5 Hoče - Orglarska delavnica ( $t$. / Pl. 16: 9); 6 Notranje gorice (Harej 1976, t. / Pl. 4: 10); 7 Grac (Sela pri Zajčjem vrhu) (Pavlin 2006, 218, najdba št. / Find No. 55); 8-10 Caverna delle Arene Candide (Ruttkay 1993-1994, sl. / Fig. 4: 2-4); 11 Sitagroi (Ruttkay 1993-1994, sl. / Fig. 4: 7)

-Lasinja na avstrijskem Štajerskem je obravnavala Elisabeth Ruttkay in jih je opredelila v lasinjsko kulturo. Na osnovi širšega pregleda in primerjav je predpostavila, da ti pečatniki kažejo na medkulturne stike na dolge razdalje - na eni strani z območjem Balkana in na drugi s severno Italijo oz. Mediteranom. Pečatniki v obliki cigare, kot je poimenovala cilindrične primerke s prečnimi vrezi, naj bi bili najstarejša oblika v Evropi, znana v Liguriji (sl. 10: 8-10) in grški Makedoniji (sl. 10: 11) že okoli 5. tisočletja. V jugovzhodne Alpe naj bi se razširili v drugi polovici 5 . tisočletja iz sredozemskega prostora prek severne Italije. ${ }^{65}$

$S$ pečatniki s slovenskih najdišč se je podrobneje ukvarjal Miha Budja v članku, objavljenem leta 1992, v katerem je dotlej znane cilindrične primerke okvirno uvrstil $\mathrm{v}$ zaključek poznega neolitika. ${ }^{66}$ $\mathrm{V}$ oporo pri kronološki opredelitvi sta mu bila s spiralami okrašen cilindrični pečatnik, najden $\mathrm{v}$ Moverni vasi (v plasti SE 031; tj. 6. poselitvena faza), ki jo datira $v$ ta čas, ter glinen valj z luknjo $\mathrm{z}$

\footnotetext{
65 Ruttkay 1993-1994, 235-236.

${ }^{66}$ Budja 1992.
} 
Gradca pri Mirni, ki naj bi bil po "novi izkopavalčevi interpretaciji umeščen $\mathrm{v}$ fazo $1 \mathrm{~b}$ in artefaktni skupek 4".67 Tega je v primarni objavi Janez Dular opredelil v fazo III, kamor je uvrstil skupek najdb 8 iz najvišje bivalne površine, ki naj bi vseboval zelo pestre oblike posod in ornamentov, med njimi nekaj še klasičnih lasinjskih ornamentov kot tudi mlajših, značilnih za t. i. kulturo Retz-Gajary, česar niti v poznejši objavi ni spreminjal. ${ }^{68} \mathrm{Ob}$ tem kaže poudariti, da pri najdbi z Gradca pri Mirni manjka tisti najpomembnejši del, na podlagi katerega bi ga lahko zanesljivo opredelili kot pečatnik - to je okrašena pečatna površina. Sodeč po objavljeni risbi bi lahko šlo tudi za dulec keramične zajemalke ali za posebno obliko izliva. ${ }^{69}$

Pečatniku iz zemljanke II v Spodnjih Hočah je najbolj podoben primerek iz Notranjih Goric (sl. 10: 6), najden med izkopavanji W. Schmida. ${ }^{70}$ Datacija slednjega je prav tako negotova, saj je naselbina v Notranjih Goricah po mnenju raziskovalcev najverjetneje večfazna oziroma gre za več naselbin iz časa po lasinjski kulturi (horizonti Ljubljansko barje III-V in VII). Potemtakem bi bil pečatnik iz Notranjih Goric mlajši od tistega iz Hoč. Vendar podobnih pečatnikov z najdišč 4 . in 3. tisočletja na Slovenskem ne poznamo. ${ }^{71}$

Po okrasu na pečatni površini sta hoškemu primerku sorodna $\mathrm{v}$ celoti ohranjena pečatnika $s$ tremi oz. štirimi vzporednimi vrezi iz Drulovke pri Kranju (sl. 10: 2,3), vendar nimata znanih natančnejših najdiščnih podatkov. ${ }^{72}$ Nekateri avtorji ju uvrščajo med značilne najdbe savske skupine. ${ }^{73}$ Na Spahi pri Pregradu pa je bil odkrit podoben cel pečatnik z dvema vzporednima vrezoma ( $s l$. 10: 4) v premešani plasti (sonda 4; reženj 3; kv. 1) $\mathrm{z}$ veliko najdbami, ki kažejo na poseljenost $\mathrm{v}$ obdobju savske in lasinjske kulture do horizonta keramike $\mathrm{z}$ brazdastim vrezom. ${ }^{74}$

Glede datacije cilindričnih pečatnikov s slovenskih najdišč se lahko, kot se zdi, v tem trenutku opremo na primerke iz Moverne vasi, Zgornjega Radvanja, Hoč - Orglarske delavnice in Graca pri Selih pri Zajčjem vrhu. V Moverni vasi so uvrščeni v 6. poselitveno fazo, opredeljeno $\mathrm{v}$

67 Budja 1992, 104.

68 Dular et. al 1991, 87, 90, pril. 2A, t. 31: 9; prim. z Dular 2001, 93, 95-96, t. 3: 9,11.

${ }^{69}$ Prim. npr. Dular et al. 1991, t. 31: 14 ali npr. tu t. 3: 4.

70 Harej 1976, 104, t. 4: 10.

71 Parzinger 1984, sl. 7, t. 4.

72 Korošec 1960, t. 29: 3,4; Budja 1992, 95-99, 102-104.

73 Guštin, Tomaž, Kavur 2005, 51, najdbi št. 34, 35.

${ }^{74}$ Velušček 2011, 80, 81, 97, 98, 149; t. 4.16: 12. drugo polovico 44. in 43. st., kar potrjujejo tudi radiokarbonske datacije. ${ }^{75} \mathrm{~V}$ Zgornjem Radvanju je bil pečatnik (sl. 10: 1) najden $\mathrm{v}$ jami $\mathrm{z}$ značilno lasinjsko lončenino (v objektu 16; SE 929). ${ }^{76} \mathrm{Z}$ Graca pa izvira fragmentiran valjasti pečatnik, okrašen $\mathrm{v}$ ohranjenem delu s sedmimi vrezi $(s l$. 10: 7), najden je bil $\mathrm{v}$ plasti $\mathrm{z}$ menda homogenim keramičnim gradivom (sonda 1; plast 2). ${ }^{77}$

Čeprav so najdišča cilindričnih pečatnikov $\mathrm{z}$ območja Slovenije v objavah kulturno različno opredeljena, menimo, da so - z izjemo Notranjih Goric - njihovi keramični zbiri dokaj primerljivi in verjetno približno sočasni.

Zdi se pomembno poudariti, da cilindrični pečatniki za zdaj niso znani z najdišč, ki jih umeščamo na konec poznoneolitske savske skupine (4. in 5. poselitvena faza Moverne vasi; objekt II na Ptuj - Šolskem centru; najdišče Ponikve pri Trebnjem) in so radiokarbonsko datirana v 45. st. in prvo polovico 44. st., čeprav ne gre izključiti možnosti, da bi v ta čas lahko sodili pečatniki iz Drulovke in Spahe, kjer se mešajo najdbe savske skupine in lasinjske kulture. Zanesljivo pa jih ni na najdiščih savske skupine iz prve polovice 5 . tisočletja, kot so Resnikov prekop, Čatež - Sredno polje, Dragomelj in 2. poselitvena faza v Moverni vasi. ${ }^{78}$ Potemtakem lahko pojav cilindričnih pečatnikov na Slovenskem kronološko opredelimo v drugo polovico 5. tisočletja.

\section{KAMNITE NAJDBE}

Med kamnitimi najdbami z bakrenodobnega najdišča $\mathrm{v}$ Spodnjih Hočah so zastopani v celoti ohranjena kopača z luknjo ( $t$. 17: 5), ploščate sekire $(t .16: 14 ; 17: 1,7)$, odlomek rezila sekire $(t$. 9: 12), kamen $z$ delno navrtano luknjo ( $t .17: 3)$, izvrtki $(t$. 9: 11; 16: 11-13; 17: 4,6; 21: 4), žrmlje (t. 17: 2), tolkač (t. 20: 10) in brusni kamni (t. 21: $5,6)$, ki kažejo na različne vsakdanje aktivnosti. Žrmlje so pripomoček za ročno mletje žita ( $t$. 17:

\footnotetext{
75 Sraka 2014, sl. 3.

76 Glej Kramberger 2014b: pečatnik - t. 136: 1354; sklede $\mathrm{z}$ ravnim uvihanim robom ustja (t. 133: 1316,1318,1320,1326,1327; 143: 1329); odlomki votlih, v zgornjem delu izbočenih nog (t. 133: 1319,1321,1323); lonci (t. 135: 1346,1347; 136: 1350,1353); enoročajni vrči (t. 134: 1332,1334,1336,1337,1338); miniaturna steklenička (t. 136: 1349); pekač (t. 134: 1331).

77 Pavlin 2006, 213, najdba št. 55.

78 Kramberger 2014a, 248-253, sl. 35, 260; Ravnik,
} Tica 2018, 77, sl. 123-124. 
2), ${ }^{79}$ tolkači $(t .20: 10)$ za mečkanje ali drobljenje različnih snovi ali za izdelavo retuš na kamnitih orodij. Ostale kamnite najdbe bi lahko povezovali z obdelavo lesa in izdelavo glajenih kamnitih orodij, ki so bila uporabna za različna opravila.

Primerki ploščatih sekir se med seboj razlikujejo po velikosti in obliki. Sekira iz zemljanke II je bila oglata (t. 17: 1; ohr. dolž. 10,2 cm; šir. 4,9 cm; deb. $1,2 \mathrm{~cm}$;). Druga ploščata sekira je trikotne oblike in precej manjša (t. 17: 7; ohr. dolž. $4,5 \mathrm{~cm}$; šir. $4,2 \mathrm{~cm}$; deb. 0,54 cm). Po obliki in dimenzijah je primerljiva s tretjo sekiro, le da je ta na čelnem delu kot v predelu rezila širša $(t .16: 14$; dolž. 6,7 $\mathrm{cm}$; šir. 3,0-4,3 cm; deb. 1,4 cm). Ploščate sekire naj bi se uporabljale za obdelavo lesa, pri čemer so večje sekire $\mathrm{z}$ ozkim rezilom primernejše za sečnjo dreves, manjše $s$ širokim rezilom naj bi bile tesarske. Gre za pogoste naselbinske najdbe lasinjske kulture. Poznale so jih tudi različne druge eneolitske in neolitske kulture v Podonavju in na Balkanu. ${ }^{80}$

Kopača iz serpentinita iz Spodnjih Hoč ( $t$. 17: 5) je nekoliko drugačen tip glajenega kamnitega orodja. M. Lubšina Tušek jo je uvrstila med krajše, oglate, preluknjane kopače (vel. 10 do $15 \mathrm{~cm}$ in razmerjem med šir. in deb. $2: 1$ do $3: 1$ ). V njeni razčlenitvi kamnitega orodja $\mathrm{v}$ severovzhodni Sloveniji, ki temelji na tipološki členitvi S. Pahiča, spada v tip C2. Na Slovenskem predstavlja najštevilčnejšo različico kamnitega orodja, ki se je verjetno uporabljalo za kopanje gline, jam in morda v poljedelstvu. Pogosto se pojavljajo v Prekmurju in na Dravski ravnini, pa tudi na območju lasinjske kulture v sosednjih državah. ${ }^{81}$ Kopača $\mathrm{z}$ luknjo iz Spodnjih Hoč ( $t$. 17: 5$)$ je bila najdena s pripadajočim izvrtkom $(t .17: 4),{ }^{82}$ kar nedvomno kaže na to, da so sekiro izdelali na kraju samem. $\mathrm{Na}$ izdelovanje glajenega kamnitega orodja $\mathrm{v}$ naselju je mogoče sklepati tudi po drugih najdbah kamnitih izvrtkov brez pripadajočih sekir ( $t$. 9: 11; 16: 11-13; 17: 4,6; 21: 4), po brusnih kamnih $(t .21: 5,6)$ in kamnu $z$ delno navrtano luknjo $(t$. 17: 3), ki predstavlja nedokončano orodje, morda okroglo kladivo, kakršno so odkrili v Ormožu, Slovenski Bistrici, Tinju, Dolgi vasi, Veržeju, Seniku in Zamušanih. ${ }^{83}$

\footnotetext{
79 Turk 2009, 281-282.

${ }^{80}$ Lubšina Tušek 1993, 40-43, 46; tab. 2: E1,F2. Greif 1997-1998, 45-46.

${ }^{81}$ Lubšina Tušek 1993, 40-43, 49-50; tab. 2: C2; 24: 14.

82 Glej tudi Strmčnik Gulič 1996, 109-110, sl. 5.

${ }^{83}$ Lubšina Tušek 1993, 47, t. 12: 18; 25: 14,18; 5: 7; 7: $3 ; 11: 1$.
}

\section{SKLEP}

Analiza keramičnega gradiva je pokazala, da sodi bakrenodobno naselje $\mathrm{v}$ Hočah $\mathrm{v}$ lasinjsko kulturo. Iz tega obdobja je v severovzhodni Sloveniji znanih več kot 40 arheoloških najdišč, govorimo lahko o prvi intenzivni poselitvi prostora oziroma o "poselitvenem bumu", v nasprotju s poznim neolitikom, ko je znanih le peščica najdišč. ${ }^{84}$

Ugotavljamo, da je gradivu iz bakrenodobnega naselja v Hočah v oblikovnem in ornamentalnem smislu najbližje gradivo s sočasnih najdišč v Podravju in Dravinjskih goricah. Dobro je primerljivo tudi $z$ gradivom najdišč na Dolenjskem in Gorenjskem ter Raababerga pri Gradcu, predvsem v podobno oblikovanih in okrašenih loncih ter vrčih, skledah $\mathrm{z}$ rameni, $\mathrm{z}$ izlivi in na splošno $\mathrm{v}$ okrasni motiviki $\mathrm{s}$ snopi vrezov $\mathrm{v}$ kombinaciji $\mathrm{z}$ vodoravnimi nizi vtisnjenih jamic. $\mathrm{Na}$ omenjenih najdiščih so bili odkriti tudi enako okrašeni cilindrični pečatniki, ki jih nekateri raziskovalci interpretirajo kot odsev kontaktov na velike razdalje. ${ }^{85}$

Videti je, da ima lončenina na lasinjskih najdiščih v Podravju, Dravinjskih goricah in v jugovzhodni Sloveniji predhodnike na najdiščih pozne savske skupine, datiranih v 45. st. in prvo polovico 44 . st. pr. n. št. To se kaže predvsem v oblikovanosti loncev s cilindričnimi vratovi, skled $\mathrm{z}$ izlivi v obliki dulca ali s pregrajo ter vizdelavi okrasa in motiviki.

Nekoliko manj skupnih točk je med bakrenodobnim gradivom iz Hoč in gradivom $\mathrm{z}$ najdišč $\mathrm{v}$ Prekmurju. Povezave s tem prostorom izkazujejo predvsem sodčasto oblikovani lonci in skodele $\mathrm{z}$ gumbastimi držaji na ustju iz zemljanke III, ki so najpogostejši na lasinjskih najdiščih v Pomurju in zahodnem Madžarskem, kar v primeru loncev potrjuje tudi statistična analiza. Pri tem je zanimivo, da se sodčasti lonci na Madžarskem prvič pojavijo v pozni lengyelski kulturi, izvor pa naj bi imeli na prostoru osrednjega Balkana. ${ }^{86} \mathrm{Od}$

${ }^{84}$ Najpomembnejši najdišči pozne lengyelske kulture sta Andrenci (Pahič 1973; id. 1976, 31-59) in Bukovnica (Šavel 1992, 59-60; ead. 1994, 47-48; ead. 2006, 90), njima sočasno je bilo Stoperce - jama SE 128, ki se uvršča v savsko skupino lengyelske kulture (Kramberger 2014a, 247-250). V pozni neolitik je bilo opredeljenih še nekaj najdb s Ptujskega gradu (Tomanič-Jevremov, Tomaž, Kavur 2006a, 176-178). Deloma vzporeden z mlajšo fazo savske skupine pa je bil Ptuj - Šolski center (Guštin 2005, 13, sl. 1; Kavur 2010, 71; Kramberger 2014a, 260, sl. 35).

${ }^{85}$ Ruttkay 1993-1994, 235-236.

86 Bánffy 1994, 293; Bánffy 1995b, 168, sl. 9: spodnje tri posode; t. 65 : 135; 84: 40. 
tam naj bi se razširili tudi okrogli držaji na ustjih skled in skodel. ${ }^{87}$

$\mathrm{V}$ času "poselitvenega buma" v drugi polovici 5. tisočletja oz. na prehodu $\mathrm{v}$ bakreno dobo je $\mathrm{v}$ izdelavi lončenine lasinjske kulture $\mathrm{v}$ severovzhodni Sloveniji mogoče videti prepletanje različnih lončarskih tradicij - na eni strani savske skupine, ki je izrazitejša na najdiščih v Podravju in Dravinjskih goricah, na drugi lengyelske kulture - ter vplive s prostora osrednjega Balkana, ki so opaznejši na lončenini $\mathrm{z}$ najdišč v Prekmurju.

Podobno dvojnost $v$ materialni kulturi opažamo že na koncu prve polovice 5. tisočletja, kar odseva razprostranjenost lengyelske kulture in potreba po definiciji savske skupine lengyelske kulture, ki je nedvomno segala tudi v severovzhodno Slovenijo, to zlasti dokazuje najdišče Stoperce v Halozah. ${ }^{88}$

O konkretnih razlogih za izrazito povečanje števila najdišč v drugi polovici 5. tisočletja $\mathrm{v}$ severovzhodni Sloveniji je na osnovi dosedanjih raziskav verjetno še preuranjeno govoriti. Očitno pa je, da se "poselitveni bum" časovno ujema s t. i. metalnim bumom oziroma širjenjem poznavanja metalurgije iz jugovzhodne Evrope. ${ }^{89}$ Iz teh raziskav izhaja, da moramo tudi prehod $\mathrm{v}$ eneolitik v severovzhodni Sloveniji dojemati kot serijo postopnih sprememb in $\mathrm{v}$ povezavi $\mathrm{z}$ zapletenimi interakcijami med različnimi prazgodovinskimi skupnostmi, ki bi lahko vključevale tudi prihod ljudi od drugod.

\section{Zahvala}

Zahvaljujem se Miri Strmčnik Gulič, vodji arheološkega izkopavanja, ker mi je omogočila dostop do bakrenodobnega gradiva iz Spodnjih Hoč in prijazno dovolila objavo. Za posredovanje terenske dokumentacije gre zahvala Miheli Kajzer Cafnik, Stanku Gojkoviču pa za pomoč pri fizičnem prenosu najdb.

87 Horváth 1996, 338-339.

${ }^{88}$ Npr. Pahič 1973, 18-21, t. 3: E; Pahič 1976, 31-59, t. 6: 8,13; Šavel 1992, 59-60, t. 3: 4,5; Šavel 1994, 47-48, pril. 18: 16,17; ead. 2006, 90; Guštin 2005a, 10; Velušček 2011a, 222, sl. 5.8; Kramberger 2014a, 247-250.

${ }^{89}$ Npr. Banffy 1995b, 184-185.

\section{KATALOG}

Večino najdb iz bakrenodobnega naselja v Spodnjih Hočah hrani ZVKDS, OE Maribor. Pečatnik (t. 16: 9) in miniaturna steklenička (t. 19: 4) sta $\mathrm{v}$ Pokrajinskem muzeju Maribor. V knjižnici v Hočah so razstavljeni: odlomek posode $\mathrm{z}$ držajem v obliki človeškega stopala $(t .21: 1)$, rekonstruirana keramična zajemalka ( $t$. 9: 8), skleda $\mathrm{z}$ izlivom $(t$. 12: 4), odlomek sklede $\mathrm{z}$ dvema jezičastima aplikama ( $t$. 21: 2), eden od kamnitih izvrtkov ( $t .17$ : $4)$, dve kamniti sekiri ( $t .17: 5,7)$, kamniti tolkač iz serpentinita ( $t .20: 10)$, kamen z delno navrtano luknjo $(t .17: 3)$, dva večja $(t .21: 5,6)$ in en manjši fragment brusnega kamna.

\section{Tabla 1}

1. Skleda (na nogi?) - odl. ustja $z$ ostenjem in visečo jezičasto apliko na najširšem obodu, izdelana iz zelo finozrnate gline, nepopolno oksidacijsko žgana, v končni fazi redukcijsko. Površina gladka in sive barve, na njej lise zelo bledo rjave barve; delno izprana. Okras je izdelan v osnovni tehniki apliciranja (viseča jezičasta nalepka). Zemljanka I (1989); št. risbe: H171.

2. Odl. noge posode (sklede?), izdelane iz zelo finozrnate gline, nepopolno oksidacijsko žgane, v končni fazi redukcijsko. Površina gladka in lisasta, zelo temno sive in temno sive barve; delno izprana. Zemljanka I (1989); št. risbe: $\mathrm{H} 176$.

3. Odl. zgornjega dela noge posode (sklede?), izdelane iz finozrnate gline, nepopolno oksidacijsko žgane. Površina gladka, svetlo rjave barve, na njej premaz rdeče barve; delno izprana. Zemljanka I (1989); št. risbe: H2019. (Sl. 8: 2).

4. Odl. dna z zgornjim delom noge posode (sklede?), izdelane iz zelo finozrnate gline, nepopolno oksidacijsko žgane, v končni fazi redukcijsko. Površina gladka, temno sive barve, na njej lise sive in svetlo rdeče barve; delno izprana. Zemljanka I (1989); št. risbe: H148.

5. Odl. noge posode (sklede?), izdelane iz zelo finozrnate gline, nepopolno oksidacijsko žgane, v končni fazi redukcijsko. Površina sive barve, na notranji strani gladka in mat, na zunanji deloma svetlikajoča, spolirana; delno izprana. Zemljanka I (1989); št. risbe: H150.

6. Odl. roba noge posode (sklede?), izdelane iz zelo finozrnate gline, nepopolno oksidacijsko žgane, v končni fazi redukcijsko. Površina sive barve, na notranji strani noge groba, na zunanji gladka; delno izprana. Zemljanka I (1989); št. risbe: H128.

7. Odl. roba noge posode (sklede?), izdelane iz zelo finozrnate gline, nepopolno oksidacijsko žgane, v končni fazi redukcijsko. Površina gladka, temno sive barve. Zemljanka I (1989); št. risbe: H186.

8. Odl. dna $z$ nogo posode, verjetno sklede, izdelane iz zelo finozrnate gline, nepopolno oksidacijsko žgane. Površina gladka in lisasta, zelo bledo rjave in sive barve; delno izprana. Zemljanka I (1989); št. risbe: H177.

9. Odl. roba noge posode (sklede?), izdelane iz zelo finozrnate gline, nepopolno oksidacijsko žgane. Površina 
gladka in lisasta, svetlo rdeče in sive barve. Zemljanka I (1989); št. risbe: H131.

10. Skodela - odl. ustja z ostenjem in prehodom v ročaj, zdelana iz zelo finozrnate gline, nepopolno oksidacijsko žgana, v končni fazi redukcijsko. Površina gladka in lisasta, sive in temno sive barve. Tik pod ustjem okrašena $\mathrm{z}$ vodoravnim nizom vtisnjenih jamic, med najširšim obodom in ustjem s snopi plitvih navpičnih žlebov in v praznem vmesnem prostoru $\mathrm{z}$ dvema vodoravnima nizoma vtisnjenih jamic. Zemljanka I (1989); št. risbe: H157.

11. Odl. roba keramičnega predmeta (posode?), izdelanega iz zelo finozrnate gline, nepopolno oksidacijsko žganega. Površina gladka in lisasta, bledo rjave in sive barve. Odl. roba je perforiran. Zemljanka I (1989); št. risbe: H130.

12. Skodela - odl. ustja $z$ ostenjem in prehodom v ročaj. Izdelana iz zelo finozrnate gline, nepopolno oksidacijsko žgana, v končni fazi redukcijsko. Površina gladka, temno sive barve; delno izprana. Med najširšim obodom in ustjem okrašena s snopi poševnih žlebov v cikcaku. Zemljanka I (1989); št. risbe: H110.

\section{Tabla 2}

1. Skodela - odl. ustja z ostenjem in ročajem, izdelana iz zelo finozrnate gline, nepopolno oksidacijsko žgana, $\mathrm{v}$ končni fazi redukcijsko. Površina gladka in sive barve. Med najširšim obodom in ustjem okrašena s snopom plitvih poševnih žlebov. Zemljanka I (1989); št. risbe: H156.

2. Odl. ustja $z$ ostenjem sklede ali skodele, izdelane iz finozrnate gline, nepopolno oksidacijsko žgane. Površina gladka, lisasta - svetlo rjave, rjave in sive barve. Med najširšim obodom in ustjem okrašena s snopom navpičnih žlebov. Zemljanka I (1989); št. risbe: H183.

3. Skodela - odlomka ustja $\mathrm{z}$ ostenjem, izdelana iz zelo finozrnate gline, nepopolno oksidacijsko žgana, v končni fazi redukcijsko. Površina gladka in sive barve; delno izprana. Med najširšim obodom in ustjem okrašena s snopi navpičnih žlebov in z okroglima nalepkama. Zemljanka I (1989); št. risbe: H133.

4. Skodela - odl. ustja z ostenjem, izdelana iz zelo finozrnate gline, nepopolno oksidacijsko žgana. Površina gladka, zelo bledo rjave barve, na njej svetlo rdeč premaz; delno izprana. Med najširšim obodom in ustjem okrašena s snopom navpičnih žlebov in z okroglo nalepko. Zemljanka I (1989); št. risbe: H134.

5. Skodela - odl. ustja z ostenjem, izdelana iz zelo finozrnate gline, nepopolno oksidacijsko žgana, v končni fazi redukcijsko. Površina gladka, mestoma svetlikajoča se (spolirana) in lisasta, temno sive in sive barve; delno izprana. Na ramenih okrašena s snopom poševnih žlebov. Zemljanka I (1989); št. risbe: H118.

6. Skodela - odl. ustja $\mathrm{z}$ ostenjem, izdelana zelo finozrnate gline, nepopolno oksidacijsko žgana, v končni fazi redukcijsko. Površina gladka, temno sive barve; delno izprana. Okrašena s plitvimi navpičnimi žlebovi. Zemljanka I (1989); št. risbe: H185.

7. Odl. ustja $z$ ostenjem sklede, izdelana iz zelo finozrnate gline (LM07), nepopolno oksidacijsko žgana, v končni fazi redukcijsko. Površina gladka in sive barve. Zemljanka I (1989); št. risbe: H135.
8. Miniaturna skodela - odlomka ustja z ostenjem, izdelana iz zelo finozrnate gline, nepopolno oksidacijsko žgana. Površina groba in lisasta, rožnate, zelo bledo rjave in sive barve. Zemljanka I (1989); št. risbe: H124.

9. Skodela - odl. ustja $\mathrm{z}$ ostenjem, izdelana iz zelo finozrnate gline, nepopolno oksidacijsko žgana, v končni fazi redukcijsko. Površina gladka, lisasta, temno sive in sive barve; delno izprana. Zemljanka I (1989); št. risbe: H109.

10. Odl. ustja $z$ ostenjem sklede ali skodele, izdelana iz finozrnate gline, nepopolno oksidacijsko žgana. Površina groba in lisasta, bledo rjave, sive in temno sive barve; delno izprana. Zemljanka I (1989); št. risbe: H117.

\section{Tabla 3}

1. Skleda - odl. ustja z ostenjem, izdelana iz zelo finozrnate gline, nepopolno oksidacijsko žgana. Površina gladka, lisasta, rožnate in sive barve; delno izprana. Zemljanka I (1989); št. risbe: H112.

2. Skleda - odl. ustja z ostenjem in izlivom, izdelana iz finozrnate gline, nepopolno oksidacijsko žgana. Površina gladka, lisasta, svetlo rjave in temno sive barve; delno izprana. Zemljanka I (1989); št. risbe: H221.

3. Skleda $z$ izlivom (rekonstruirana), izdelana iz finozrnate gline, nepolno oksidacijsko žgana. Površina gladka in lisasta, bledo rjave in sive barve. Zemljanka I (1989); št. risbe: $\mathrm{H} 163$.

4. Skleda - odl. ustja $\mathrm{z}$ ostenjem in izlivom, izdelana iz finozrnate gline, nepopolno oksidacijsko žgana. Površina gladka, lisasta, zelo bledo rjave in sivo rjave barve; delno izprana. Zemljanka I (1989); št. risbe: H132.

5. Skleda - odl. ustja z ostenjem, izdelana iz finozrnate gline, nepopolno oksidacijsko žgana. Površina gladka in lisasta, zelo bledo rjave in sive barve. Zemljanka I (1989); št. risbe: $\mathrm{H} 129$.

6. Vrč - odl. ostenja, izdelan iz zelo finozrnate gline, nepopolno oksidacijsko žgan. Površina gladka, lisasta, svetlo rjave, zelo bledo rjave in sive barve; delno izprana. $\mathrm{Na}$ ramenih okrašena s snopi plitvih navpičnih žlebov. Zemljanka I (1989); št. risbe: H154.

7. Vrč - odl. ostenja, izdelan iz finozrnate gline, nepopolno oksidacijsko žgan. Površina gladka, lisasta, svetlo rjave in rožnate barve. Na ramenih okrašena s snopi iz vtisnjenih jamic. Zemljanka I (1989); št. risbe: H161.

8. Vrč - odl. ostenja, izdelan iz zelo finozrnate gline, nepopolno oksidacijsko žgan, redukcijsko v končni fazi. Površina je lisasta, sive in temno sive barve; delno svetlikajoča se (spolirana), delno izprana. $\mathrm{Na}$ ramenih okrašena s snopom navpičnih žlebov. Zemljanka I (1989); št. risbe: $\mathrm{H} 119$.

9. Vrč - odl. ostenja s prehodom v ročaj, izdelan iz finozrnate gline, nepopolno oksidacijsko žgan. Površina gladka, lisasta, rožnate, zelo bledo rjave in sive barve; delno izprana. Na ramenih okrašena s snopi navpičnih žlebov. Zemljanka I (1989); št. risbe: H175.

10. Vrč - odl. ostenja, izdelan iz zelo finozrnate gline, nepopolno oksidacijsko žgan $\mathrm{z}$ redukcijsko atmosfero $\mathrm{v}$ končni fazi. Površina gladka in sive barve; delno izprana. Okras je izdelan v osnovni tehniki vrezovanja (pravi vrez). 
Na ramenih okrašena s snopi navpičnih žlebov. Zemljanka I (1989); št. risbe: H120.

11. Odl. ostenja posode, izdelane iz zelo finozrnate gline, nepopolno oksidacijsko žgane. Površina gladka, lisasta, bledo rjave in sivo rjave barve. Zemljanka I (1989); št. risbe: $\mathrm{H} 152$.

12. Vrč - odl. ostenja in odl. ostenja z ročajem, izdelan iz zelo finozrnate gline, nepopolno oksidacijsko žgan, v končni fazi redukcijsko. Površina gladka, temno sive barve; delno izprana. Zemljanka I (1989); št. risbe: H172.

13. Vrč - odl. ostenja s prehodom v ročaj in odl. dna $\mathrm{z}$ ostenjem, izdelan iz zelo finozrnate gline, nepopolno oksidacijsko žgan, v končni fazi redukcijsko. Površina je lisasta, temno sive in sive barve; delno izprana, delno svetlikajoča se (spolirana). Na ramenih okrašena s snopi rahlo poševnih žlebov. Zemljanka I (1989); št. risbe: H140.

14. Vrč - odl. ostenja, izdelan iz zelo finozrnate gline, nepopolno oksidacijsko žgan, v končni fazi redukcijsko. Površina temno sive barve, na notranji strani gladka in mat, na zunanji gladka in svetlikajoča se (spolirana); delno izprana. Na ramenih okrašena s snopi navpičnih žlebov. Zemljanka I (1989); št. risbe: H126.

15. Lonec - odlomka ostenja, izdelan iz zelo finozrnate gline, nepopolno oksidacijsko žgan. Površina gladka, rdeče barve. $\mathrm{V}$ spodnjem delu ramen okrašena $\mathrm{z}$ dvema vodoravnima nizoma vtisnjenih jamic. Zemljanka I (1989); št. risbe: $\mathrm{H} 122$.

\section{Tabla 4}

1. Lonec (rekonstruiran), izdelan iz zelo finozrnate gline, nepopolno oksidacijsko žgan. Površina je lisasta zelo bledo rjave, rožnate, svetlo rjavo sive, temno sive in sive barve, na notranji strani groba, na zunanji gladka; delno izprana. $\mathrm{Na}$ ramenih okrašena $\mathrm{z}$ dvema vodoravnima nizoma vtisnjenih jamic. Zemljanka I (1989); št. risbe: H178.

2. Lonec (rekonstruiran), izdelan iz zelo finozrnate gline, nepopolno oksidacijsko žgan. Površina je lisasta, svetlo rjave, rožnato sive in sive barve, na notranji strani posode groba, na zunanji gladka; delno izprana. Po celotni površini ramen okrašena s snopi navpičnih žlebov, na prehodu v vrat z vodoravnim žlebom. Zemljanka I (1989); št. risbe: $\mathrm{H} 226$.

\section{Tabla 5}

1. Lonec - odl. ustja $\mathrm{z}$ ostenjem in dvema ročajema, izdelan iz zelo finozrnate gline, nepopolno oksidacijsko žgan. Površina gladka, lisasta, svetlo rjave, rožnate, temno sive in sive barve. Na ramenih okrašena $\mathrm{z}$ dvema vodoravnima nizoma vtisnjenih jamic. Zemljanka I (1989); št. risbe: $\mathrm{H} 114 \mathrm{a}$.

2. Lonec - odl. ustja z ostenjem in odl. ročaja, izdelan iz finozrnate gline, nepopolno oksidacijsko žgan. Površina gladka, lisasta, zelo bledo rjave, sivo rjave, temno sive in zelo temno sive barve. Po celotni površini ramen okrašena s snopi plitvih navpičnih žlebov, na prehodu v vrat z vodoravnim žlebom. Zemljanka I (1989); št. risbe: H149.
3. Lonec - odl. ustja z ostenjem in odl. ročaja, izdelan iz finozrnate gline, nepopolno oksidacijsko žgan. Površina gladka, lisasta, svetlo rdeče, rdeče sive in rožnate barve. Po celotni površini ramen okrašena s snopi plitvih navpičnih žlebov, na prehodu v vrat $\mathrm{z}$ vodoravnim žlebom. Zemljanka I (1989); št. risbe: H159.

4. Lonec - odl. ostenja, izdelan iz finozrnate gline, nepopolno oksidacijsko žgan. Površina gladka, lisasta, svetlo rjave in sive barve. Na ramenih okrašena s snopi navpičnih žlebov. Zemljanka I (1989); št. risbe: H123.

\section{Tabla 6}

1. Lonec - odl. ustja z ostenjem in odlomka ostenja, izdelan iz finozrnate gline (LM34), nepopolno oksidacijsko žgan. Površina gladka, lisasta, zelo bledo rjave, svetlo rjavo sive in temno sive barve; delno izprana. Po celotni površini ramen okrašena s snopi plitvih rahlo poševnih žlebov, na prehodu v vrat $\mathrm{z}$ vodoravnim žlebom. Zemljanka I (1989); št. risbe: H153.

2. Lonec (rekonstruiran), izdelan iz drobnozrnate gline (LM53), nepopolno oksidacijsko žgan. Površina gladka, lisasta, zelo bledo rjave, sive in temno sive barve. Okras je izdelan v osnovni tehniki vrezovanja (žlebljenje). Zemljanka I (1989); št. risbe: H173.

3. Lonec - ohranjena več kot polovica posode, izdelan iz finozrnate gline, nepopolno oksidacijsko žgan. Površina gladka, lisasta, zelo bledo rjave in temno sive barve; delno izprana. Na ramenih okrašena s snopi navpičnih in rahlo poševnih žlebov, na vratu z vodoravnimi žlebovi. Zemljanka I (1989); št. risbe: H108.

\section{Tabla 7}

1. Lonec - odl. ustja $\mathrm{z}$ ostenjem in prehodom v ročaj, izdelan iz finozrnate gline, nepopolno oksidacijsko žgan. Površina gladka, lisasta, svetlo rjave, rjave in temno sive barve. Tik pod ustjem okrašena $z$ vodoravnim nizom vtisnjenih jamic, na vratu z vodoravnimi žlebovi. Zemljanka I (1989); št. risbe: H153b.

2. Lonec - odl. ostenja, izdelan iz zelo finozrnate gline, nepopolno oksidacijsko žgan. Površina gladka, lisasta, svetlo rjave in rdeče rumene barve; delno izprana. $\mathrm{Na}$ ramenu okrašena s snopom navpičnih žlebov. Zemljanka I (1989); št. risbe: H188.

3. Lonec - odl. ostenja, izdelan iz zelo finozrnate gline, nepopolno oksidacijsko žgan. Površina gladka, lisasta, svetlo rjave in temno sive barve. Po celotni površini ramen okrašena s trikotnimi vtisnjenimi jamicami. Zemljanka I (1989); št. risbe: H139.

4. Lonec - odl. ostenja s prehodom v ročaj, izdelan iz finozrnate gline, nepopolno oksidacijsko žgan. Površina gladka, lisasta, zelo bledo rjave in temno sive barve; delno izprana. Po celotni površini ramen okrašena z okroglimi vtisnjenimi jamicami. Zemljanka I (1989); št. risbe: H127.

5. Lonec - odl. ostenja, izdelan iz zelo finozrnate gline (LM07), nepopolno oksidacijsko žgan. Površina gladka, lisasta, svetlo rdeče rjave in sive barve; delno izprana. 
Okrašena z dvema rahlo poševnima nizoma trikotnih vtisnjenih jamic. Zemljanka I (1989); št. risbe: H180.

6. Lonec - odl. ustja $\mathrm{z}$ ostenjem in odl. dna $\mathrm{z}$ ostenjem, izdelan iz finozrnate gline, nepopolno oksidacijsko žgan. Površina gladka, lisasta, rjave in sive barve. Po celotni površini ramen okrašena s snopi navpičnih žlebov, na prehodu $\mathrm{v}$ vrat $\mathrm{z}$ dvema vodoravnima žlebovoma in $\mathrm{v}$ praznem vmesnem prostoru tik nad najširšim obodom s kratkim vodoravnim nizom ovalnih vtisnjenih jamic. Zemljanka I (1989); št. risbe: H187.

7. Lonec - odl. ustja z ostenjem, izdelan iz zelo finozrnate gline, nepopolno oksidacijsko žgan. Površina gladka, lisasta, bledo rjave in sivo rjave barve. Na ramenih okrašena z rahlo poševnimi skupinami vtisnjenih jamic, na prehodu v vrat Z vodoravnim žlebom. Zemljanka I (1989); št. risbe: H151.

8. Lonec-ohranjena nekoliko manj kot polovica posode, izdelan iz zelo finozrnate gline, nepopolno oksidacijsko žgan. Površina (mestoma poškodovana) je lisasta, zelo bledo rjava, rožnata, svetlo rdeča, svetlo rjavo siva, temno siva in siva, na notranji strani posode groba, na zunanji gladka. Zemljanka I (1989); št. risbe: H179.

\section{Tabla 8}

1. Lonec - odl. deloma ožganega ustja $z$ ostenjem, izdelan iz zelo finozrnate gline, nepopolno oksidacijsko žgan. Površina gladka, lisasta, svetlo rdeče rjave, svetlo rjave in svetlo sive barve. Zemljanka I (1989); št. risbe: H159.

2. Lonec - odl. ostenja z ročajem, izdelan iz zelo finozrnate gline, nepopolno oksidacijsko žgan. Površina gladka, lisasta, svetlo rjavo sive in zelo bledo rjave barve, na njej je rdeč premaz. Zemljanka I (1989); št. risbe: H137. (Sl. 8: 1).

3. Lonec - odl. ostenja, izdelan iz finozrnate gline, nepopolno oksidacijsko žgan. Površina gladka, lisasta, rdeče rumene, rdeče rjave, temno sive in zelo bledo rjave barve, na njej bledo rdeč premaz; delno izprana. Zemljanka I (1989); št. risbe: H164.

4. Lonec - odl. ostenja, izdelan iz zelo finozrnate gline, nepopolno oksidacijsko žgan. Površina gladka, lisasta, bledo rjave, sivo rjave, temno sive in sive barve; delno izprana. Zemljanka I (1989); št. risbe: H168b.

5. Lonec - odl. ustja z ostenjem, morda del iste posode kot odl. št. risbe $168 \mathrm{~b}$. Izdelan iz zelo finozrnate gline, nepopolno oksidacijsko žgan. Površina gladka, lisasta, bledo rjave, sivo rjave, temno sive in sive barve; delno izprana. Zemljanka I (1989); št. risbe: H168a.

\section{Tabla 9}

1. Lonec - odlomki ostenja, izdelan iz drobnozrnate gline, nepopolno oksidacijsko žgan. Površina je lisasta svetlo rjava, rjava in siva, na notranji strani groba, na zunanji gladka; delno izprana. Na ramenih okrašena s snopi navpičnih in rahlo poševnih žlebov, $\mathrm{v}$ enem od praznih vmesnih prostorčkov na prehodi $\mathrm{v}$ vrat $\mathrm{z}$ vtisnjenima jamicama. Zemljanka I (1989); št. risbe: H174.

2. Lonec - odl. ostenja, izdelan iz finozrnate gline, nepopolno oksidacijsko žgan. Površina gladka in lisasta, zelo bledo rjave in sive barve. $\mathrm{V}$ spodnjem delu ramen okrašena z vtisnjeno jamico. Zemljanka I (1989); št. risbe: H162.

3. Lonec - odl. ustja z ostenjem in ročajem, izdelan iz zelo finozrnate gline, nepopolno oksidacijsko žgan. Površina gladka, lisasta, zelo bledo rjave, sivo rjave in sive barve; delno izprana. Na vratu okrašena $\mathrm{z}$ vodoravnimi žlebovi. Zemljanka I (1989); št. risbe: H136.

4. Lonec - odl. ustja z ostenjem, izdelan iz zelo finozrnate gline, nepopolno oksidacijsko žgan. Površina gladka, lisasta, svetlo rdeče rjave, rožnate, temno sive in sive barve. Zemljanka I (1989); št. risbe: H181.

5. Odl. dna $\mathrm{z}$ ostenjem posode, izdelane iz zelo finozrnate gline, nepopolno oksidacijsko žgane. Površina gladka, lisasta, svetlo rjave, rožnate, temno sive in sive barve. Zemljanka I (1989); št. risbe: H114b.

6. Odl. dna $z$ ostenjem posode, izdelane iz zelo finozrnate gline, nepopolno oksidacijsko žgane. Površina gladka, zelo bledo rjave barve, na njej rdeč premaz; delno izprana. Zemljanka I (1989); št. risbe: H182.

7. Odl. dna $z$ ostenjem posode, izdelane iz zelo finozrnate gline, nepopolno oksidacijsko žgane. Površina gladka, lisasta, zelo bledo rjave in svetlo rjavo sive barve; delno izprana. Zemljanka I (1989); št. risbe: H169.

8. Zajemalka - odl. recipienta $\mathrm{z}$ votlim nastavkom za držaj, izdelana iz finozrnate gline, nepopolno oksidacijsko žgana. Površina gladka, lisasta, svetlo sive in rožnate barve; delno izprana in ožgana. Zemljanka I (1989); št. risbe: H222.

9. Zajemalka - odl. recipienta $\mathrm{z}$ votlim nastavkom za držaj, izdelana iz finozrnate gline, nepopolno oksidacijsko žgana. Površina gladka, lisasta, rožnato sive in svetlo sive barve. Zemljanka I (1989); št. risbe: H221.

10. Zajemalka - odl. recipienta $\mathrm{z}$ votlim nastavkom za držaj, izdelana iz zelo finozrnate gline, nepopolno oksidacijsko žgana. Površina gladka, lisasta, rožnate in sive barve; delno izprana. Zemljanka I (1989); št. risbe: H116.

11. Izvrtek sekire iz serpentinita. Zemljanka I (1989); št. risbe: H2019_8.

12. Odl. dleta iz lahkega belega kamna. Zemljanka I (1989); št. risbe: H2019_8.

\section{Tabla 10}

1. Skleda (na nogi?) - odl. ustja z ostenjem in prehodom $\mathrm{v}$ visečo jezičasto apliko na najširšem obodu, izdelana iz zelo finozrnate gline, nepopolno oksidacijsko žgana. Površina gladka, zelo bledo rjave barve, na njej je premaz rdeče rjave in zelo temno sive barve. Ostenje sklede po žganju perforirano. Zemljanka II (1989); št. risbe: H53.

2. Odl. noge posode (sklede?), izdelane iz zelo finozrnate gline, nepopolno oksidacijsko žgane, v končni fazi redukcijsko. Površina je temno sive barve, na notranji strani posode gladka in mat, na zunanji svetlikajoča se (spolirana). Zemljanka II (1989); št. risbe: H42.

3. Skleda na nizki nogi - ohranjena nekoliko manj kot polovica posode, izdelana iz zelo finozrnate gline, nepopolno oksidacijsko žgana, v končni fazi redukcijsko. Površina gladka, lisasta, sive in svetlo rdeče barve (poškodovana). Zemljanka II (1989); št. risbe: H35.

4. Skleda na nogi - večji odl. ustja z ostenjem in prehodom v nogo, izdelana iz zelo finozrnate gline, nepopolno 
oksidacijsko žgana, v končni fazi redukcijsko. Površina gladka in sive barve. Zemljanka II (1989); št. risbe: H32.

5. Skleda na nogi - odl. ustja z ostenjem, odl. roba noga in odl. dna $\mathrm{z}$ ostenjem in $\mathrm{z}$ zgornjim delom noge, izdelana iz zelo finozrnate gline, nepopolno oksidacijsko žgana, v končni fazi redukcijsko. Površina gladka, lisasta, temno sive in sive barve, na njej premaz zelo temno sive barve; delno izprana. Zemljanka II (1989); št. risbe: H25.

\section{Tabla 11}

1. Skleda na nogi - odl. dna $\mathrm{z}$ ostenjem sklede in $\mathrm{z}$ zgornjim delom noge, izdelana iz zelo finozrnate gline, nepopolno oksidacijsko žgana, v končni fazi redukcijsko. Površina gladka in sive barve. Zemljanka II (1989); št. risbe: $\mathrm{H} 33$.

2. Odl. roba noge posode (sklede?), izdelane iz zelo finozrnate gline, nepopolno oksidacijsko žgane, v končni fazi redukcijsko. Površina gladka, temno sive barve. Zemljanka II (1989); št. risbe: H51.

3. Rob keramičnega predmeta - morda del noge posode. Izdelan iz zelo finozrnate gline, nepopolno oksidacijsko žgan, redukcijsko v končni fazi. Površina gladka in sive barve; delno izprana. Zemljanka II (1989); št. risbe: H52.

4. Dno posode (sklede?) z zgornjim delom noge, izdelane iz zelo finozrnate gline, nepopolno oksidacijsko žgane, v končni fazi redukcijsko. Površina temno sive barve, na notranji strani noge groba, na zunanji gladka. Zemljanka II (1989); št. risbe: H06.

5. Skleda (na nogi?) - odl. ustja $z$ ostenjem in visečo jezičasto nalepko, izdelana iz zelo finozrnate gline, nepopolno oksidacijsko žgana, v končni fazi redukcijsko. Površina gladka in sive barve; delno izprana (lise zelo bledo rjave barve). Zemljanka II (1989); št. risbe: H36.

6. Skodela - odl. ustja z ostenjem, izdelana iz zelo finozrnate gline, nepopolno oksidacijsko žgane, v končni fazi redukcijsko. Površina gladka in sive barve; delno izprana (lise bledo rjave in svetlo sive barve). Med ustjem in najširšim obodom okrašena $\mathrm{z}$ okroglo apliko. Zemljanka II (1989); št. risbe: H21.

7. Skleda - odl. ustja z ostenjem, izdelana iz finozrnate gline, nepopolno oksidacijsko žgana. Površina gladka, lisasta, rdeče rumene in sive barve. Zemljanka II (1989); št. risbe: $\mathrm{H} 17$.

8. Skleda (rekonstruirana), izdelana iz zelo finozrnate gline, nepopolno oksidacijsko žgana. Površina gladka, lisasta, bledo rjave, temno sive in sive barve. Na notranji strani posode ohranjeni zogleneli organski ostanki. Zemljanka II (1989); št. risbe: H104.

9. Skleda $\mathrm{z}$ držajem (rekonstruirana), izdelana iz finozrnate gline, nepopolno oksidacijsko žgana. Površina gladka, lisasta, rdeče rjave, temno sive in sive barve; delno izprana. Zemljanka II (1989); št. risbe: H20.

10. Skleda (rekonstruirana), izdelana iz finozrnate gline, nepopolno oksidacijsko žgana. Površina gladka, lisasta, rdeče rjave, temno sive in sive barve. Zemljanka II (1989); št. risbe: H34.

11. Skodela - odl. ustja z ostenjem in ročajem, izdelana iz finozrnate gline, nepopolno oksidacijsko žgana. Površina gladka, lisasta, zelo bledo rjave, rožnate in sive barve. Tik pod ustjem in na ročaju okrašena $\mathrm{z}$ okroglimi vtisnjenimi jamicami, med najširšim obodom in ustjem s snopom rahlo poševnih žlebov. Zemljanka II (1989); št. risbe: H18.

\section{Tabla 12}

1. Skleda - odl. ustja z ostenjem, izdelana iz zelo finozrnate gline, nepopolno oksidacijsko žgana. Površina gladka, zelo bledo rjave barve, na njej rdeč premaz. Zemljanka II (1989); št. risbe: H27. (Sl. 8: 3).

2. Skleda - odl. ustja z ostenjem, izdelana iz zelo finozrnate gline, nepopolno oksidacijsko žgana. Površina gladka, lisasta, rdeče rumene, svetlo rdeče in svetlo sive barve; delno ožgana. Zemljanka II (1989); št. risbe: H74.

3. Skleda - odl. ustja $\mathrm{z}$ ostenjem in prehodom v izliv, izdelana iz zelo finozrnate gline, nepopolno oksidacijsko žgana, v končni fazi redukcijsko. Površina gladka in sive barve. Zemljanka II (1989); št. risbe: H49.

4. Skleda - skoraj v celoti ohranjena, z izlivom, izdelana iz finozrnate gline, nepopolno oksidacijsko žgana. Površina gladka, lisasta, svetlo sive, rožnate in svetlo rjave barve. Na notranji strani dna ožgana. Zemljanka II (1989); št. risbe: $\mathrm{H} 225$.

5. Skleda - odl. ustja z ostenjem, izdelana iz zelo finozrnate gline, nepopolno oksidacijsko žgana. Površina gladka, lisasta, rožnate in zelo bledo rjave barve; delno izprana. Zemljanka II (1989); št. risbe: H37.

6. Skodela - odl. ustja $\mathrm{z}$ ostenjem, izdelana iz zelo finozrnate gline, nepopolno oksidacijsko žgana. Površina gladka, lisasta, rožnate, temno sive in sive barve; delno izprana. Zemljanka II (1989); št. risbe: H38.

7. Skleda - odl. ustja $z$ ostenjem, izdelana iz zelo finozrnate gline, nepopolno oksidacijsko žgana. Površina gladka, lisasta, bledo rjave in zelo bledo rjave barve; delno izprana. Zemljanka II (1989); št. risbe: H19a.

8. Miniaturna skodela (rekonstruirana), izdelana iz zelo finozrnate gline, nepopolno oksidacijsko žgana. Površina gladka, lisasta, svetlo sive in zelo bledo rjave barve; delno izprana. Zemljanka II (1989); št. risbe: H89.

9. Miniaturna skodela - skoraj v celoti ohranjena, z dvema okroglima aplikama tik pod ustjem, izdelana iz zelo finozrnate gline, nepopolno oksidacijsko žgana. Groba površina je lisasta, zelo bledo rjave, rožnate, sive in temno sive barve; delno izprana. Zemljanka II (1989); št. risbe: H106a.

10. Skleda - odl. ustja z ostenjem in odlomka ostenja, izdelana iz zelo finozrnate gline, nepopolno oksidacijsko žgana. Površina gladka, lisasta, bledo rjave, temno sive in sive barve; delno izprana. Zemljanka II (1989); št. risbe: H75.

\section{Tabla 13}

1. Vrč - odl. ostenja, izdelan iz zelo finozrnate gline, nepopolno oksidacijsko žgan, v končni fazi redukcijsko. Površina gladka, lisasta, zelo bledo rjave, temno sive in sive barve; delno izprana. Na ramenih okrašena s snopi plitvih navpičnih žlebov. Zemljanka II (1989); št. risbe: H107.

2. Vrč - odl. ostenja, izdelan iz zelo finozrnate gline, nepopolno oksidacijsko žgan, v končni fazi redukcijsko. 
Površina gladka in sive barve. Na ramenih okrašena $\mathrm{s}$ snopi navpičnih žlebov. Zemljanka II (1989); št. risbe: H80.

3. Vrč - odl. ostenja in odl. dna z ostenjem, izdelan iz zelo finozrnate gline, nepopolno oksidacijsko žgan, v končni fazi redukcijsko. Površina temno sive barve, na notranji strani gladka, na zunanji svetlikajoča se (spolirana). Na ramenih okrašena s snopi poševnih žlebov $v$ cik-caku, na vratu z vodoravnimi žlebovi. Zemljanka II (1989); št. risbe: H16.

4. Vrč - odl. ročaja, izdelan iz zelo finozrnate gline, nepopolno oksidacijsko žgan. Površina gladka, lisasta, zelo bledo rjave in sive barve, na njej rdeče rjav premaz. Zemljanka II (1989); št. risbe: H28.

5. Odl. ostenja posode, izdelane iz zelo finozrnate gline, nepopolno oksidacijsko žgane. Površina gladka, lisasta, zelo bledo rjave in sive barve, na njej rdeče rjav premaz; delno izprana. Okrašena $\mathrm{z}$ apliko, ki jo sestavljajo štiri bunčice. Zemljanka II (1989); št. risbe: H14.

6. Vrč - odl. ostenja s prehodom v ročaj in odl. dna $\mathrm{z}$ ostenjem, izdelan iz zelo finozrnate gline, nepopolno oksidacijsko žgan, v končni fazi redukcijsko. Površina je lisasta zelo bledo rjava in zelo temno siva, na notranji strani gladka, na zunanji svetlikajoča se (spolirana). Na ramenih okrašena s snopi navpičnih žlebov, na prehodu $\mathrm{v}$ vrat $\mathrm{z}$ drobnimi vtisnjenimi jamicami. Zemljanka II (1989); št. risbe: H24.

7. Lonec - odl. ustja $\mathrm{z}$ ostenjem, 2 odlomka ostenja $\mathrm{z}$ ročajem in odl. ostenja, izdelan iz zelo finozrnate gline, nepopolno oksidacijsko žgan. Površina gladka, lisasta, rjave, zelo bledo rjave in sive barve. Na ramenih okrašena s poševnimi snopi vtisnjenih jamic. Zemljanka II (1989); št. risbe: $\mathrm{H} 50$.

8. Odl. okrašenega ostenja posode, izdelane iz zelo finozrnate gline, nepopolno oksidacijsko žgane. Površina gladka, temno sive barve. Okrašena $z$ vodoravnimi žlebovi. Zemljanka II (1989); št. risbe: H40.

9. Lonec - odl. ostenja, izdelan iz finozrnate gline (LM31), nepopolno oksidacijsko žgan. Površina je lisasta, svetlo rjava in siva, na notranji strani groba, na zunanji gladka. Na ramenu okrašena s snopom plitvih navpičnih žlebov. Zemljanka II (1989); št. risbe: H65.

10. Lonec - odlomka ostenja in večji odl. dna z ostenjem, izdelan iz zelo finozrnate gline, nepopolno oksidacijsko žgan. Površina gladka, lisasta, svetlo rjave, temno sive in sive barve; delno izprana. Na ramenu okrašena s snopom rahlo poševnih žlebov. Zemljanka II (1989); št. risbe: H23.

11. Lonec - odl. ostenja, izdelan iz zelo finozrnate gline, nepopolno oksidacijsko žgan. Površina gladka, lisasta, sivo rjave, temno sive in sive barve. Okras je izdelan v osnovni tehniki vrezovanja (žlebljenje). Zemljanka II (1989); št. risbe: $\mathrm{H} 31$.

12. Lonec - odl. ostenja, izdelan iz zelo finozrnate gline, nepopolno oksidacijsko žgan, v končni fazi redukcijsko. Površina gladka, lisasta, temno sive in sive barve; delno izprana. Na ramenu okrašena s snopi rahlo poševnih žlebov. Zemljanka II (1989); št. risbe: H29.

13. Lonec - odl. ostenja, izdelan iz zelo finozrnate gline, nepopolno oksidacijsko žgan. Površina gladka, lisasta, svetlo rjave, zelo bledo rjave in sive barve; delno izprana. $\mathrm{Na}$ ramenu okrašena s snopom plitvih rahlo poševnih žlebov. Zemljanka II (1989); št. risbe: H81.
14. Lonec - odl. ostenja, izdelan iz zelo finozrnate gline, nepopolno oksidacijsko žgan. Površina gladka, lisasta, svetlo rjave in sive barve. Na ramenu okrašena s snopom rahlo poševnih žlebov. Zemljanka II (1989); št. risbe: H15.

15. Lonec - odl. ostenja, izdelan iz zelo finozrnate gline, nepopolno oksidacijsko žgan. Površina gladka, lisasta, svetlo rjave in sive barve. Na ramenu okrašena s snopom plitvih navpičnih žlebov. Zemljanka II (1989); št. risbe: H71.

\section{Tabla 14}

1. Lonec - odl. ustja $\mathrm{z}$ ostenjem in ročajem, izdelan iz zelo finozrnate gline, nepopolno oksidacijsko žgan. Površina gladka, lisasta, bledo rjave, temno sive in sive barve. Na ramenu okrašena $\mathrm{z}$ rahlo poševnimi vrezi, na prehodu v vrat z vtisnjenimi jamicami. Zemljanka II (1989); št. risbe: H125.

2. Lonec - odl. ustja $z$ ostenjem in ročajem, izdelan iz zelo finozrnate gline (, nepopolno oksidacijsko žgan. Površina gladka, lisasta, svetlo rjave in svetlo sive barve; delno izprana in ožgana. Na ramenu okrašena $z$ rahlo poševnimi vrezi, na prehodu $\mathrm{v}$ vrat in pod ročajem $\mathrm{z}$ vtisnjenimi jamicami. Zemljanka II (1989); št. risbe: H47.

3. Lonec - rekonstrukcija iz več odlomkov, izdelan iz zelo finozrnate gline, nepopolno oksidacijsko žgan. Površina gladka, lisasta, rožnate in zelo bledo rjave barve; delno izprana. Zemljanka II (1989); št. risbe: H55.

\section{Tabla 15}

1. Lonec - odlomka ustja $\mathrm{z}$ ostenjem, odl. ostenja $\mathrm{z}$ ročajem in odl. ostenja, izdelan iz finozrnate gline, nepopolno oksidacijsko žgan. Površina gladka, lisasta, zelo bledo rjave, svetlo sive, temno sive in sive barve; delno izprana. Zemljanka II (1989); št. risbe: H10.

2. Lonec - odl. ustja $z$ ostenjem in odl. ostenja $\mathrm{z}$ delom ročaja, zdelan je iz finozrnate gline, nepopolno oksidacijsko žgan. Površina gladka, lisasta, zelo bledo rjave, svetlo rjave in sive barve. Po celotni površini ramen okrašena $s$ snopi navpičnih vrezov, na prehodu $\mathrm{v}$ vrat $\mathrm{z}$ vodoravnima vrezoma. Zemljanka II (1989); št. risbe: H83.

3. Lonec - večji odl. ustja $z$ ostenjem in ročajem, izdelan iz finozrnate gline, nepopolno oksidacijsko žgan. Površina gladka, zelo bledo rjave barve, na njej lise sive barve; delno izprana. Zemljanka II (1989); št. risbe: H05.

\section{Tabla 16}

1. Lonec - odl. ostenja z delom ročaja, izdelan iz zelo finozrnate gline, nepopolno oksidacijsko žgan. Površina gladka, lisasta, rdeče rumene, zelo bledo rjave in sive barve; delno izprana. Na ramenih okrašena s snopi navpičnih žlebov. Zemljanka II (1989); št. risbe: H43.

2. Lonec-odl. ostenja $z$ ročajem, izdelan iz zelo finozrnate gline, nepopolno oksidacijsko žgan. Površina gladka, zelo bledo rjave barve; na njej rdeče rjav premaz. Na prehodu $\mathrm{v}$ vrat okrašena $\mathrm{z}$ vodoravnim vrezom. Površina je delno izprana. Zemljanka II (1989); št. risbe: H54. 
3. Odl. ustja z ostenjem posode, izdelane iz zelo finozrnate gline, nepopolno oksidacijsko žgane. Površina gladka, lisasta, svetlo rjave in sive barve. Zemljanka II (1989); št. risbe: H56.

4. Lonec - odl. ustja $\mathrm{z}$ ostenjem, izdelan iz zelo finozrnate gline, nepopolno oksidacijsko žgan. Površina gladka, lisasta, svetlo rdeče in rdeče sive barve. Zemljanka II (1989); št. risbe: $\mathrm{H} 45$.

5. Lonec - odl. ustja $\mathrm{z}$ ostenjem, izdelan iz finozrnate gline, nepopolno oksidacijsko žgan. Površina gladka, lisasta, svetlo rjave in sive barve. Na prehodu v vrat okrašena $\mathrm{Z}$ vodoravnim žlebom, pod njim $\mathrm{z}$ vodoravnim nizom vtisnjenih jamic. Zemljanka II (1989); št. risbe: H22.

6. Odl. dna $z$ ostenjem posode, izdelane iz zelo finozrnate gline, nepopolno oksidacijsko žgane. Površina gladka, lisasta, bledo rjave, zelo bledo rjave in sive barve, na njej rdeč premaz; delno izprana. Zemljanka II (1989); št. risbe: $\mathrm{H} 19 \mathrm{~b}$.

7. Odl. dna $z$ ostenjem posode, izdelane iz zelo finozrnate gline, nepopolno oksidacijsko žgane, v končni fazi redukcijsko. Površina gladka in sive barve; delno izprana. Zemljanka II (1989); št. risbe: H41.

8. Zajemalka - odl. recipienta $\mathrm{z}$ nastavkom za držaj, izdelana iz zelo finozrnate gline, nepopolno oksidacijsko žgana. Površina gladka, lisasta, rdeče rumene in svetlo sive barve; delno izprana. Zemljanka II (1989); št. risbe: H26.

9. Valjasti pečatnik - v celoti ohranjen, izdelan iz zelo finozrnate gline, nepopolno oksidacijsko žgan. Površina gladka, lisasta, temno sive in sivo rjave barve. Delovna površina pečatnika narejena $\mathrm{z}$ vzporednimi vodoravnimi vrezi, ob spodnjem robu vzporedni kratki ravni vrezi, ob zgornjem robu izmenjujoče se skupine kratkih poševnih vrezov. Zemljanka II (1989); št. risbe: H1. (Sl. 10: 5).

10. Keramična ploščica $\mathrm{z}$ luknjo - v celoti ohranjena, izdelana iz odlomka ustja $\mathrm{z}$ ostenjem posode, narejene iz zelo fino zrnata gline, nepolno oksidacijsko žgane. Površina gladka, svetlo rjave barve, na njej premaz rdeče barve. $\mathrm{Na}$ ploščici so štiri vzporedni vrezi in en kratek vrez, ki je prečen na njih. Okras je bil narejen pred žganjem posode. Premaz je viden tudi na stranskih robovih keramične ploščice. Zemljanka II (1989); št. risbe: H85.

11. Izvrtek sekire iz serpentinita. Zemljanka II (1989); št. risbe: H2019_1.

12. Izvrtek sekire iz serpentinita. Zemljanka II (1989); št. risbe: H2019_2.

13. Izvrtek sekire iz serpentinita. Zemljanka II (1989); št. risbe: H2019_12.

14. V celoti ohranjena dletasta sekira. Rezilo ostro, čelo, stranska robova in obe ploskvi izbrušeni, vendar ne na sijaj (vidni sledovi brušenja). Zemljanka II (1989); št. risbe: H2019_3.

\section{Tabla 17}

1. Kamnita sekira iz zelenega kamna. Rezilo ostro, stranska roba in obe ploskvi izglajeni. Čelo sekire in deloma stranska robova odlomljeni. Zemljanka II (1989); št. risbe: H2019_4.

2. Fragmentirane žrmlje. Delovna površina konkavno izbrušena, spodnja ploskev in en rob polkrožno oklesana.
Ostala robova odlomljena po uporabi. Zemljanka II (1989); št. risbe: H2019_5.

3. Kamen z delno navrtano luknjo. Brez sledov brušenja ali tolčenja. Zemljanka II ali zemljanka III (1989); št. risbe: H2019_13.

4. Izvrtek sekire iz serpentinita, pripadajoč sekiri št. risbe H2019_11. Zemljanka II ali zemljanka III (1989); št. risbe: H2019_9.

5. Kopača z luknjo, izdelana iz serpentinita, v celoti ohranjena. Rezilo ostro, stranska roba in obe ploskvi izglajeni. Iz luknje sekire izhaja izvrtek št. risbe H2009_9. Zemljanka II ali zemljanka III (1989); št. risbe: H2019_11.

6. Izvrtek sekire iz serpentinita. Ob vzhodnem profilu, kv. 16, gl. 55 cm (Zemljanka III (1989)?); št. risbe: H2019_13.

7. Dletasta kamnita sekira iz temno sivega kamna. Rezilo ostro, ploskvi, robova in čelo okrušeni. Zemljanka III (1989)?; št. risbe: H2019_14.

8. Fragmentiran tolkač iz svetlo sivo do temno sivo zelenega kamna. Sledovi uporabe na obeh krajših robovih. Zemljanka III (1989); št. risbe: H2019_6.

9. Odl. dna z zgornjim delom noge posode (sklede?), izdelane iz zelo finozrnate gline, nepopolno oksidacijsko žgane. Površina gladka, lisasta, bledo rjave in temno sive barve; delno izprana. Zemljanka III (1989); št. risbe: H198.

10. Odl. ustja $z$ ostenjem sklede ali skodele, izdelane iz zelo finozrnate gline, nepopolno oksidacijsko žgane. Površina gladka, lisasta, svetlo rjave in temno sive barve; delno izprana. Med ustjem in najširšim obodom okrašena z dvema vodoravnima nizoma okroglih vtisnjenih jamic. $\mathrm{Na}$ notranji površini zogleneli organski ostanki. Zemljanka III (1989); št. risbe: H198b.

11. Odl. izliva posode, izdelane iz zelo finozrnate gline, nepopolno oksidacijsko žgane. Površina gladka, rdeče rumene barve. Zemljanka III (1989); št. risbe: H191.

\section{Tabla 18}

1. Pekač - odl. roba z dnom, izdelan iz zelo finozrnate gline, nepopolno oksidacijsko žgan. Površina gladka, lisasta, sivo rjave, zelo bledo rjave in sive barve. Na notranji strani odlomka posode ohranjeni zogleneli organski ostanki. Zemljanka III (1989); št. risbe: H208.

2. Skleda - odl. ustja z ostenjem in držajem, izdelana iz zelo finozrnate gline, nepopolno oksidacijsko žgana, v končni fazi redukcijsko. Površina gladka, siva, mestoma svetlikajoča se (spolirana), delno izprana. Med ustjem in najširšim obodom okrašena $\mathrm{z}$ apliko v obliki petkrake zvezde, obrobljeno s koncentričnimi vrezanimi krožci in s snopi navpičnih vrezov. Zemljanka III (1989); št. risbe: H203.

3. Skodela - odl. ustja z ostenjem in držajem, izdelana iz zelo finozrnate gline, nepopolno oksidacijsko žgana. Površina gladka, lisasta, zelo bledo rjave, svetlo rjavo sive, rožnate, temno sive in sive barve; delno izprana. Zemljanka III (1989); št. risbe: H196.

4. Skodela - ohranjena nekoliko manj kot polovica posode s prehodom v dodatni element (apliko, držaj ali izliv), izdelana iz zelo finozrnate gline, nepopolno oksidacijsko žgana. Površina gladka, lisasta, zelo bledo rjave, svetlo rjavo sive in rožnate barve; delno izprana. Zemljanka III (1989); št. risbe: H195. 
5. Lonec - odl. ustja z ostenjem, izdelan iz finozrnate gline, nepopolno oksidacijsko žgan. Površina lisasta, svetlo rjava, rjava in siva, na notranji strani groba, na zunanji gladka. Zemljanka III (1989); št. risbe: H192.

6. Lonec - odl. dna $\mathrm{z}$ ostenjem in prehodoma $\mathrm{v}$ dva ročaja, izdelan iz zelo finozrnate gline, nepopolno oksidacijsko žgan. Površina je lisasta rdeče rumena in temno siva, na notranji strani groba, na zunanji gladka. Zemljanka III (1989); št. risbe: H197.

\section{Tabla 19}

1. Lonec - odl. ustja z ostenjem, izdelan iz zelo finozrnate gline, nepopolno oksidacijsko žgan, v končni fazi redukcijsko. Površina gladka, lisasta, sivo rjave, zelo bledo rjave in sive barve. Na ramenih okrašena $\mathrm{z}$ okroglima aplikama. Zemljanka III (1989); št. risbe: H207.

2. Lonec - odl. ustja $\mathrm{z}$ ostenjem, izdelan iz zelo finozrnate gline, nepopolno oksidacijsko žgan. Površina je lisasta, zelo bledo rjave in rdeče rumene barve. Zemljanka III (1989); št. risbe: H205.

3. Lonec (ohranjena več kot polovica posode), izdelan iz zelo finozrnate gline, nepopolno oksidacijsko žgan. Površina je groba in lisasta, zelo bledo rjave, sivo rjave in temno sive barve; delno izprana. Zemljanka III (1989); št. risbe: $\mathrm{H} 204$.

4. Miniaturna steklenička (skoraj v celoti ohranjena), izdelana iz zelo finozrnate gline, nepopolno oksidacijsko žgana, v končni fazi redukcijsko. Površina je sive barve, na notranji strani groba, na zunanji gladka. Tik pod ustjem okrašena s podolgovatimi vtisnjenimi jamicami. Zemljanka III (1989); št. risbe: H202.

5. Lonec (ohranjena več kot polovica posode), izdelan iz zelo finozrnate gline, nepopolno oksidacijsko žgan. Površina lisasta, svetlo rjavo sive, zelo bledo rjave, temno sive in sive barve, na notranji strani groba, na zunanji gladka. Zemljanka III (1989); št. risbe: H194.

6. Zajemalka - odl. recipienta $\mathrm{z}$ votlim nastavkom $\mathrm{za}$ držaj, izdelana iz zelo finozrnate gline, nepopolno oksidacijsko žgana, v končni fazi redukcijsko. Površina gladka in sive barve; delno poškodovana. Zemljanka III (1989); št. risbe: $\mathrm{H} 199$.

Tabla 20

1. Skleda - odl. ustja $\mathrm{z}$ ostenjem in visečo jezičasto apliko na najširšem obodu, izdelana iz zelo finozrnate gline, nepopolno oksidacijsko žgana, v končni fazi redukcijsko. Površina gladka in sive barve. Jama II (1988)?; št. risbe: $\mathrm{H} 131$.

2. Odl. ustja $z$ ostenjem sklede ali skodele, izdelana iz zelo finozrnate gline, nepopolno oksidacijsko žgana. Površina gladka, lisasta, sivo rjave in sive barve. Jama II (1988); št. risbe: H215.

3. Skleda - odl. ustja z ostenjem, izdelana iz drobnozrnate gline, nepopolno oksidacijsko žgana. Površina gladka, lisasta, svetlo sivo rjave in temno sive barve. Večina površine je izprane. Jama II (1988); št. risbe: H212b.
4. Vrč - odl. okrašenega ostenja, izdelan iz zelo finozrnate gline, nepopolno oksidacijsko žgan, redukcijsko v končni fazi. Površina gladka, temno sive barve. Večina originalne površine izprane. Na ramenih okrašena s snopom navpičnih žlebov. Jama II (1988); št. risbe: H213.

5. Lonec - odl. ustja z ostenjem, izdelan iz zelo finozrnate gline, nepopolno oksidacijsko žgan. Površina je lisasta svetlo rdeče rjava in rdeče rumena, na notranji strani posode groba, na zunanji gladka; delno izprana. Jama II (1988); št. risbe: H212.

6. Lonec - 2 večja kosa ustja $\mathrm{z}$ ostenjem in najširšim obodom posode ter ročajem, izdelan iz drobnozrnate gline, nepopolno oksidacijsko žgan. Površina je lisasta svetlo rjava, bledo rjava in temno siva, na notranji strani posode groba, na zunanji gladka; delno izprana. Jama II (1988); št. risbe: $\mathrm{H} 210$

7. Vrč - odl. ostenja, izdelan iz zelo finozrnate gline, nepopolno oksidacijsko žgan $\mathrm{z}$ redukcijsko atmosfero $\mathrm{v}$ končni fazi. Površina gladka, temno sive barve. Na ramenih okrašena s plitvimi žlebovi. Jama II (1988); št. risbe: H217.

8. Lonec - odl. ustja z ostenjem, izdelan iz zelo finozrnate gline, nepopolno oksidacijsko žgan. Površina je lisasta bledo rjava, svetlo rjava in temno siva, na notranji strani posode groba, na zunanji gladka. Jama II (1988); št. risbe: H209.

9. Odl. dna $z$ ostenjem posode, izdelane iz finozrnate gline, nepopolno oksidacijsko žgane. Površina je lisasta sivo rjava, bledo rjava in siva, na notranji strani posode groba, na zunanji gladka. Jama II (1988); št. risbe: H214.

10. Kamniti tolkač iz serpentinita. Sledovi tolčenja na krajšem spodnjem robu. Jama I (1988); št. risbe: H2019_15.

Tabla 21

1. Posoda - odl. ostenja $\mathrm{z}$ najširšim obodom in odl. ostenja z najširšim obodom in držajem v obliki človeškega stopala, izdelana iz zelo finozrnate gline, nepopolno oksidacijsko žgana. Površina gladka, lisasta, rjave in temno sive barve. Jama za stojko 7 (1988); št. risbe: H224.

2. Skleda - odl. ustja $\mathrm{z}$ ostenjem in dvema visečima jezičastima aplikama na najširšem obodu, izdelana iz zelo finozrnate gline, nepopolno oksidacijsko žgana. Površina gladka, lisasta, sveto rdeče in svetlo rdeče rjave barve. Kontekst neznan; št. risbe: $\mathrm{H} 223$.

3. Skodela (rekonstruirana), izdelana iz zelo finozrnate gline, nepopolno oksidacijsko žgana. Površina gladka, lisasta, rožnate, svetlo rjavo sive in sive barve; delno izprana. Kontekst neznan; št. risbe: $\mathrm{H} 230$.

4. Izvrtek sekire iz serpentinita. Kv. 3, nad prazgodovinsko plastjo (1989); št. risbe: H230.

5. Brusni kamen. Kontekst neznan (1988); št. risbe: H2019_16.

6. Brusni kamen. Kontekst neznan (1988); št. risbe: H2019_17. 
ARTNER et al. 2012 = W. Artner, M. Brandl, G. Christandl, C. Gutjarh, J. Obereder, W. Postl, M. Trausner 2012, Die kupferzeitliche Höhensiedlung auf der 'Kanzel' bei Graz, Steiermark. - Fundberichte aus Österreich 50 (2011), 43-66.

BÁNFFY, E. 1994, Transdanubia and Eastern Hungary in the Early Copper Age. - A Nyíregyházi Jósa András Múzeum évkönyve 36, 291-295.

BÁNFFY, E. 1995a, Neolithic and Copper Age settlements at Hahót and Zalaszentbalázs (Zalaszentbalazs-Pusztatető, Hahot-Szartori I-II). - V: B. M. Szőke (ur.), Archaeology and settlement history in the Hahot basin, South-West Hungary, Antaeus 22, 35-50.

BÁNFFY, E. 1995b, South West Transdanubia as a mediating area. On the cultural history of the Early and Middle Chalcolithic. - V: B. M. Szőke (ur.), Archaeology and settlement history in the Hahót basin, South-West Hungary, Antaeus 22, 157-196.

BARNA, J. P. 2003, Középső rézkori és késő bronzkori településrészletek Tornyiszentmiklósról. - Régészeti kutatások Magyarországon 2001 / Archaeological investigations in Hungary 2001, 47-62, Budimpešta.

BAŠ, F. 1937, Izgoni na Dravskem polju. - Časopis za zgodovino in narodopisje 32, 325-340.

BOLTA, L. 1962-1963, Neolitska naselbina na Rifniku. Arheološki vestnik 13-14, 287-291.

BUDJA, M. 1992, Pečatniki v slovenskih neolitskih naselbinskih kontekstih. - Poročilo o raziskovanju paleolita, neolita in eneolita $v$ Sloveniji 20, 95-109.

BUDJA, M. 1995, Neolithic and Eneolithic settlement patterns in the Bela krajina Region of Slovenia. - V: A. Aspes (ur.), Symposium Settlement patterns between the Alps and the Black Sea 5th to 2nd millenium B.C. Atti del Siposio Internazionale Modelli Insediativi tra Alpi e Mar Nero dal $5^{\circ}$ al $2^{\circ}$ Millenio A.C., Verona - Lazise 1992, Memore del museo civico di storia naturale di Verona, IIa serie, sezione scienze dell 'uomo 4, 119-127, Verona.

CIGLENEČKI, S., M. STRMČNIK GULIČ 2002, Sledovi zgodnje slovanske poselitve južno od Maribora (Spuren frühslawischer Besiedlung südlich von Maribor). - V: M. Guštin (ur.), Zgodnji Slovani. Zgodnjesrednjeveška lončenina na obrobju vzhodnih Alp / Die frühen Slaven. Frühmittelalterliche Keramik am Rand der Ostalpen, 67-75, Ljubljana.

CORNAGGIA CASTIGLIONE, O. 1956, Origini e distribuzione delle pintaderas preistoriche ,euro-asiatiche‘. - Rivista Firenze 11, 109-192.

DIMITRIJEVIĆ, S. 1961, Problem neolita i eneolita u sjeverozapadnoj Jugoslaviji (Problem des Neolithikums und Äeneolithikums in Nordwestjugoslawien). - Opuscula Archaeologica 5.

DOLINAR, N. 2016, Neo/eneolitska jama iz Kranja [Neo-eneolithic pit from Kranj]. -Diplomska naloga / MA Thesis, Oddelek za arheologijo, Filozofska fakulteta Univerze v Ljubljani (neobjavljeno / unpublished).

DULAR, J. 2001, Neolitska in eneolitska višinska naselja v osrednji Sloveniji (Neolithische und äneolithische Höhensiedlungen in Zentralslowenien). - Arheološki vestnik 52, 89-106.

DULAR et al. $1991=$ J. Dular, B. Križ, D. Svoljšak, S. Tecco Hvala 1991, Utrjena prazgodovinska naselja v Mirenski in Temeniški dolini / Befestigte prähistorische
Siedlungen in der Mirenska dolina und der Temeniška dolina. - Arheološki vestnik 42, 65-198.

GREIF, T. 1997-1998, Prazgodovinska kolišča Ljubljanskega barja. Arheološka interpretacija in poskus rekonstrukcije načina življenja (The prehistoric pile dwellings in the Ljubljansko barje. An archaeological interpretation and attempted reconstruction of the way of life). - Arheo 18.

GUŠTIN, M. (ur.) 2005a, Prvi poljedelci. Savska skupina lengyelske kulture / First farmers. The Sava group of the Lengyel culture. - Annales Mediterranea, Koper.

GUŠTIN, M. 2005b, Savska skupina lengyelske kulture / The Sava group of the Lengyel culture. - V: Guštin (ur.) 2005a, 7-22.

GUŠTIN, M., A. TOMAŽ, B. KAVUR 2005, Drulovka pri Kranju (Drulovka near Kranj). - V: Guštin (ur.) 2005a, 37-62.

GUŠTIN et al. $2017=$ M. Guštin, G. Tiefengraber, D. Pavlovič, M. Zorko 2017, Nova Tabla pri Murski Soboti. Prazgodovina. - Arheologija na avtocestah Slovenije 52/1. [https://www.zvkds.si/sites/www.zvkds.si/files/uploads/ files/publication/nova_tabla_-_prazgodovina_web.pdf].

HAREJ, Z. 1976, Kolišče v Notranjih Goricah (Der Pfahlbau in Notranje Gorice). - Poročilo o raziskovanju paleolita, neolita in eneolita $v$ Sloveniji 5, 95-117.

HOMEN, Z. 1985, Prilog proučevanju lasinjskih keramičkih bočica. - Muzejski vjesnik 8, 44-46.

HORVAT, Ma. 1986, Ajdovska jama pri Nemški vasi - desni hodnik (Die Höhle Ajdovska jama bei Nemška vas - der rechte Gang). - Poročilo o raziskovanju paleolita, neolita in eneolita $v$ Sloveniji 14, 77-88.

HORVAT, M. 1989, Ajdovska jama pri Nemški vasi [Ajdovska jama bei Nemška vas]. - Razprave filozofske fakultete, Ljubljana.

HORVAT, M. 2005, Col 1 pri Podgračenem (Col 1 near Podgračeno). Tipološka opredelitev neolitskega keramičnega zbira SE 002/1/1. - V: Guštin (ur.) 2005a, 145-153.

HORVAT, M. 2009, Prvi prebivalci v Posavju. - V: J. Peternel (ur.), Ukročena lepotica - Sava in njene zgodbe, 25-35, Sevnica.

HORVAT, M., Ma. HORVAT 1987, Ajdovska jama pri Nemški vasi. - Varstvo spomenikov 29, 234-236.

HORVÁTH, L. A. 1996, Die Balaton-Lasinja Kultur und ihre südlichen Beziehungen. - V: F. Drașovean (ur.), The Vinča culture, its role and cultural connections. International Symposium on the Vinča Culture, its Role and Cultural Connections, Timișoara 1996, 335-350, Timișoara.

HORVÁTH, L. A. 2002, Die siedlung der Balaton-Lasinja-Kultur in Zalaegerszeg-Andráshida, Friedhof (Komitat Zala, Ungarm). - Antaeus 25, 255-282.

HORVÁTH, L. A., H. S. KATALIN 2003, Das Neolithikum und die Kupferzeit in Südwesttransdanubien. Siedlungsgeschichte und Forshungsstand. - Inventaria praehistorica Hungariae 9.

HORVÁTH, L. A., H. S. KATALIN 2004, Kupferzeitliche Siedlungen auf dem Fundort Dobri-Also-mező. - Zalai Muzeum 13, 55-118.

KAJZER CAFNIK, M., P. PREDAN 2006, Spodnje Hoče. - Varstvo spomenikov. Poročila 42 (2005), 141-142.

KALICZ, N. 1973, Über die chronologische Stellung der Balaton-Gruppe in Ungarn. - Symposium über die Ent- 
stehung und Chronologie der Badener Kultur, 131-167, Bratislava.

KALICZ, N. 1975, Siedlungsfunde der Balaton-Gruppe in Nagykanizsa. - Mitteilungen des Archäologischen Instituts der Ungarischen Akademie der Wissenschaften 4 (1973), 19-24.

KALICZ, N. 1991: Beitrage zur Kenntnis der Kupferzeit im ungarischen Transdanubien. - V: J. Lichardus (ur.), Die Kupferzeit als historische Epoche. Symposium Saarbrüchen und Otzenhausen (1988), Saarbrücker Beiträge zur Altertumskunde 55/1, 347-387.

KALIZC, N. 2003, Az újkőkorvégi és rézkori megtelepedés maradványai a nagykanizsai Inkey-kápolna mellett (Kr.e. 5.évezred első harmadától a 3. évezred alső feléig). Zalai Múzeum 12, 7-49.

KAVUR, B. 2010, Polomljena kolesa in pozabljene živali. Odsevi predmetov na razpotjih kultur (Broken wheels and forgotten animals. Reflection of artifacts on the crossroads of cultures). - Zbornik soboškega muzeja $15,63-75$.

KAVUR, B., A. TOMAŽ, Z. MILEUSNIĆ 2006, Sodolek naselje Bakrene dobe. - V: Tomaž (ur.) 2006, 121-128.

KERMAN, B. 2013, Kalinovnjek pri Turnišču. - Arheologija na avtocestah Slovenije 33 [http://www. zvkds.si/sites/ www.zvkds.si/files/uploads/files/publication/33_kalinovnjek_pri_turniscu.pdf].

KOROŠEC, J. 1956, Neolitična naselbina v Drulovki pri Kranju (Eine neolitische Siedlung in Drulovka bei Kranj). - Arheološki vestnik 7, 3-28.

KOROŠEC, J. 1958-1959, Miniaturne steklenice v neolitu Jugoslavije. - Arheološki vestnik 9-10, 3-12.

KOROŠEC, J. 1960, Drulovka. - Zbornik Filozofske fakultete III/4.

KOROŠEC, J. 1965, Neo- in eneolitski elementi na Ptujskem gradu (Neolithische und eneolithische Elemente auf dem Ptujski grad (die Burg von Ptuj)). - Poročilo o raziskovanju neolita in eneolita $v$ Sloveniji 2, 5-53.

KOROŠEC, P. 1975, Poročilo o raziskavah v Ajdovski jami 1967. leta (Bericht über die Forschungen in der Ajdovska Höhle im J. 1967). - Poročilo o raziskovanju neolita in eneolita $v$ Sloveniji 4, 170-187.

KRAMBERGER, B. 2010, Zgornje Radvanje, Cluster 10 - a Late Neolithic pit with a structure and smaller pits. Documenta Praehistorica 37, 311-337.

KRAMBERGER, B. 2014a, The Neolithic/Eneolithic sequence and pottery assemblages in the fifth millennium BC in north-eastern Slovenia. - Documenta Praehistorica 41, 237-282.

KRAMBERGER, B. 2014b, Naselbinske strukture in keramični zbiri $v$ petem tisočletju pred našim štetjem $v$ severovzhodni Sloveniji (Settlement structures and pottery assemblages in the fifth millennium BC in Northeastern Slovenia). - Doktorska disertacija / Dissertation, Oddelek za arheologijo, Filozofska fakulteta Univerze v Ljubljani (neobjavljeno / unpublished).

KRAMBERGER, B. 2015a, Forms, function, and use of Early Eneolithic pottery and settlement structures from Zgornje Radvanje, Slovenia. - Documenta Praehistorica 42, 231-250.

KRAMBERGER, B. 2015b, Svetilka iz zgodnjeeneolitske naselbine Zgornje Radvanje v Mariboru / Eine Lampe aus der früh-äneolithischen Siedlung von Zgornje Radvanje in Maribor. - Arheološki vestnik 66, 57-81.

KRAMBERGER, B. 2018, Najdbe in sledovi poselitve iz bakrene dobe pod gomilo v Brezju pod Brinjevo goro / Funde und Besiedlungsspuren aus der Kupferzeit unter dem Grabhügel in Brezje unterhalb der Brinjeva gora. - Arheološki vestnik 69, 69-133.

LUBŠINA TUŠEK, M. 1990, Neolit in eneolit v severovzhodni Sloveniji. - Diplomska naloga / PhD Thesis, Oddelek za arheologijo, Filozofska fakulteta Univerze v Ljubljani (neobjavljeno / unpublished).

LUBŠINA TUŠEK, M. 1993, Kamnito orodje v severovzhodni Sloveniji (The stoneaxes of northeastern Slovenia). - V: B. Lamut (ur.), Ptujski arheološki zbornik ob 100-letnici muzeja in Muzejskega društva, 31-158, Ptuj.

LUBŠINA TUŠEK, M. 2004, Izročilo preteklosti med Potrčevo in Volkmerjevo cesto na Ptuju (Überlieferung der Vergangenheit zwischen der Potrč und Volkmer Straße). - V: Zbornik Splošne bolnišnice dr. Jožeta Potrča Ptuj, 1874-2004, 73-79, Ptuj.

MAKKAY, J. 1984, Early Stamp Seals in South - East Europe. - Budimpešta.

MARKOVIĆ, Z. 1985, Pogrebni običaji i društveno raslojevanje u neolitu, eneolitu i početku brončanog doba sjeverne Hrvatske. - Podravski zbornik 11 (85), 157-167.

MARKOVIĆ, Z. 1994, Sjeverna Hrvatska od neolita do brončanog doba. - Koprivnica.

MEDOVIĆ, I. 2012, Neolitske kultne posude iz srednjeg Banata. - Rad Muzeja Vojvodine 54, 23-49.

MINICHREITER, K., Z. MARKOVIĆ 2013, Beketinci Bentež, naselja iz eneolitika, ranoga i kasnoga srednjega vijeka. - Monografije Instituta za arheologiju 3.

MIOĆ, P., M. ŽNIDARČIČ 1988, Osnovna geološka karta SFRJ 1 : 100 000. Tolmač za lista Maribor in Leibnitz. - Beograd.

MURKO, M., P. PREDAN 2010, Poročilo o predhodnih arheoloških raziskavah - arheološko dokumentiranje ob izvedbi drenaže okoli starega župnišča v Hočah. - Neobjavljeno poročilo / Unpublished report (hrani: Primož Predan, PJP d.o.o; ZVKD MB, OE Maribor).

NOVŠAK, M., A. TOMAŽ, A. PLESTENJAK 2013, Brezje pri Turnišču. - Arheologija na avtocestah Slovenije 40 [https://www.zvkds.si/sites/www.zvkds.si/files/uploads/ files/publication/40_brezje_pri_turniscu.pdf].

OBEREDER, J. 1989, Die jungneolitische Siedlung Raababerg bei Graz. - Diplomska naloga / PhD Thesis, Universität Wien (neobjavljeno / unpublished).

PAHIČ, S. 1955, Prazgodovinska seliščna najdba v Zrečah (Urgeschichtliche Fundstelle in Zreče). - Arheološki vestnik $6,258-263$.

PAHIČ, S. 1956, Neolitske jame v Brezju pri Zrečah (Neolithische Siedlungsreste in Brezje bei Zreče). - Arheološki vestnik 7/3, 227-241.

PAHIČ, S. 1973, Najstarejše seliščne najdbe v Severovzhodni Sloveniji (Die ältesten Siedlungsfunde in Nordostslowenien). - Arheološki vestnik 24, 12-30.

PAHIČ, S. 1976, Seliščne najdbe v zahodnih Slovenskih goricah - Andrenci, Spodnji Duplek, Spodnji Porčič, Vumpah (Siedlungsfunde in den westlichen Slovenske gorice - Andrenci, Spodnji Duplek, Spodnji Porčič, 
Vumpah). - Poročilo o raziskovanju paleolita, neolita in eneolita $v$ Sloveniji 5, 29-83.

PAHIČ, V. 1983, Zbelovo. - Poročilo o raziskovanju paleolita, neolita in eneolita $v$ Sloveniji 11, 85-137.

PAK, M. 1964, Današnji gospodarski pomen izgonov na Zgornjem Dravskem polju. - Geografski vestnik 36, 75-79.

PAK, M. 1998, Dravska ravan. - V: D. Perko, M. Orožen Adamič (ur.), Slovenija - pokrajine in ljudje, 592-605, Ljubljana.

PARZINGER, H. 1984, Die stellung der Uferrandsiedlungen bei Ljubljana im Äneolithischen und Frühbronzezeitlichen Kultursystem der Mittleren Donauländer. - Arheološki vestnik 35, 13-63.

PAVLIN, P. 2006, Grac pri Selih pri Zajčjem vrhu. - V: Tomaž (ur.) 2006, 211-227.

PAVLIN, P., J. DULAR 2007, Prazgodovinska višinska naselja v Posavskem hribovju (Prehistoric hilltop settlements in the Posavje Hills). - Arheološki vestnik 58, 65-120.

PLESTENJAK, A. 2010, Gorice pri Turnišču. - Arheologija na avtocestah Slovenije 12 [https://www.zvkds.si/sites/ www.zvkds.si/files/uploads/files/publication/012_gorice_pri_turniscu_.pdf].

PREDAN, P. 2012, Poročilo o arheoloških raziskavah - arheološka izkopavanja ob gradnji zadrževalnika visokih vod Hoče in sekundarnega fekalnega kanala, na parceli 762/2 k.o. Spodnje Hoče, EŠD 10328-Hoče naselbina. - Neobjavljeno poročilo / Unpublished report (hrani: Primož Predan, PJP d.o.o; ZVKD MB, OE Maribor).

PREDAN, P. 2017, Poročilo o predhodnih arheoloških raziskavah (arheološkem testnem izkopu) zaradi gradnje trgovskega objekta na parc. št. 768/2, 765, 766, 767, vse k.o. Spodnje Hoče. - Neobjavljeno poročilo / Unpublished report (hrani: Primož Predan, PJP d.o.o; ZVKD MB, OE Maribor).

PREDAN, P., G. ČAKŠ 2012, Poročilo o arheološkem nadzoru ob rušitvi in novogradnji stanovanjske stavbe, na parc. št. 633/1, k.o. Spodnje Hoče. - Neobjavljeno poročilo / Unpublished report (hrani: Primož Predan, PJP d.o.o; ZVKD MB, OE Maribor).

RAVNIK, M., G. TICA 2018, Ponikve pri Trebnjem. Arheologija na avtocestah Slovenije 57 [http://www. zvkds.si/sites/www.zvkds.si/files/uploads/files/publication/57_ponikve_pri_trebnjem.pdf].

RUTTKAY, E. 1993-1994, Neues Tonstempel der Kanzianiberg-Lasinja-Gruppe. - Mitteilungen der Antropologischen Gesellschaft in Wien 123/124, 221-238.

SAGADIN, M. 2005, Nekatere neolitske najdbe z vzhodne Gorenjske (Some Neolithic finds from the Eastern Gorenjska). - V: Guštin (ur.) 2005a, 29-36.

SAMONIG, B. 2003, Studien zur Pfahlbauforschung in Österreich. Materialen II. Die Pfahlbaustation des Keutschacher Sees. - Mitteilungen der Prähistorischen Kommission der Österreichischen Akademie der Wissenschaften 51.

SRAKA, M. 2012, 14C calendar chronologies and cultural sequences in 5th millennium calBC in Slovenia and neighbouring regions. - Documenta Praehistorica 39, 349-376.

SRAKA, M. 2014, Bayesian modeling the 14C calendar chronologies of the Neolithic-Eneolithic transition. Case studies from Slovenia and Croatia. - V: W. Schier, F. Draşovean (ur.), The Neolithic and Eneolithic in southeast Europe. New approaches to dating and cultural dynamics in the 6th to 4 th millennium $B C$, Prähistorische Archäologie in Südosteuropa 28, 369-396.

STRAUB, P. 2006, Középső rézkori település Sormás határában / Middle Copper age settlement at Sormás. - V: Régészeti Kutatások Magyarországon 2005 / Archaeological Investigations in Hungary 2005, 33-60, Budimpešta.

STRMČNIK GULIČ, M. 1989, Hoče. - Varstvo spomenikov 31, 224-226.

STRMČNIK GULIČ, M. 1990a, Hoče. - Varstvo spomenikov 32, 173-175.

STRMČNIK GULIČ, M. 1990b, Podoba antične poselitve med vzhodnim Pohorjem in Dravo. - Arheološki vestnik 41, 135-146.

STRMČNIK GULIČ, M. 1996, Novosti o arheološkem bogastvu Hoč. - V: J. Fridl et al. (ur.), Hoče - 850, Območje hoške pražupnije 1, 105-126, Hoče.

STRMČNIK GULIČ, M. 2003, Spodnje Hoče. - V: B. Djurić, D. Prešeren (ur.), Zemlja pod vašimi nogami. Arheologija na avtocestah Slovenije. Vodnik po najdiščih, 242-243, Ljubljana.

STRMČNIK GULIČ, M. 2006, Malečnik - arheološko najdišče. - V: Tomaž (ur.) 2006, 195-202.

ŠAVEL, I. 1984, Poročilo o raziskovanju od leta 1981-1983 v Šafarskem (Bericht über die Forschungen in Šafarsko in den Jahren 1981-1983. - Poročilo o raziskovanju paleolita, neolita in eneolita $v$ Sloveniji 1, 39-71.

ŠAVEL, I. 1992, Bukovnica - rezultati terenskih raziskav v letih 1987-1988 (Bukovnica - Resultate der Ausgrabungen in den Jahren 1987-1988). - Poročilo o raziskovanju paleolita, neolita in eneolita $v$ Sloveniji 20, 57-85.

ŠAVEL, I. 1994, Prazgodovinske naselbine $v$ Pomurju (Prehistoric Settlements in Pomurje). - Murska Sobota.

ŠAVEL, I. 2006, Prekmurje v mlajši kameni dobi (Prekmurje in the Late Stone Age). - V: Tomaž (ur.) 2006, 89-94.

ŠAVEL, I., Š. KARO 2012, Popava pri Lipovcih 1. - Arheologija na avtocestah Slovenije 30 [https://www.zvkds.si/ sites/www.zvkds.si/files/uploads/files/publication/30_popava_pri_lipovcih_1.pdf].

ŠAVEL, I., S. SANKOVIČ 2011, Pri Muri pri Lendavi. - Arheologija na avtocestah Slovenije 23 [https:// www.zvkds.si/sites/www.zvkds.si/files/uploads/files/ publication/23-pri_muri_pri_lendavi.pdf].

ŠOBERL et al. 2014 = L. Šoberl, Mi. Horvat, A. Žibrat Gašparič, M. Sraka, R. Evershed, M. Budja 2014, Neolithic and Eneolithic activities inferred from organic residue analysis of pottery from Mala Triglavca, Moverna vas and Ajdovska jama, Slovenia. - Documenta Praehistorica 41, 149-179.

TEŽAK-GREGL, T. 2001, The lengyel culture in Croatia. - V: J. Regenye (ur.), Sites and stones: Lengyel culture in western Hungary and beyond. A review of the current research, 27-35, Vézprem.

TEŽAK-GREGL, T. 2005, Ozalj-Stari grad, neolitička naseobina. - V: Guštin (ur.) 2005a, 155-162.

TIEFENGRABER, G. 2004, Jungneolithische Funde vom Rabenstein bei St. Paul im Lavanttal. - Carinthia I 194, 185-254.

TIEFENGRABER, G. 2006, Jungneolitische funde aus Čatež-Sredno polje (Mlajše neolitske in eneolitske najdbe iz Čateža-Srednega polja). - V: Tomaž (ur.) 2006, 229-234.

TIEFENGRABER, G. 2018, Der Wildoner Schlossberg. Die Ausgrabungen des Landesmuseums Joanneum 1985-1988. 
- Forschungen zur geschichtlichen Landeskunde der Steiemark 80, Schild von Steier 7.

TOMANIČ-JEVREMOV, M., A. TOMAŽ, B. KAVUR 2006a, Neolitske in bakrenodobne najdbe s Ptujskega gradu (Neolithic and Copper Age finds from Ptuj Castle). - V: Tomaž (ur.) 2006, 175-194.

TOMANIČ-JEVREMOV, M., A. TOMAŽ, B. KAVUR 2006b, Ormož-Škoršičev vrt, bakrenodobna jama (Ormož-Škoršičev vrt, a Copper Age pit). - V: Tomaž (ur.) 2006, 155-174.

TOMAŽ, A. 1999, Časovna in prostorska strukturiranost neolitskega lončarstva: Bela krajina, Ljubljansko barje, Dinarski kras. - Magistrsko delo / Master thesis, Oddelek za arheologijo, Filozofska fakulteta Univerze v Ljubljani (neobjavljeno / unpublished).

TOMAŽ, A. (ur.) 2006, Od Sopota do Lengyela. Prispevki o kamenodobnih in bakrenodobnih kulturah med Savo in Donavo / Between Sopot and Lengyel. Contributions to Stone Age and Copper Age Cultures between the Sava and the Danube. - Annales Mediterranea, Koper.

TOMAŽ, A. 2010, Neolitska keramika iz najdišča Čatež-Sredno polje: prispevek k poznavanju neolitskega obdobja $v$ osrednji Sloveniji (Neolithic pottery from the Čatež-Sredno polje: a contribution to our knowledge about the neolithic period in central Slovenia). - Doktorska disertacija / Dissertation, Univerza na Primorskem Fakulteta za humanistične študije Koper (neobjavljeno / unpublished).

TOMAŽ, A. 2012, Turnišče. - Arheologija na avtocestah Slovenije 28 [https://www.zvkds.si/sites/www.zvkds.si/ files/uploads/files/publication/28_turnisce.pdf].

TURK, J. 2009, Petrološka sestava in izvor kamnitih najdb $\mathrm{z}$ najdišč Stare gmajne in Blatna Brezovica. - V: A. Velušček (ur.), Koliščarska naselbina Stare gmajne in njen čas / Stare gmajne pile-dwelling settlement and its era, Opera Instituti Archaeologici Sloveniae 16, 281-286.

TUŠEK, I., B. KAVUR 2011, Ivankovci (Ivánkóc) pri Lendavi. - Arheologija na avtocestah Slovenije 15 [https:// www.zvkds.si/sites/www.zvkds.si/files/uploads/files/ publication/ivankovci_pri_lendavi.pdf].

VELUŠČEK, A. 2005, Kratna nad Kamnikom, Gradišče pri Stiški vasi (Kratna above Kamnik, Gradišče near Stiška vas. - V: Guštin (ur.) 2005a, 23-28.
VELUŠČEK, A. 2006, Resnikov prekop - sondiranje, arheološke najdbe, kulturna opredelitev in časovna uvrstitev / Resnikov prekop - Sample Trenching, Archaeological Finds, Cultural and Chronological Classification. - V: A. Velušček (ur.), Resnikov prekop, najstarejša koliščarska naselbina na Ljubljanskem barju / Resnikov prekop, the oldest Pile-Dwelling Settlement in the Ljubljansko Barje, Opera Instituti Archaeologici Sloveniae 10, 19-85.

VELUŠČEK, A. 2011a, Spaha in kronologija osrednje- in južnoslovenskega neolitika ter zgodnejšega eneolitika / Spaha and chronology of central and south Slovenian Neolithic and Early Eneolithic. - V: A. Velušček (ur.), Spaha, Opera Instituti Archaeologici Sloveniae 22, 201-243.

VELUŠČEK, A. 2011b, Spaha: Predstavitev in tipologija arheoloških najdb / Presentation and typology of archaeological finds. - V: A. Velušček (ur.), Spaha, Opera Instituti Archaeologici Sloveniae 22, 105-200.

VINDER, J. 2011, Spodnje Hoče, Zgodnjesrednjeveška naselbina. - Diplomska naloga / MA Thesis, Filozofska Fakulteta Univerze v Ljubljani (neobjavljeno / unpublished).

VINDER, J. 2016, Poročilo o arheoloških izkopavanjih na območju dozidave trgovskega objekta Hofer Hoče, na parc. št. 650/3, k.o. Spodnje Hoče. - Neobjavljeno poročilo / Unpublished report (hrani: Primož Predan, PJP d.o.o; ZVKD MB, OE Maribor).

VINDER, J. 2018, Poročilo o arheoloških raziskavah ob gradnji trgovskega objekta Hoče na parc. štev. 761/1, 768/2, 765, 766, 767, vse k.o. Spodnje Hoče. - Neobjavljeno poročilo / Unpublished report (hrani: Primož Predan, PJP d.o.o; ZVKD MB, OE Maribor).

VIRÁG, S. M. 2005, Középső rézkori kerámialeletek Zalavár-Basaszigetről (A Balaton-Lasinja kultúra tipológiájának és belső kronológiájának kérdéseiről. - Zalai Múzeum 14, 37-52.

ŽIŽEK, I. 2006a, Hajndl pri Ormožu, naselje bakrene dobe (Hajndl near Omož, A Copper Age settlement. - V: Tomaž (ur.) 2006, 141-227.

ŽIŽEK, I. 2006b, Eneolitska naselbina Hardek (The Copper Age settlement at Hardek). - V: Tomaž (ur.) 2006, 129-140.

ŽNIDARČIČ, M., P. MIOĆ 1988, Osnovna geološka karta SFRJ 1 : 100 000, list Maribor in Leibnitz. - Beograd. 


\title{
Settlement remains from the Early Chalcolithic period in Hoče (Slovenia)
}

\author{
Summary
}

The archaeological site is situated below Pohorje at an altitude of between $278.2 \mathrm{~m}$ and $279.9 \mathrm{~m}$ in the centre of Spodnje Hoče near Maribor, at the junction of the Hočki potok stream valley with the extensive Drava Basin.

Excavations (conducted by the Institute for the Protection of the Cultural Heritage of Slovenia and the private company Pjp, d.o.o.) between 1988 and 2018 in Hoče showed that the area was inhabited in the Copper Age, in the Late Bronze and Iron Age, then in the Roman period and again in the early Middle Ages. To date, the only larger collection of finds from this site was published by Mira Strmčnik Gulič, the head of the excavation in 1988-1989. She also published some ceramic finds from the Copper Age settlement and some stone artefacts, which were partly introduced already in 1993 by Marija Lubšina Tušek. The entire Copper Age pottery assemblage, however, was comprehensively processed by the author of this article.

Traces of a Copper Age settlement were discovered northwest of the St. George's Parish Church (sv. Jurij) in the centre of Spodnje Hoče in 1988 (Fig. 1), at the time of the construction of a larger building/workshop (Orglarska delavnica). In addition to settlement remains from the Early Copper Age, traces of the Late Bronze Age and the Roman settlements were discovered during excavations, which took place in the centre of Spodnje Hoče in 1988 and 1989. [Figs. 2-4; Fns. 3-5]

\section{Copper Age settlement pits}

Most of the Copper Age finds were excavated in 1989 (in three large pits, interpreted as the remains of pit-houses), and a part in 1988 (in three different pits west of the construction pit of 'Orglarska delavnica' building) (Figs. 4-6). The descriptions of the settlement pits are summarised in line with the descriptions of Strmčnik Gulič.

The settlement remains were discovered at a depth of between 0.6 and $1 \mathrm{~m}$.

Pit I (Fig. 5): Size: $2.2 \times 1.8 \mathrm{~m}$; interpreted as a storage pit. Finds: hammerstone made of serpentinite (Pl. 20: 10), silex, and individual pottery fragments.
Pit II (Fig. 5): Size: $5.41 \mathrm{~m}$ wide and $40-60 \mathrm{~cm}$ deep; interpreted as a pit-house. It partly spread out of the excavation area. The walls of the pit were sloping, the bottom uneven. Finds: 80 ceramic fragments (Pl. 20: 1-9).

Post-hole 7 (Fig. 5): Size: approx. diameter of $25 \mathrm{~cm}$. Finds: a vessel with a grip in the shape of a human-foot (Pl. 21:1) probably originates from it.

Pit-house I (Figs. 4; 6): consisted of three connected pits. Size: $6 \times 2.5$, around $30 \mathrm{~cm}$ deep. The central part was damaged by a wall from a building, on the west side by a limekiln; both structures are dating to the Roman period. A dark brown loam layer that contained fragments of burned clay daub, charcoal and pottery fragments was excavated. Finds: a total of 635 pottery fragments (Pls. 1-8; 9: 10). A small cone of serpentinite (a byproduct of drilling the hole in a stone axe) ( $P l$. 9: 11), a fragment of a stone axe made of a light white stone (Pl.9: 12), and another small fragment of the edge of an axe made of greyish-brownish stone were also found in the pit.

Pit-house II (Figs. 4; 6): A hexagonal pit. Size: $5.7 \times 3.5 \mathrm{~m}$ and a depth of up to $52 \mathrm{~cm}$. The bottom was uneven. The pit contained a dark brown layer with fragments of burnt clay daub, charcoal, bones, pottery fragments, and stone artefacts. Finds: 535 ceramic fragments (Pls. 10-15; 16: 1-10), a stone axe (Pl. $17: 1)$, a chisel (Pl. 16:14), three cones (Pl. 16: 11-13), a fragmented grinding stone ( $P l$. $17: 2)$, and probably a stone with a partially drilled hole (Pl. 17: 3), a stone axe with a hole and a cone belonging to it (Pl. 17: 4,5) [Fn. 19].

Pit-house III (Fig. 6): The third large pit was discovered under layers from the Roman period (Layer 2) and late Bronze Age (Layer 4). Size: $5.5 \times$ $4.6 \mathrm{~m}$. In the southern part, the pit extended out of the excavations area and in the central part under the lime kiln from the Roman era, under which the excavations did not take place. Two cultural layers and a cluster of burnt clay with charcoal were found in the pit. At the deepening on the bottom of the pit of a size $4.2 \times 2.2 \mathrm{~m}$ and a depth up to $26 \mathrm{~cm}$, Layer 9 was uncovered - covered in one part of the pit by a $60 \mathrm{~cm}$ wide and $10 \mathrm{~cm}$ thick concentration of a burnt clay and charcoal, which 
could present the remains of the hearth (Layer 8) $[F n .21]$ and the later was covered by Layer 5. Finds: the hammerstone $(P l .17: 8)$ and 184 pottery fragments (Pl. 17: 9-11; Pls. 18; 19). Among them a bowl (Pl. 18: 4), pot (Pl. 19: 5), and a similar pot (Pl. 19: 3). 'One example of a beautifully sharpened blade (small axe)' and a cone - the byproduct of drilling the hole in the stone axe are also recorded to be found in the pit-house III. According to the description of the objects and the excavation notes, it goes probably about the stone axe $P l .17: 7$, and about the cone at Pl. 17: 6 .

Four post-holes (10-13) were discovered at the edge of the pit. Finds: Post-hole 10, which was located on the west side of pit-house III, contained ceramic fragments that probably belong to the Early Copper Age, based on the pottery technology. The rest of the post-holes were without finds, but it is assumed that they could belong to the Copper Age as well, based on their location.

\section{Pottery assemblage}

The pottery of the Copper Age settlement in Spodnje Hoče belongs to the Lasinja culture. A total of 1584 fragments were found $(33.9 \mathrm{~kg})$. After the reconstruction process, 219 of these artefacts were analysed in detail, and 153 of them were included in the catalogue (see Katalog and Pls. 1-21). They were defined as parts of dishes, fragments of hollow pedestals (e.g. Pls. 1: 2-9; 10: 2; 11: 1-4; 17: 9), bowls, pots, fragments of pitchers (Pls. 3: 6-14; 13: 1-4,6; 20: 4,7), ladles (Pls. 9: 8-10; 16: 8; 19: 6), a baking plate ( $P l .18: 1)$, a small ceramic plate with a hole in the middle ( $P l .16: 10)$, a vessel with a grip in the shape of a human leg ( $P l .21: 1)$, a miniature bottle ( $P l$. 19: 4) and a cylindrical seal (Pl. 16: 9; Fig. 10: 5). The remaining pieces represent less typical ceramic fragments, mostly belly shards.

The ceramic objects were hand-made. The largest amount of them was produced from clay without inclusions (very fine-grained pottery fabrics: $74 \%$ ) or with individual grains of quartz (fine-grained pottery fabrics: $22 \%$ ). Before firing, the surface of objects was carefully treated, burnished (83\%) or, in some cases, coated $(7 \%)$ with a coating of red (Pls. 1: 3; 2: 4; 8: 2,3; 9: 6; 12: 1; 16: 6,10; Fig. 8: 1-3), reddish (Pl. 10:1;13:4,5;16:2) or very dark grey paint ( $P l .10: 5)$. Objects were then fired either in incomplete oxidising conditions $(76 \%)$ or in incomplete oxidising conditions with a reduced atmosphere at the end (24\%) [Fn. 23];
81 fragments were decorated $(37 \%)$. The ornaments (Fig. 7) were made before firing, most often by incisions (52\%: e.g. Pls. 1: 12; 2: 1,2,5,6; 3: $6,8-10,13,14$ ) or by impressions (15\%: Pl. 3: 7,15 ), often also in a combination of both techniques (15\%: e.g., Pl. 1: 10). Appliques are also common (14\%: e.g. Pls. 1: 1; 11: 5,6), and sometimes they appear together with the incisions (4\%: e.g. Pl. 2: 3,4).

Some ceramic forms, for example, dishes with tongue like appliques (e.g. Pl. 1: 1; 10: 1,3-5; 11: 5) and high hollow feet convex on the top (Pl. 10: 5), can be considered as general types of Lasinja Culture, because they can be found over the complete territory of its distribution. The appearance of other ceramic forms, however, can be traced in different regions. Regarding this, it was recognised, that most of the vessel forms and motifs represented at Hoče are common at Lasinja sites in Drava Basin, Dravinjske gorice, Raababerg and/or in southeastern Slovenia and Gorenjska. This is true, for example, for dishes with extracted spouts (Pl. 12: 4) [Fn. 25], dishes with thrown spouts (Pl. 3: 4) [Fns. 26 and 27], dishes with semi-circular spouts with a partition (Pl. 3: 2,3) [Fn. 28] and for fragments of a dish or a bowl that is decorated with two horizontal sets of impressions on the rim (Pl. 17: 10) [Fns. 32-33]. On the same territory can be found the best analogies also for bowls with shoulders that are decorated with bundles of vertical incisions (Pl. 2: 5,6), or in combinations of bundles of vertical incisions and rounded plastic appliques $(P l$. 2: 3) [Fn. 44], pitchers decorated with bundles of vertical incisions (Pls. 3: 6,8-10,13,14; 13: 1,2; 20: 4,7) [Fn. 54], and finally pots.

Pots are the most common vessel form at the Copper Age settlement in Spodnje Hoče and appear in different types. A quantitative analysis of the appearance of these types within the assemblage from Hoče and Lasinja sites in Slovenia, Austria and western Hungary was carried out. These are pots with a concave lower body and a long sloping neck (Fig. 9: GI), pots with a concave lower body and a cylindrical neck (Fig. 9: GII) and barrelshaped pots (Fig. 9: GV; Pls. 19: 3,5; 20: 6). In the GI group, in addition to pots with a concave lower body, shoulders and a long sloping neck (e.g. Pls. $4: 1,2 ; 5: 1-3 ; 6: 1,2)$, pots without shoulders and long sloping neck are included; while the GII group presents pots with cylindrical necks of different lengths [Fn. 49]. Pots with concave lower bodies and cylindrical or long sloping necks are often 
decorated, in particular, with bundles of vertical incisions or grooves (Pls. 5: 4; 7: 2; 13: 9-15; 16: 1 ) on their shoulders. Sometimes the ornament is supplemented by a horizontal set of impressions (Pl. 14: 1,2), or one (Pls. 4: 2; 5: 2,3; 6:1) or two (Pls. 7: 6; 15:2) horizontal grooves/incisions, or the horizontal grooves extended all the way to the rim (Pl. 6: 2; 9: 3; 7: 1). In contrast, the pots of group GV are undecorated.

In the analysis were included those Lasinja sites on the territory of Slovenia, Austrian Styria, and western Hungary, from which are published at least five pots with entirely preserved profiles in the upper part. The analysis showed that only a few such sites are available (see List 1 to Fig. 9). In the case of the 'Šolski center' site in Ptuj, all the material was included in the study, which means that the pots could partly date also to the $45^{\text {th }}$ century BC. Moreover, from the pottery assemblage Ajdovska jama near Krško, we included in the analysis also a pot from the lower layer of the 'Right Cave corridor', which is by some researchers supposed to be earlier than the Lasinja culture [Fn. 50].

Two types of pots with concave lower bodies GI with a long sloping neck (45\%) and GII with cylindrical necks (35\%) dominate in the ceramic assemblage from Spodnje Hoče (Fig. 9: 18). At the nearby settlement of Zgornje Radvanje (Fig. 9: $17)$, pots with concave lower body and cylindrical necks dominate (GII: 74\%), less frequent are pots with long sloping necks (GI: 16\%); a similar ratio is shown by the analysis of pots in Ptuj - Šolski center (Fig. 9: 22 - GI: 13\%; GII: 74\%). In Raababerg in the neighbouring Austrian Styria, pots with high shoulders and short cylindrical necks dominate (Fig. 9: 29 - GII: 91\%), in Ajdovska jama cave, pots with long sloping necks are the most common (Fig. 9: 7 - GI: 57\%).

In contrast to the pots with long sloping necks (GI) and with cylindrical necks (GII), the barrelshaped pots (the GV group) are not known at the sites of Lasinja culture in the Dolenjska and Gorenjska regions. They occur individually at the sites at outskirts of Pohorje and at Haloze (Figs. 9: $15,16)$ but are predominant in the Lasinja sites of the Prekmurje region (Figs. 9: 32,33,37) and at the Lasinja sites in western Hungary (Figs. 9: 39,41). Several examples are also known from Austrian and Croatian sites of Lasinja Culture [Fn. 53].

\section{Cylinder seal}

Particular attention was paid to the cylinder seal from Spodnje Hoče. The central part of the seal's surface is made with 17 parallel incisions, one of the edges with short incisions that are transverse to the incisions in the central part and the other edge with zigzag incisions ( $P l .16$ : 9; Fig. 10: 5). Cylinder seals from the $5^{\text {th }}$ millennium BC sites in Austrian Styria were studied by Elisabeth Ruttkay and identified as belonging to the Lasinja Culture [Fn. 65]. In contrast, Mihael Budja studied cylinder seals from Slovenian sites and, unlike Ruttkay, placed them in the late Neolithic period [Fn. 66].

In our opinion, the seal from Spodnje Hoče is the most similar to the specimen found during Schmid's excavations at Notranje gorice (Fig. 10: 6) $[\mathrm{Fn} .70]$, which was a multiphase pile dwelling, or there were several settlements from the time after the Lasinja culture (horizons Ljubljansko barje III-V and VII) at one location. The seal from Notranjske gorice must be than younger than the one from Hoče. However, similar seals are not known yet from other sites dating to the $4^{\text {th }}$ or $3^{\mathrm{d}}$ millennium BC in Slovenia [Fn. 71].

Regarding the decoration, the seal from Hoče is also related to the two completely preserved seals from the Late Neolithic and Chalcolithic site at Drulovka near Kranj. These seals from Drulovka are decorated with three and four parallel incisions and are without precise data about the finding location (Figs. 10: 2,3) [Fn. 72]. At this site, a large amount of pottery of Lasinja Culture and Sava group were discovered and few shards of pottery with furrow incisions, some researchers, however, classify the seals as characteristic finds of the Sava Group [Fn. 73]. At Spaha near Pregrad, a comparable seal, decorated with two parallel incisions was discovered (Fig. 10:4) in a mixed layer (probe 4; layer: 3; quadrant 1) with finds from the Late Neolithic Sava group and Lasinja cultures and horizon of pottery with furrow incisions [Fn. 74].

Cylinder seals are known in Slovenia also from Moverna vas, Zgornje Radvanje and Grac pri Selih pri Zajčjem vrhu. In Moverna vas, they were found in the $6^{\text {th }}$ settlement phase that dates between $44^{\text {th }}$ and $43^{\text {rd }}$ century BC [Fns. 75 and 67]. In Zgornje Radvanje, a seal (Fig. 10: 1) identical to the seals from Drulovka and Spaha was found in a pit with pottery typical of Lasinja culture (Structure 16; SE 929) [Fn. 76]. While the partly preserved seal 
from Grac pri Selih pri Zajčjem vrhu, decorated with seven incisions (Fig. 10: 7), originates from a layer 2 in probe 1 with an apparently homogeneous pottery assemblage dated to the Late Neolithic period [Fn. 77].

Although the above-mentioned sites of cylinder seals from Slovenia are cultural differently attributed and dated, we believe that, with the exception of Notranjske gorice, their ceramic assemblages are quite comparable and probably date similar. Furthermore, cylindrical seals are not known from the sites that belong to the end/final phase of the late Neolithic Sava group ( $4^{\text {th }}$ and $5^{\text {th }}$ settlement phases of Moverna vas, Structure 2 at the PtujŠolski Center and Ponikve near Trebnje) and are radiocarbon dated to the $45^{\text {th }}$ and first half of the $44^{\text {th }}$ century BC; although it cannot be excluded that the seals found in the mixed layers at Drulovka and Spaha date to this time. However, it can be concluded that they are so far, according to the current state of research, certainly not present at the sites of the Sava Group, which are dated to the first half of the $5^{\text {th }}$ millennium BC, as for example Resnikov prekop, Čatež - Sredno Polje, Dragomelj and the $2^{\text {nd }}$ settlement phase in Moverna vas [Fn. 78]. Based on the above, the cylinder seals appear in Slovenia in the second half of the $5^{\text {th }}$ millennium $\mathrm{BC}$, precisely at the time of the Lasinja culture and, eventually, they appear in the final phase of the Sava Group of the Lengyel culture.

\section{Conclusion}

The pottery assemblage of the Copper Age settlement in Hoče is, in both morphological and ornamental terms, most similar to the material from the contemporary Lasinja sites in Podravje and Dravinjske gorice (north-eastern Slovenia). Furthermore, it is closely related to the material from the sites in Dolenjska (south-eastern Slovenia) and Gorenjska (north-western Slovenia) and Raababerg bei Graz, especially in similarly shaped and decorated pots and pitchers, bowls with shoulders, dishes with spouts and generally in decorative motifs composed of bundles of vertical incisions and in combination with horizontal sets of impressions. At some of the sites at this territory, which extends from the Graz-Leibnitz Basin to Drava Basin in north-eastern Slovenia and further to north-western, central, and southeastern Slovenia similar cylinder seals have also been discovered, which are sometimes interpreted as relicts of contacts over long distances [Fn. 85].

It is also apparent that pottery at the Lasinja sites in Podravje, Dravinjske gorice and in south-eastern Slovenia has its predecessors at sites of the late Sava Group, dated to the $45^{\text {th }}$ and the first half of the $44^{\text {th }}$ century BC. This is reflected, for example, by the appearance of pots with cylindrical necks [Fn. 45], the dishes with semi-circular spouts with a partition [Fn. 30-31], dishes with thrown spouts [Fn. 29], and especially in the pottery decoration and motifs.

The connections between pottery from Hoče and material from sites in Prekmurje region are to recognise to a lesser extent. They are mainly shown by barrel-shaped pots and bowls with button-shaped grips on the rim from the pit-house III, which are common on the Lasinja sites in Pomurje (the Mura River region in Slovenia) and western Hungary, which is also confirmed by the statistical analysis in the case of pots. It is interesting to note that the barrel-shaped pots appear in Hungary for the first time in the late Lengyel culture and that they should have originated at the sites in the central Balkans [Fn. 86]. Button-shaped grips on the rims of bowls and dishes, which are common at Lasinja sites in Prekmurje and western Hungary, may also have origin there [Fn. 87].

Based on the above, it can be concluded that on the territory of present-day north-eastern Slovenia, during the transition to the Copper Age in the second half of the $5^{\text {th }}$ millennium $\mathrm{BC}$, the intertwining of different pottery traditions in the manufacture of pottery of Lasinja culture can be recognised. On the one hand, the pottery tradition of the Sava Group is recognisable, which is more pronounced at the Lasinja sites in the Podravje and Dravinjske gorice; on the other, the tradition of the Lengyel culture and influences from the Central Balkan, which are more pronounced at the sites in the Prekmurje region, are present.

A similar duality in the material culture can be seen already at the end of the first half of the $5^{\text {th }}$ millennium BC, which is reflected by the distribution of the Late Lengyel culture and the need for the definition of the Sava Group of the Lengyel culture. The latter one clearly reached also northeast Slovenia, which particularly demonstrates the site Stoperce in the Haloze region [Fn. 88].

Finally, more than 40 archaeological sites of the Lasinja Culture are known thus far in northeastern Slovenia, in contrast to the late Neolithic period, of which only a handful of sites are known 
[Fn. 84]. Based on this, the time of Lasinja Culture can be seen as the time of first intensive settlement activities on this territory, as we can call it a 'settlement boom'. It is too early to define the concrete reasons for the significant increase in the number of the sites in the second half of the $5^{\text {th }}$ millennium BC in north-eastern Slovenia, but, it is obvious that the 'settlement boom' coincides with the so-called 'metal boom', or the expansion of knowledge of metallurgy from south-eastern Europe [Fn. 89]. Overall, also the transition to the Chalcolithic period in north-eastern Slovenia should be seen as a series of gradual changes and in connection with complex interactions between different prehistoric communities, which could also include the arrival of new populations from elsewhere.
Bine Kramberger

Zavod za varstvo kulturne dediščine Slovenije Center za preventivno arheologijo

Vičava 5

SI-2250 Ptuj

bine.kramberger@zvkds.si

https://orcid.org/0000-0002-9964-2489

Slikovno gradivo: Sl. 1 (foto: Ivo Bizjak). - Sl. 3; 4 (foto: Ivan Tušek, ZVKDS, OE Maribor).

Illustrations: Fig. 1 (photo: Ivo Bizjak). - Figs. 3; 4 (photo: Ivan Tušek, ZVKDS, OE Maribor). 

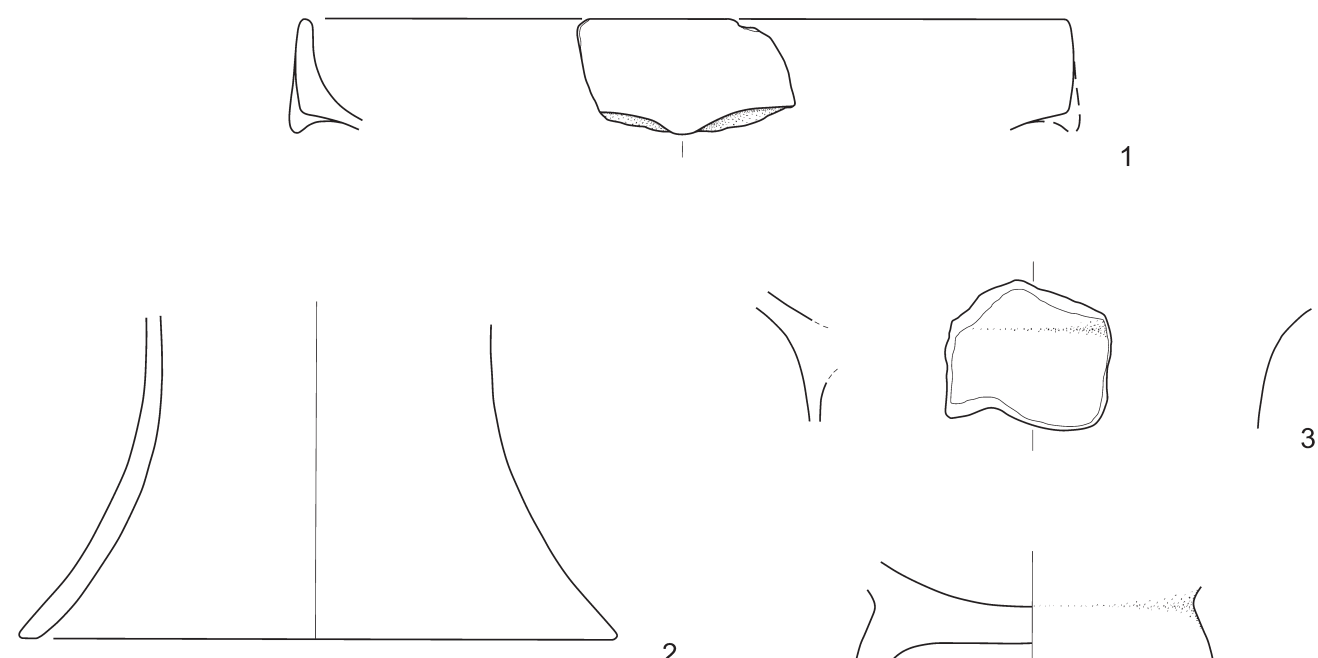

2
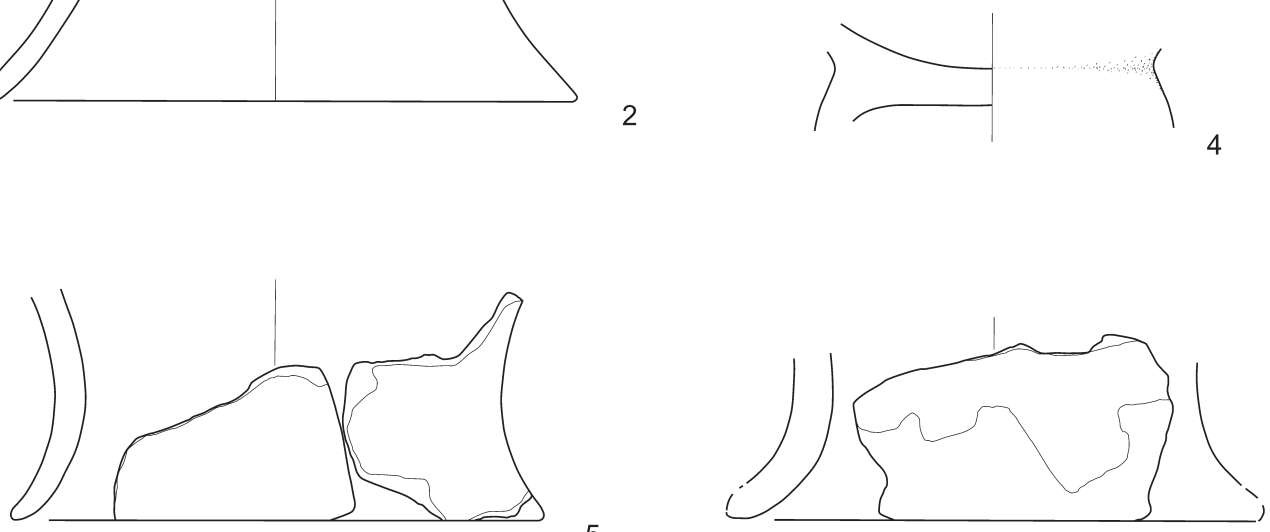

5
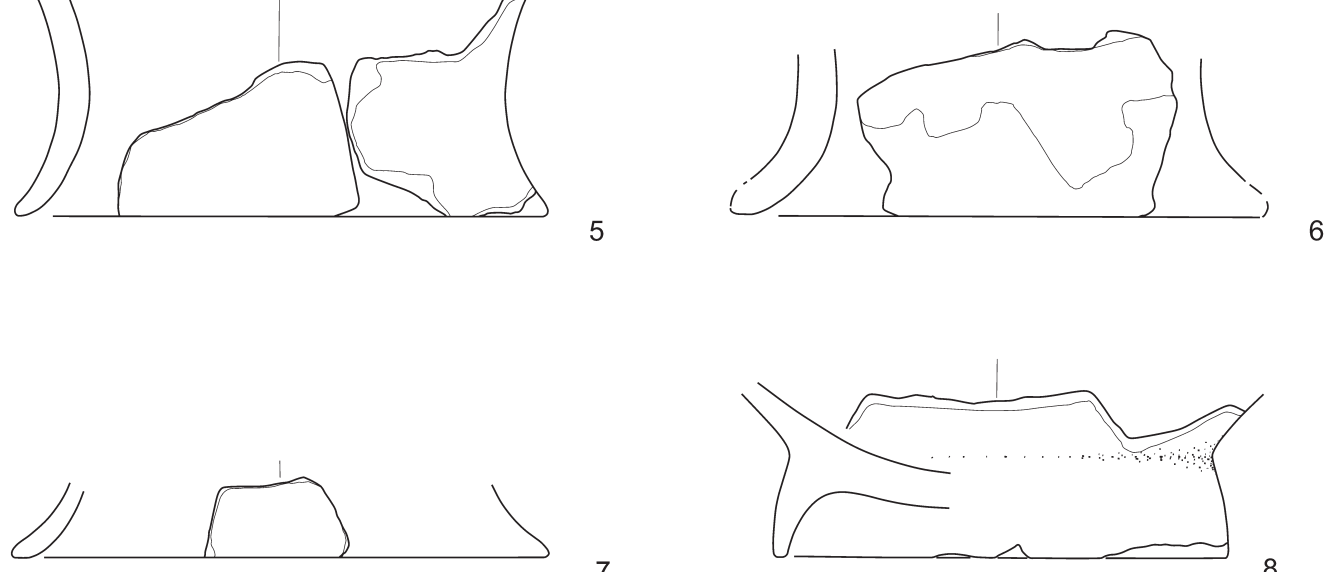

7
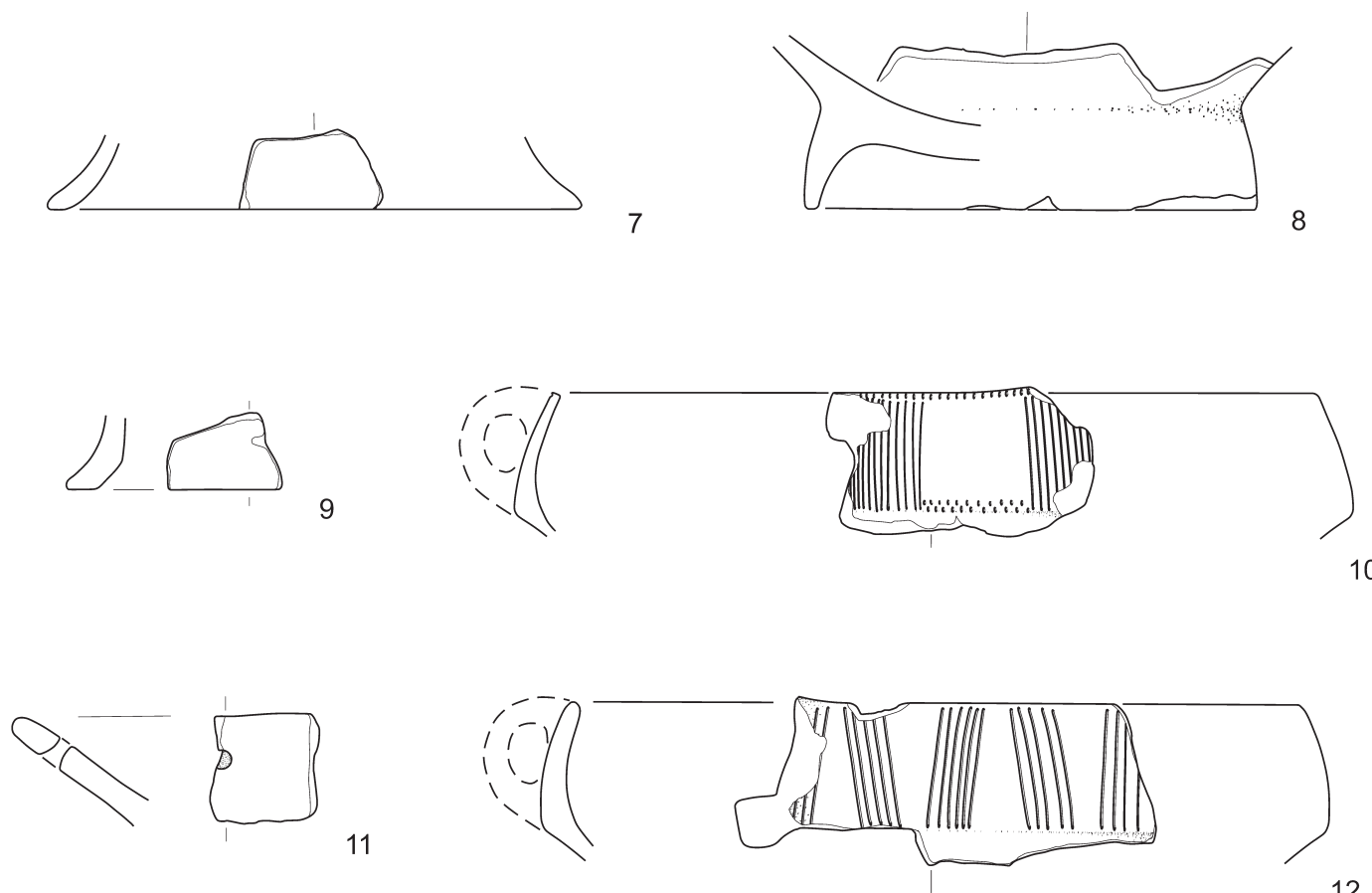

T. 1: Spodnje Hoče - Orglarska delavnica. Zemljanka I (1989). Vse keramika. M. = 1:3.

Pl. 1: Spodnje Hoče - Orglarska delavnica. Pit-house I (1989). All pottery. Scale = 1:3. 

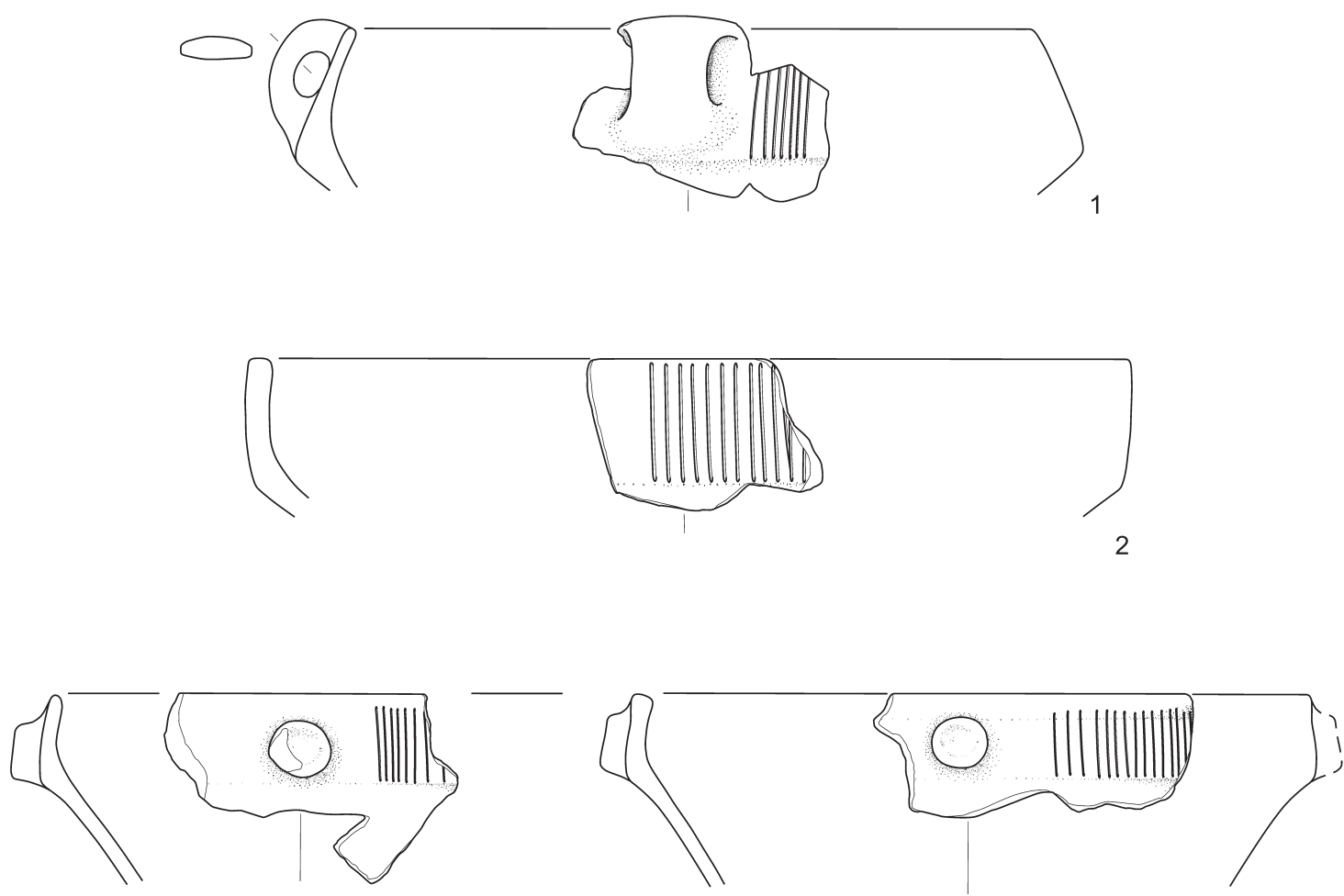

3
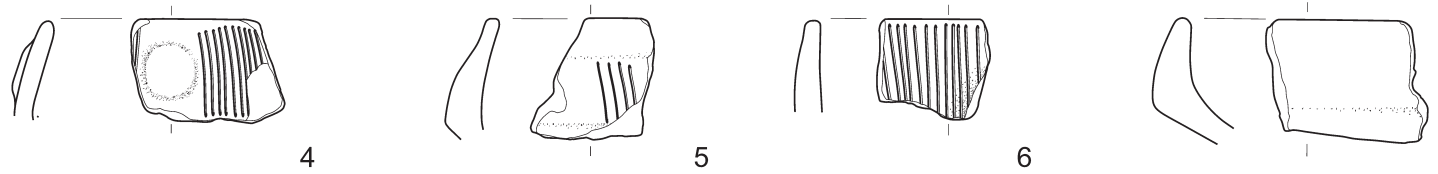

4

5

6
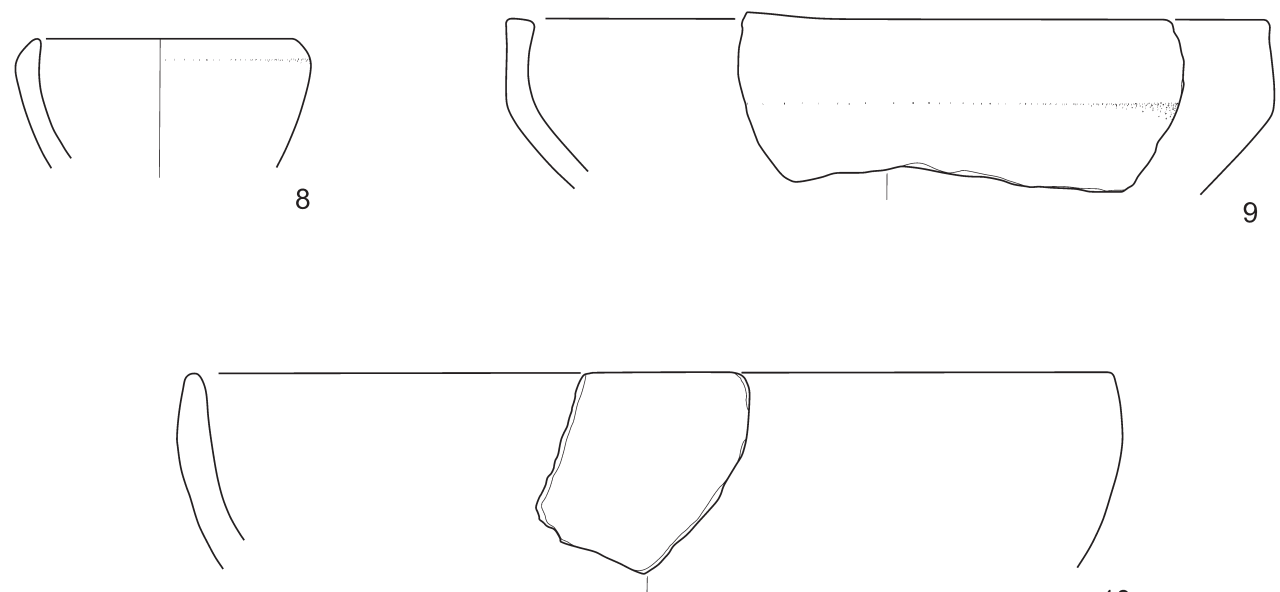

T. 2: Spodnje Hoče - Orglarska delavnica. Zemljanka I (1989). Vse keramika. M. = 1:3.

Pl. 2: Spodnje Hoče - Orglarska delavnica. Pit-house I (1989). All pottery. Scale = 1:3. 
114

Bine KRAMBERGER

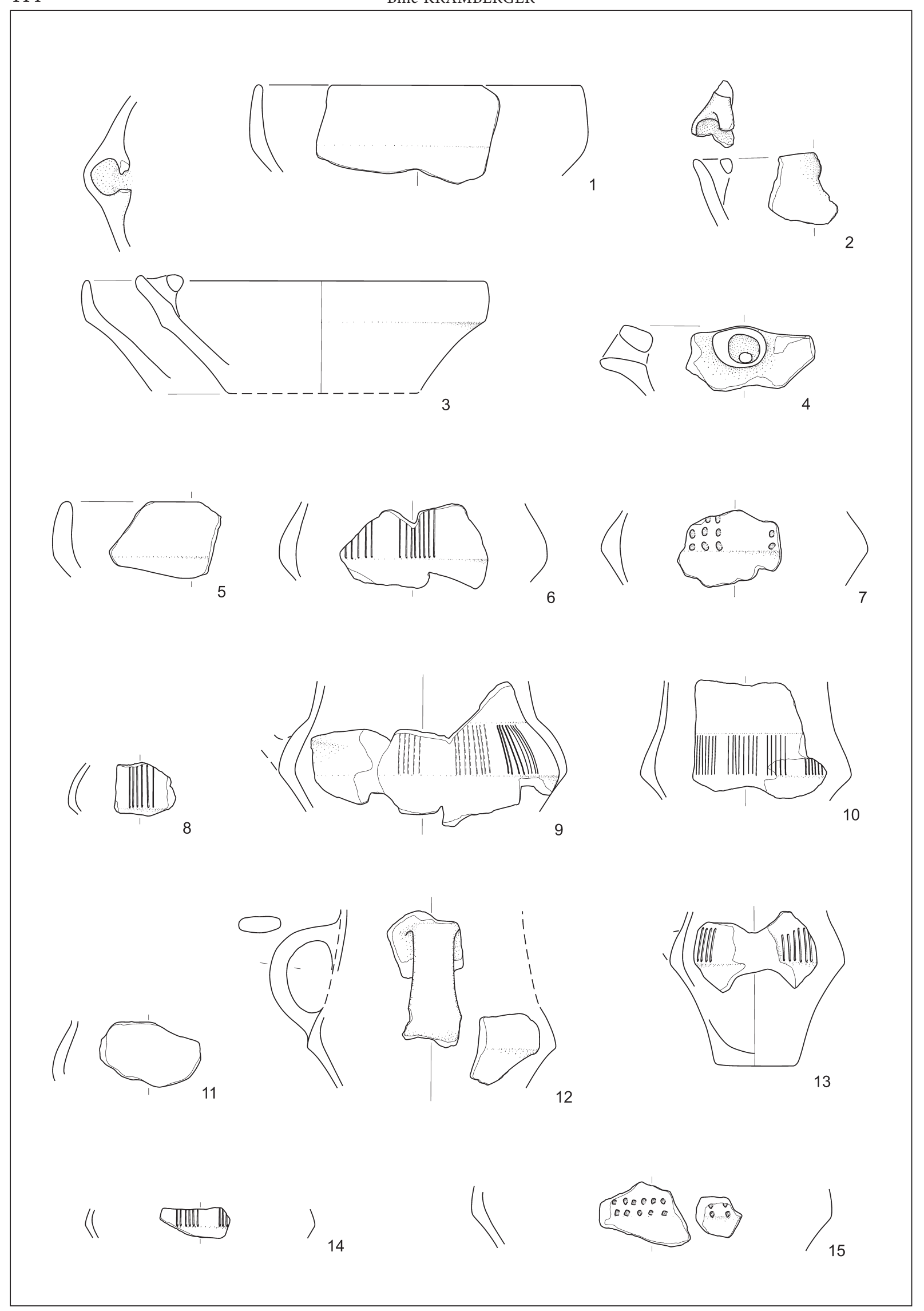

T. 3: Spodnje Hoče - Orglarska delavnica. Zemljanka I (1989). Vse keramika. M. = 1:3.

Pl. 3: Spodnje Hoče - Orglarska delavnica. Pit-house I (1989). All pottery. Scale = 1:3. 


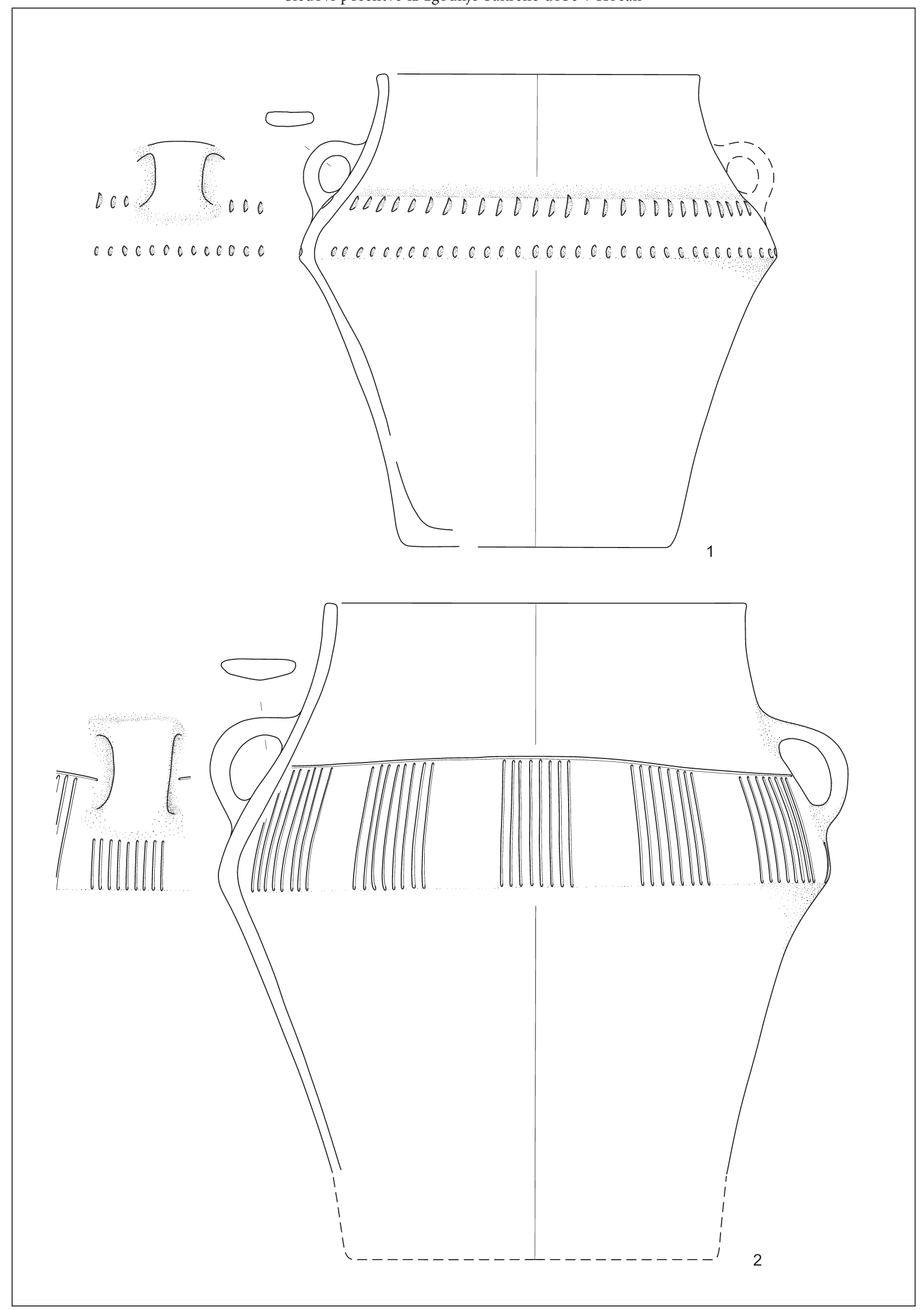

T. 4: Spodnje Hoče - Orglarska delavnica. Zemljanka I (1989). Vse keramika. M. = 1:3.

Pl. 4: Spodnje Hoče - Orglarska delavnica. Pit-house I (1989). All pottery. Scale = 1:3. 

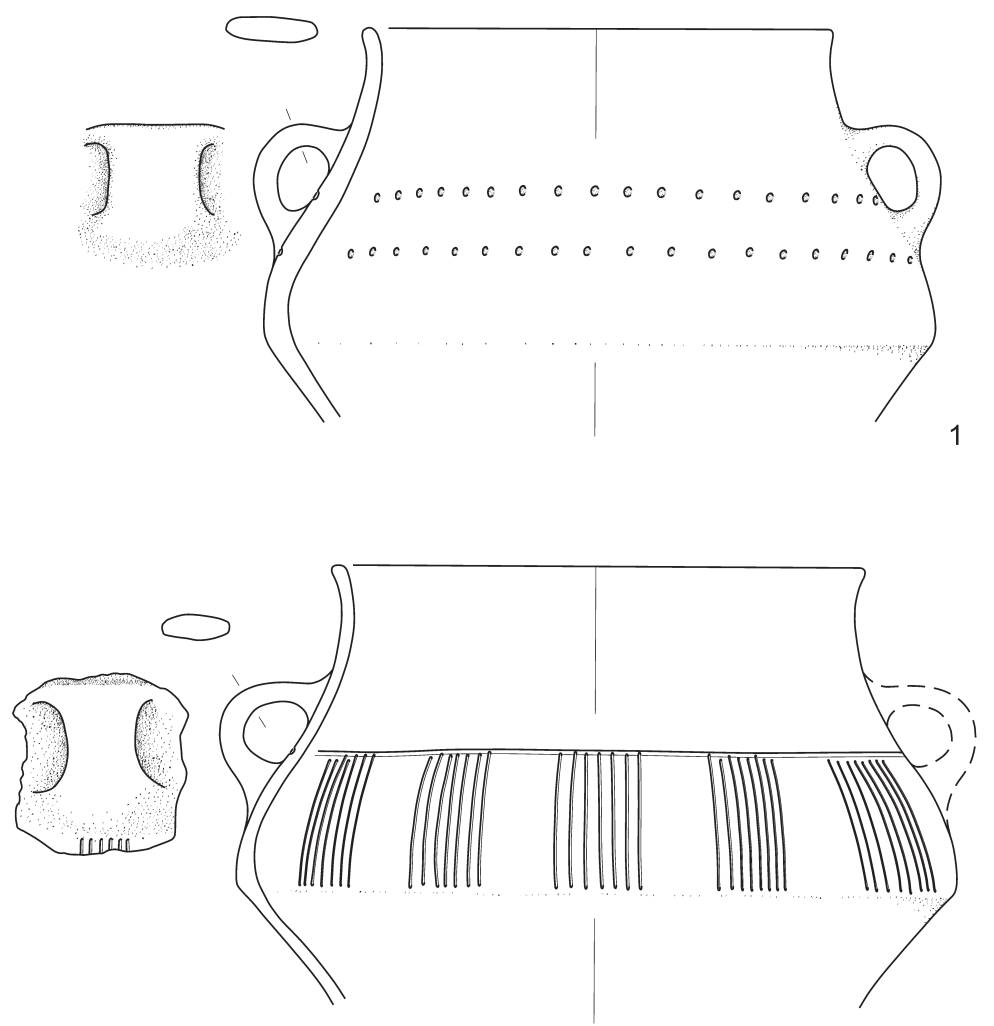

2
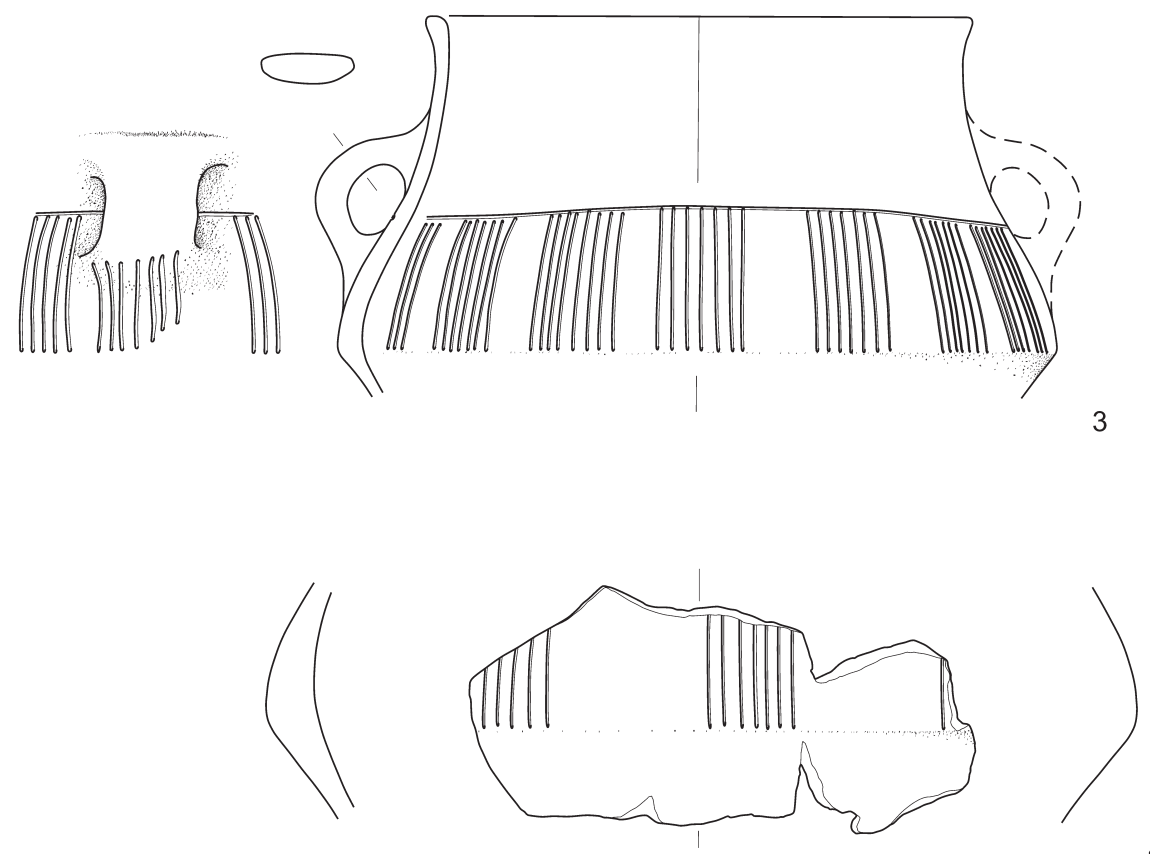

T. 5: Spodnje Hoče - Orglarska delavnica. Zemljanka I (1989). Vse keramika. M. = 1:3.

Pl. 5: Spodnje Hoče - Orglarska delavnica. Pit-house I (1989). All pottery. Scale = 1:3. 


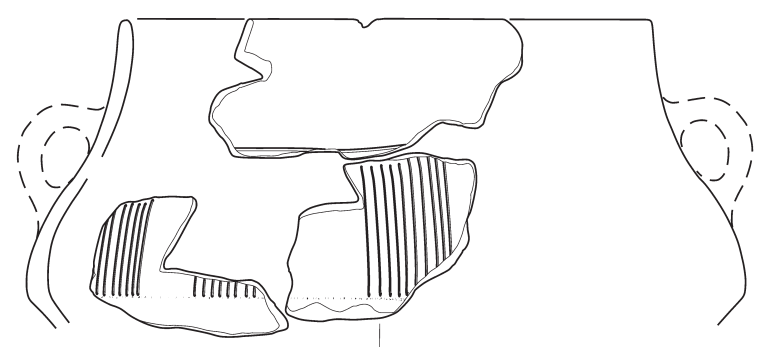

1
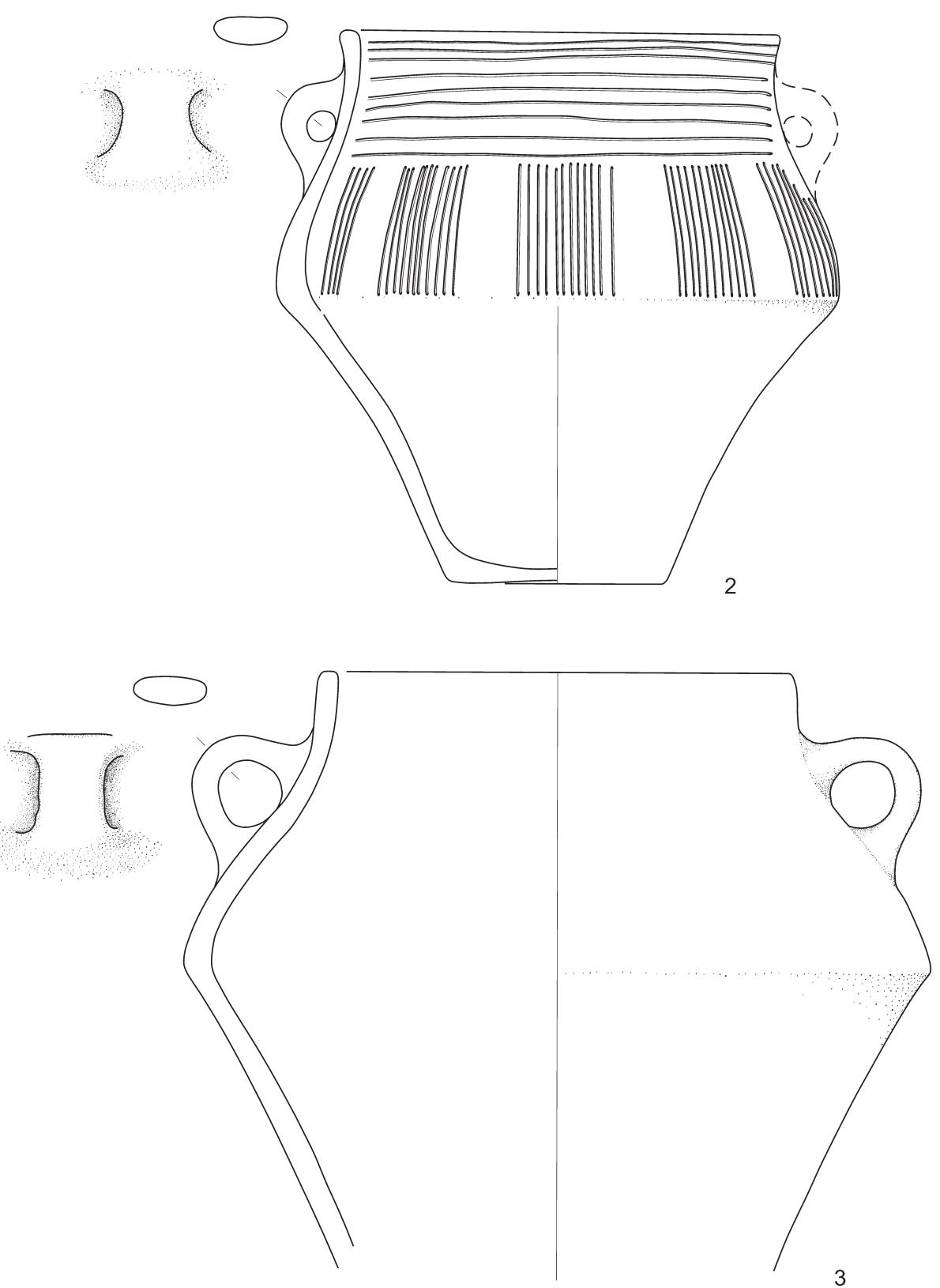

T. 6: Spodnje Hoče - Orglarska delavnica. Zemljanka I (1989). Vse keramika. M. = 1:3.

Pl. 6: Spodnje Hoče - Orglarska delavnica. Pit-house I (1989). All pottery. Scale = 1:3. 

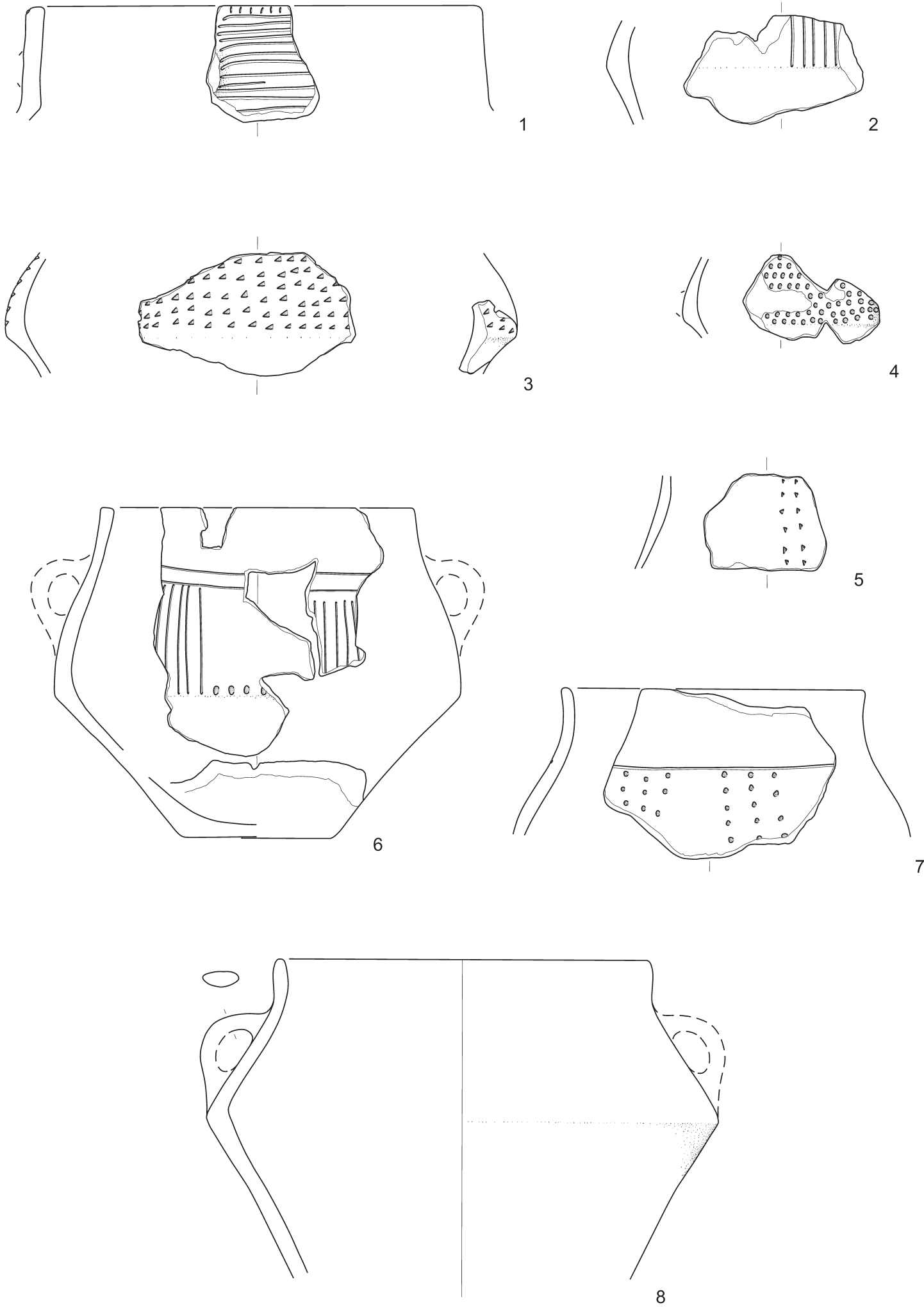

T. 7: Spodnje Hoče - Orglarska delavnica. Zemljanka I (1989). Vse keramika. M. = 1:3.

Pl. 7: Spodnje Hoče - Orglarska delavnica. Pit-house I (1989). All pottery. Scale = 1:3. 
Sledovi poselitve iz zgodnje bakrene dobe v Hočah

119
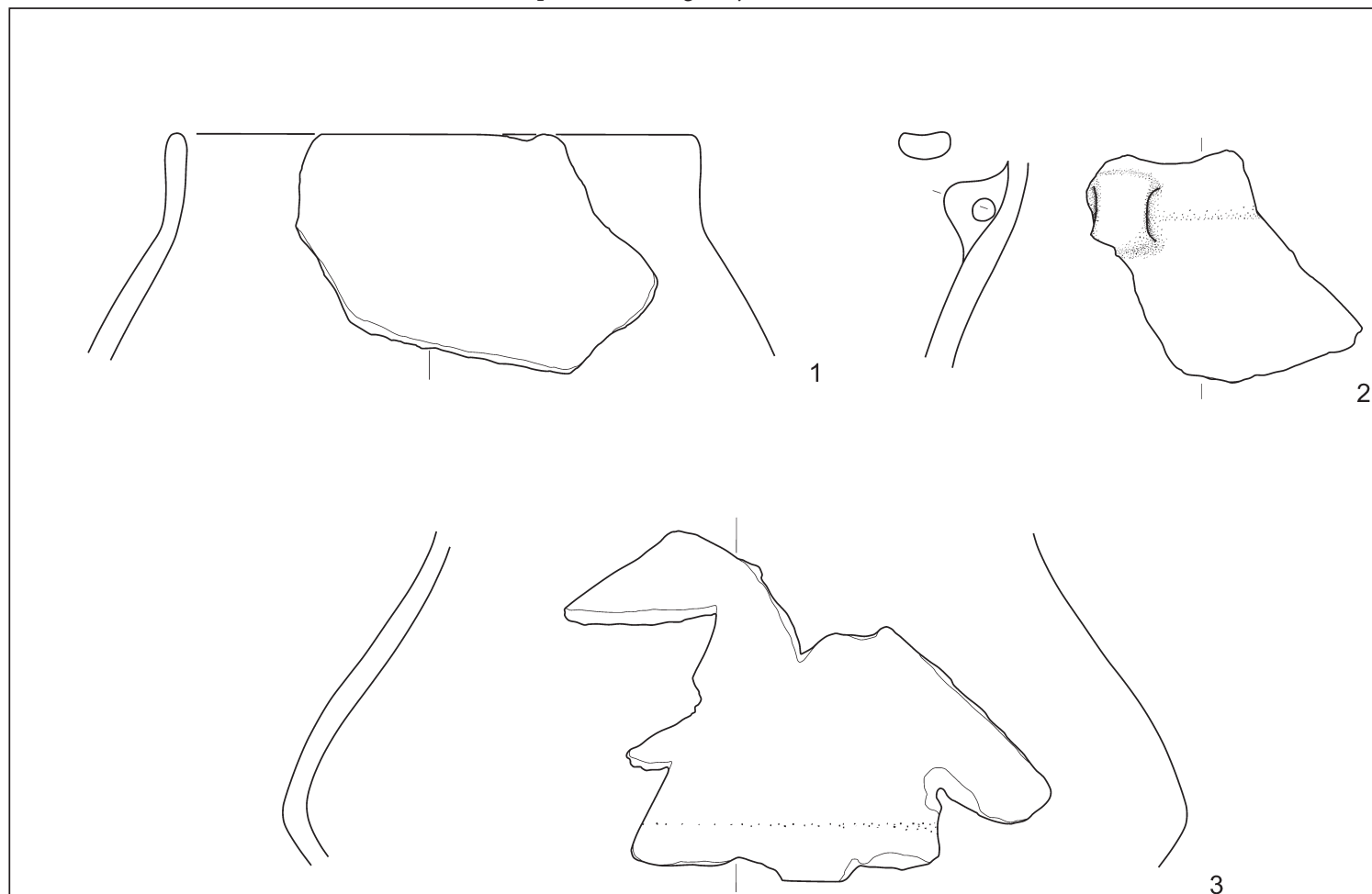

3
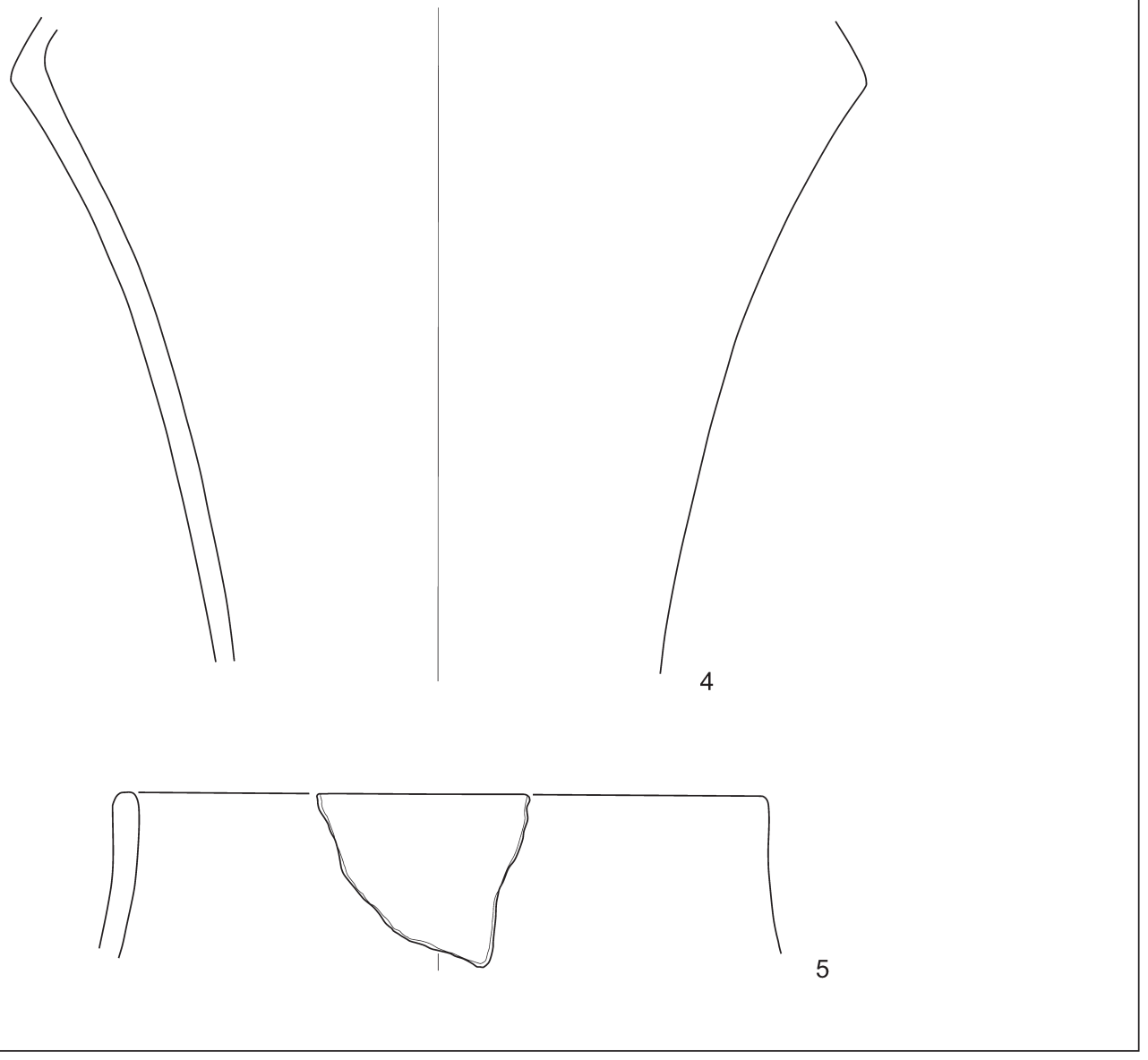

T. 8: Spodnje Hoče - Orglarska delavnica. Zemljanka I (1989). Vse keramika. M. = 1:3.

Pl. 8: Spodnje Hoče - Orglarska delavnica. Pit-house I (1989). All pottery. Scale = 1:3. 

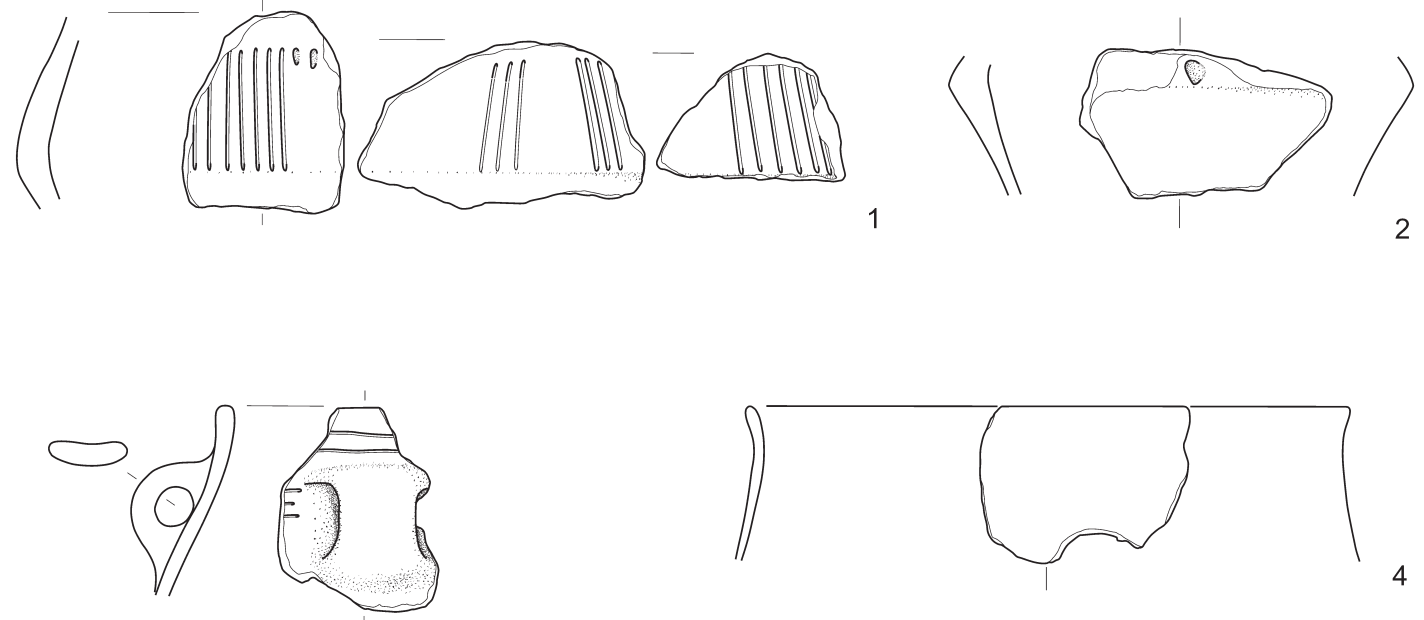

3
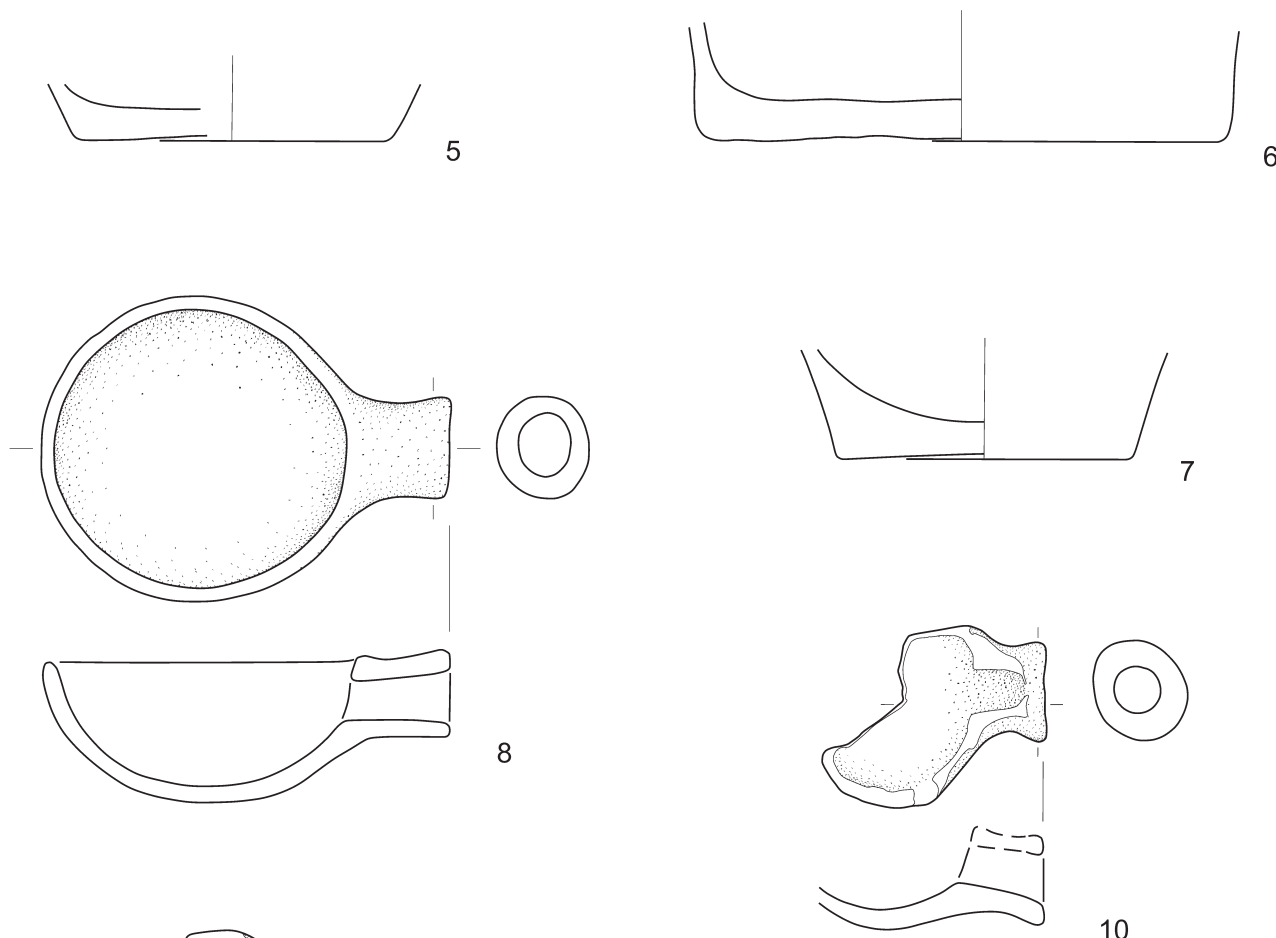

10
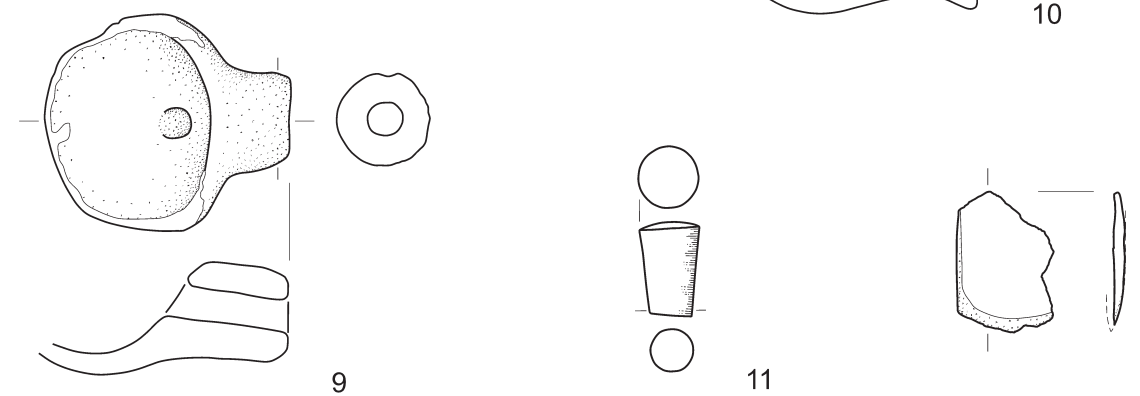

11

12

T. 9: Spodnje Hoče - Orglarska delavnica. Zemljanka I (1989). 1-10 keramika; 11,12 kamen. M. = 1:3.

Pl. 9: Spodnje Hoče - Orglarska delavnica. Pit-house I (1989). 1-10 pottery; 11,12 stone. Scale = 1:3. 
Sledovi poselitve iz zgodnje bakrene dobe v Hočah

121
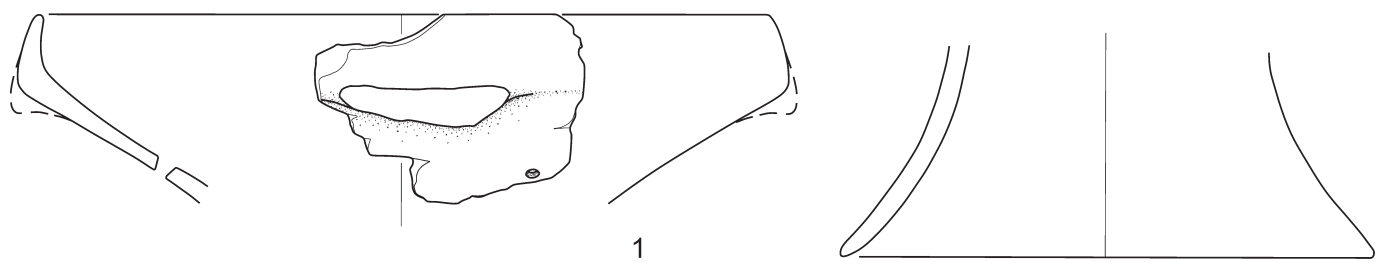

2
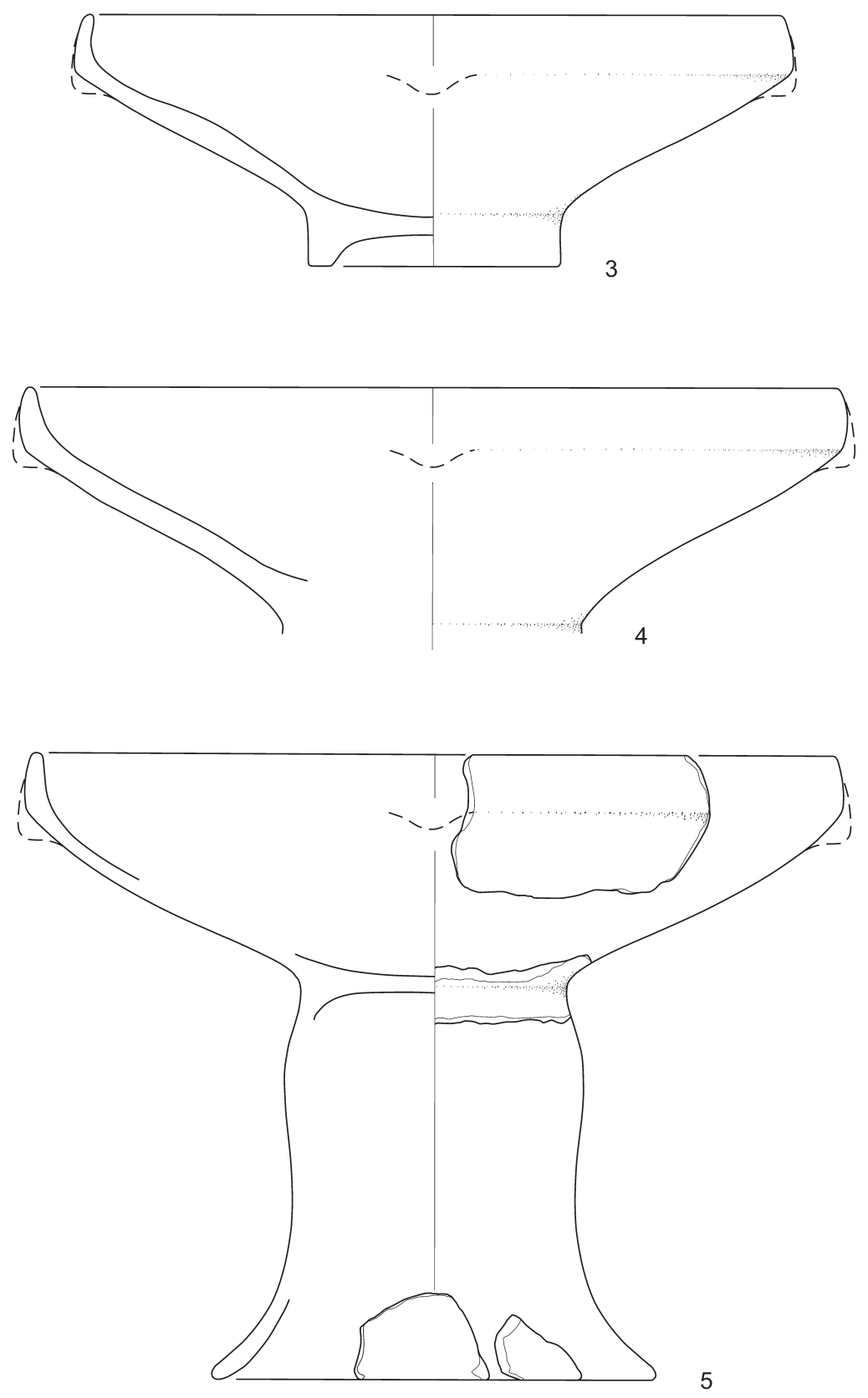

T. 10: Spodnje Hoče - Orglarska delavnica. Zemljanka II (1989). Vse keramika. M. = 1:3.

Pl. 10: Spodnje Hoče - Orglarska delavnica. Pit-house II (1989). All pottery. Scale = 1:3. 

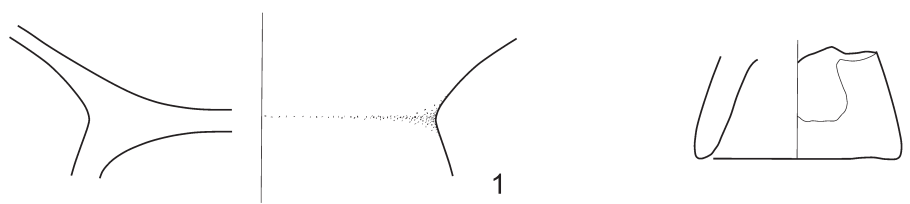

2
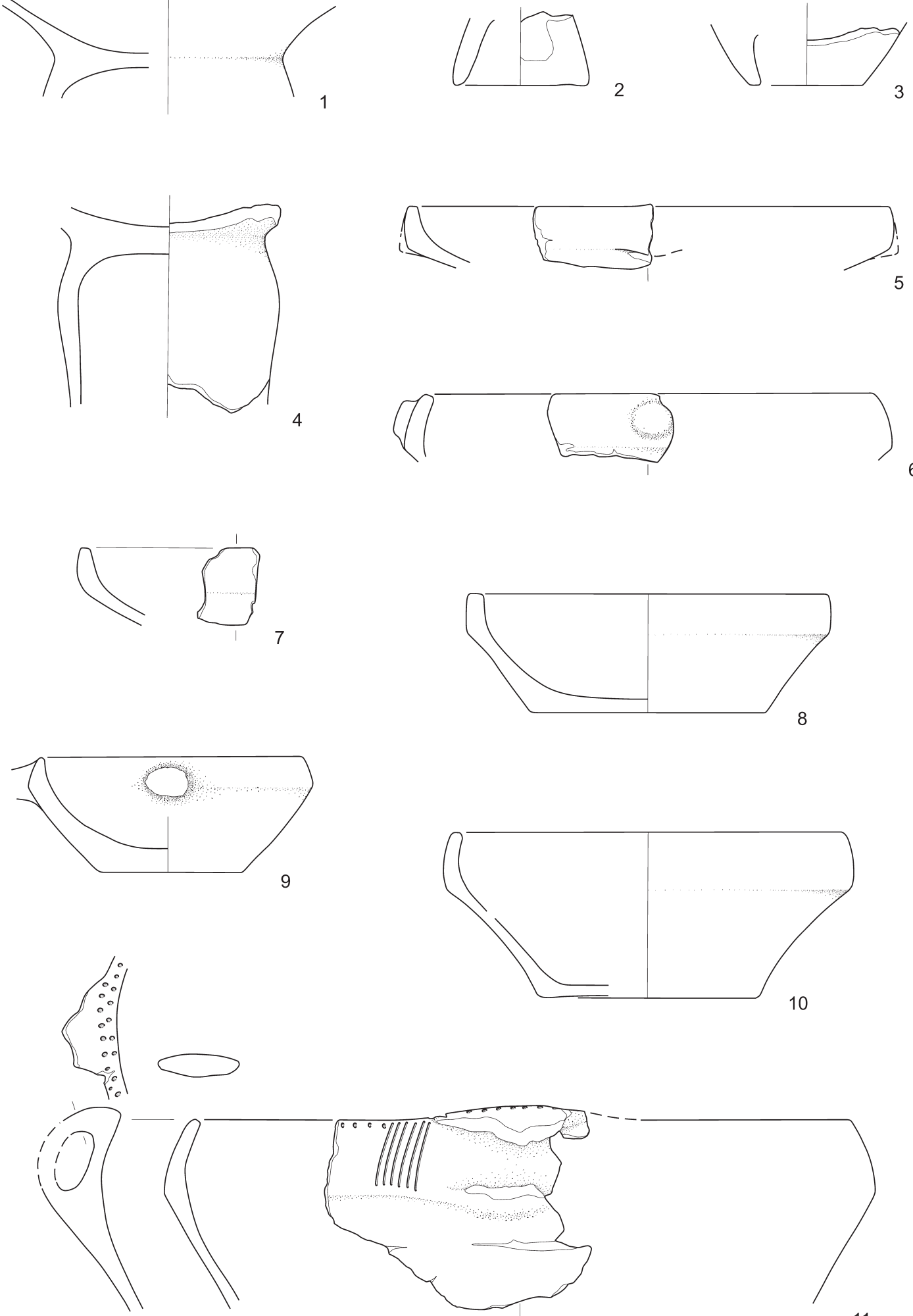

10
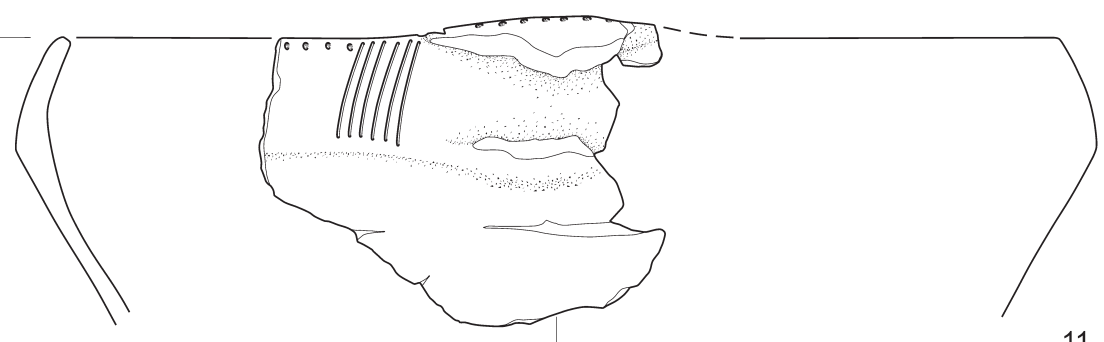

11

T. 11: Spodnje Hoče - Orglarska delavnica. Zemljanka II (1989). Vse keramika. M. = 1:3.

Pl. 11: Spodnje Hoče - Orglarska delavnica. Pit-house II (1989). All pottery. Scale = 1:3. 


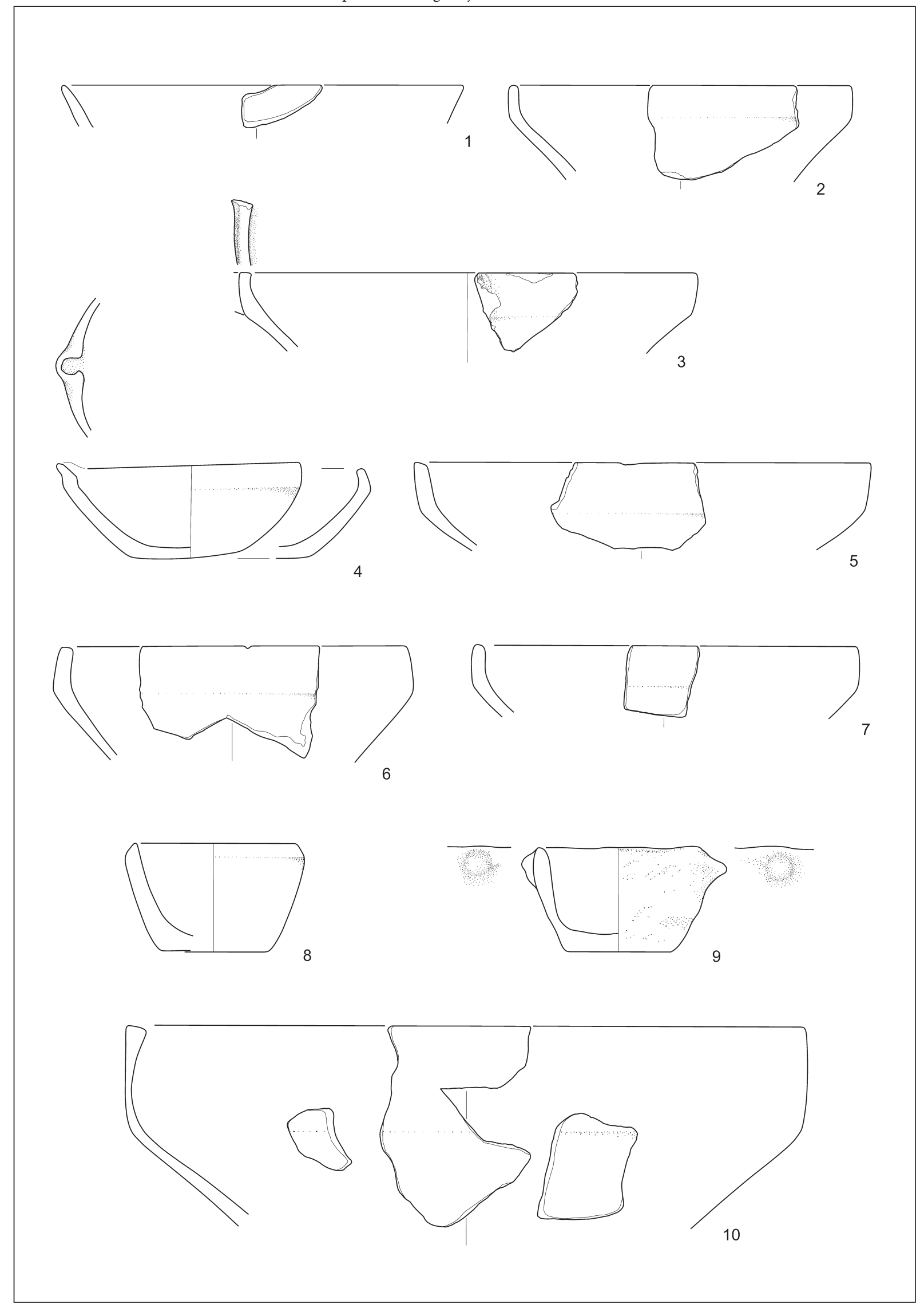

T. 12: Spodnje Hoče - Orglarska delavnica. Zemljanka II (1989). Vse keramika. M. = 1:3.

Pl. 12: Spodnje Hoče - Orglarska delavnica. Pit-house II (1989). All pottery. Scale = 1:3. 

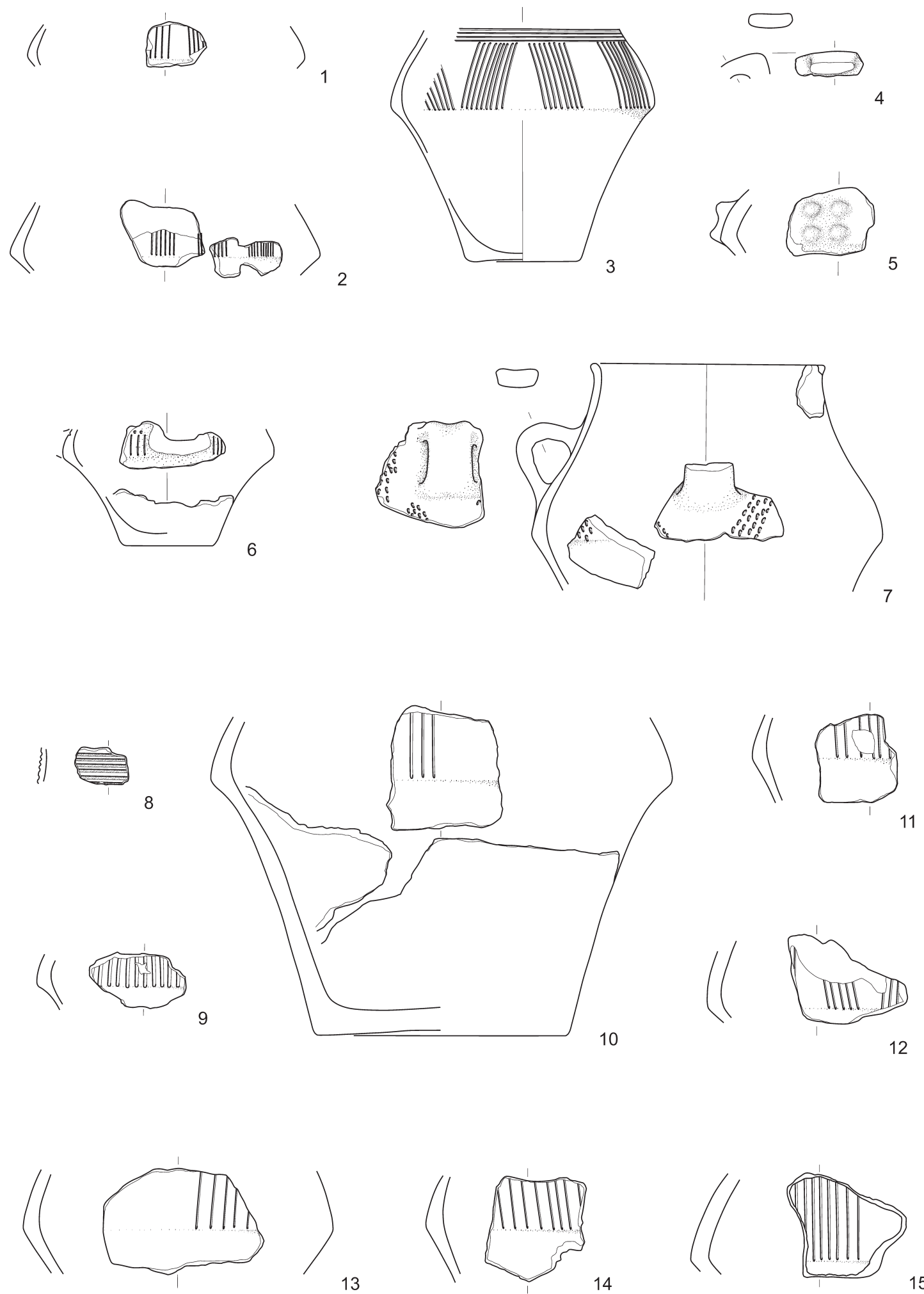

T. 13: Spodnje Hoče - Orglarska delavnica. Zemljanka II (1989). Vse keramika. M. = 1:3.

Pl. 13: Spodnje Hoče - Orglarska delavnica. Pit-house II (1989). All pottery. Scale = 1:3. 

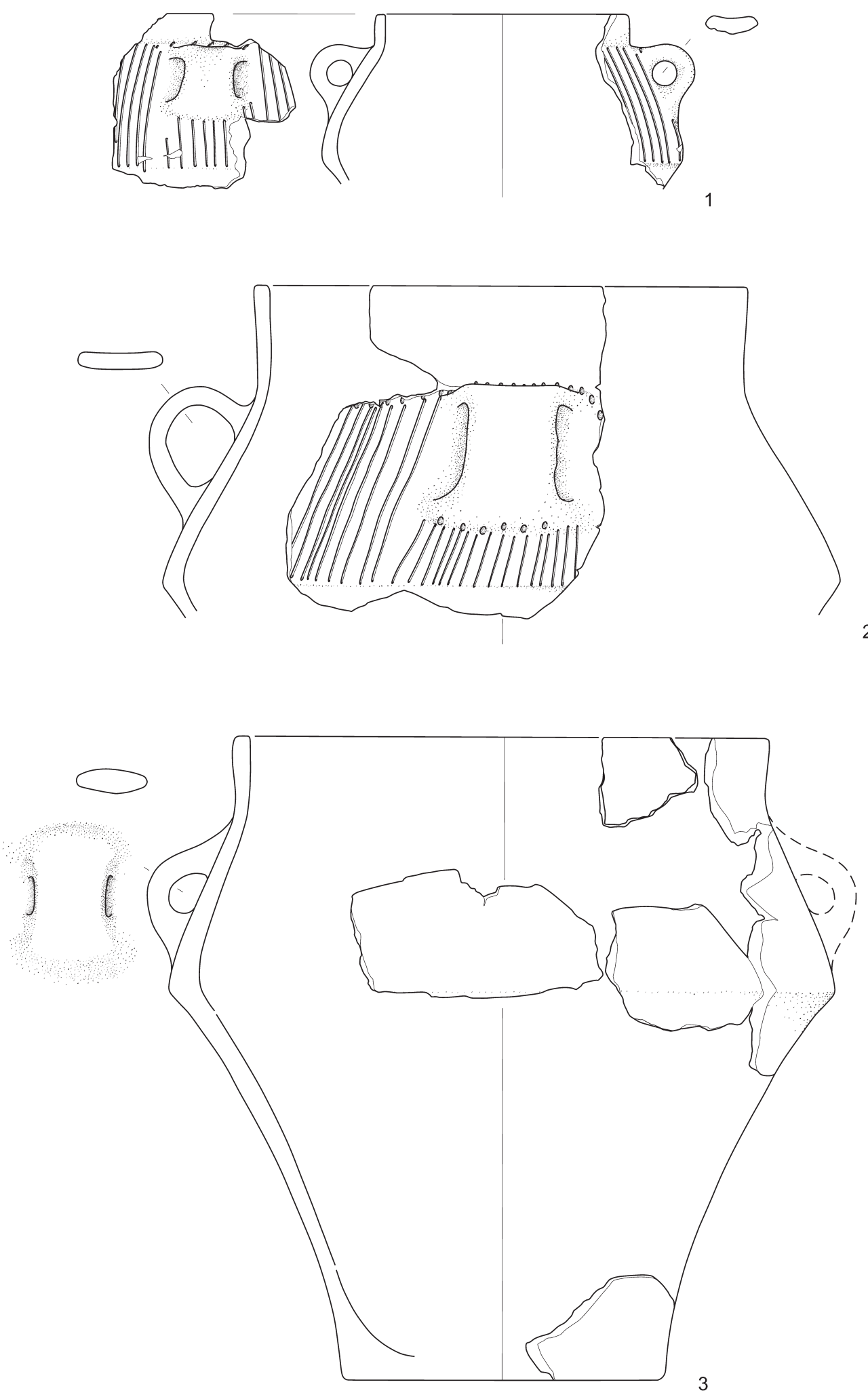

T. 14: Spodnje Hoče - Orglarska delavnica. Zemljanka II (1989). Vse keramika. M. = 1:3

Pl. 14: Spodnje Hoče - Orglarska delavnica. Pit-house II (1989). All pottery. Scale = 1:3. 
126

Bine KRAMBERGER
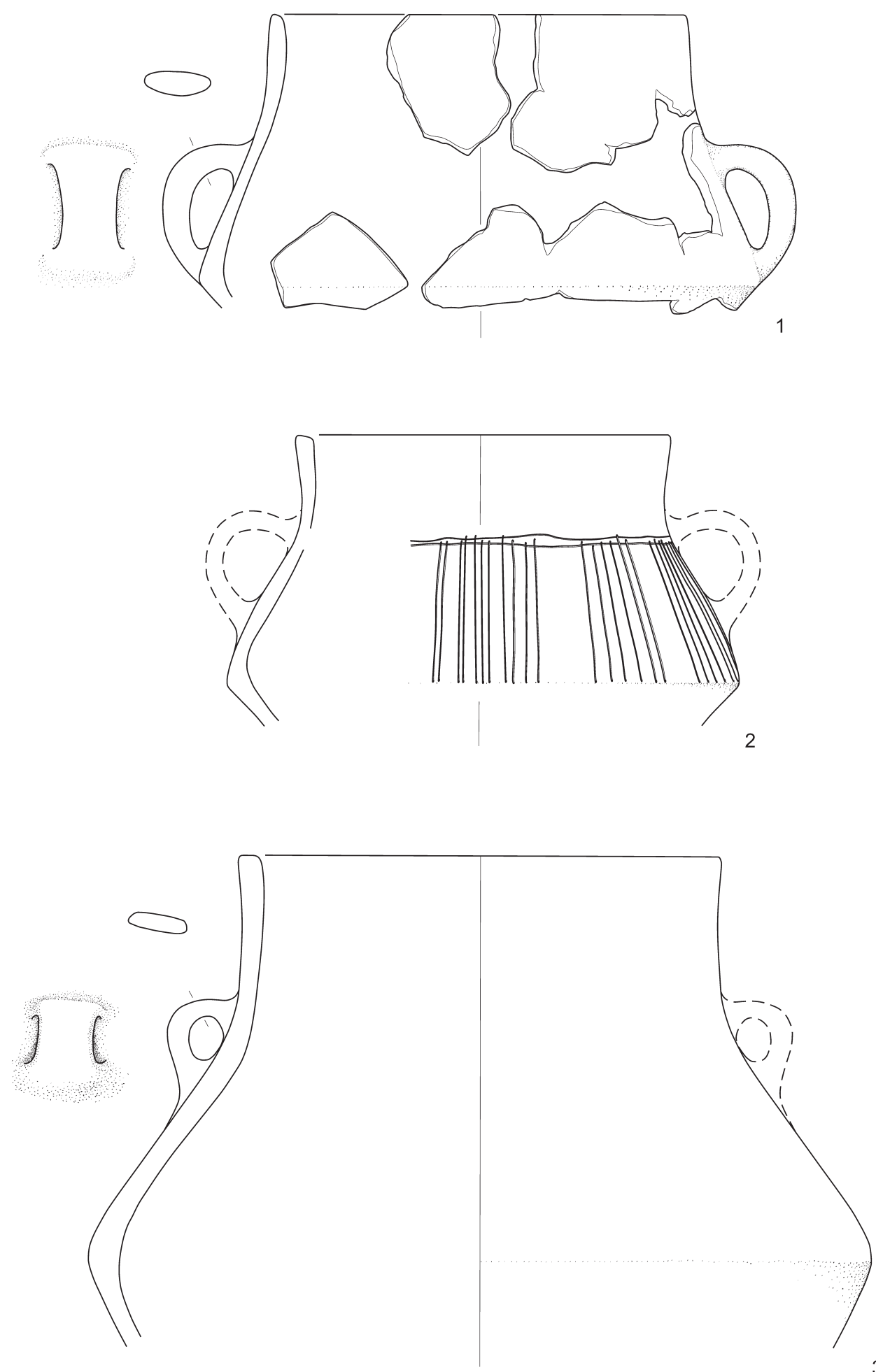

3

T. 15: Spodnje Hoče - Orglarska delavnica. Zemljanka II (1989). Vse keramika. M. = 1:3. Pl. 15: Spodnje Hoče - Orglarska delavnica. Pit-house II (1989). All pottery. Scale = 1:3. 

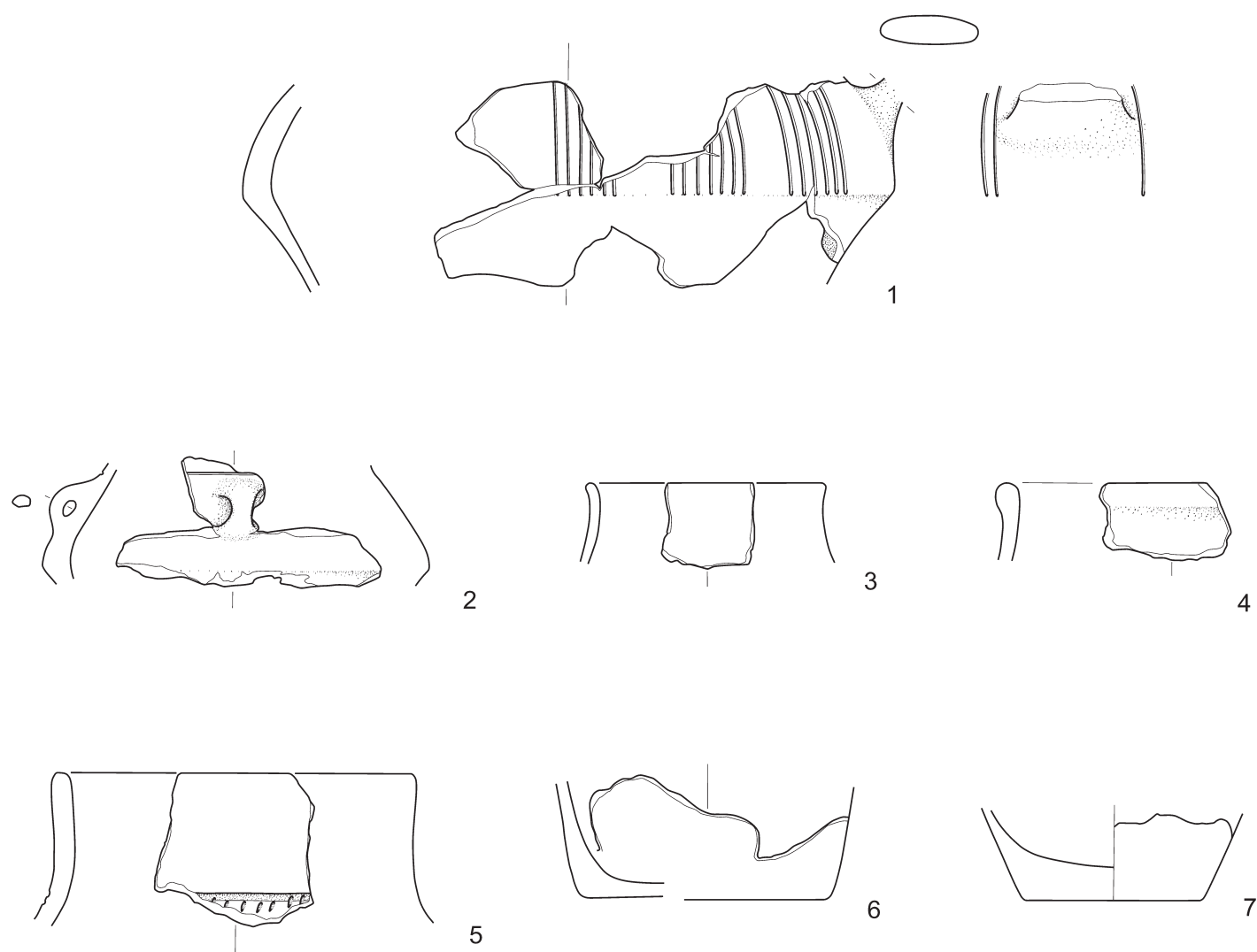

5

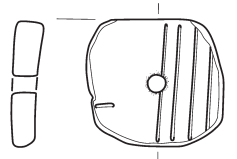

8

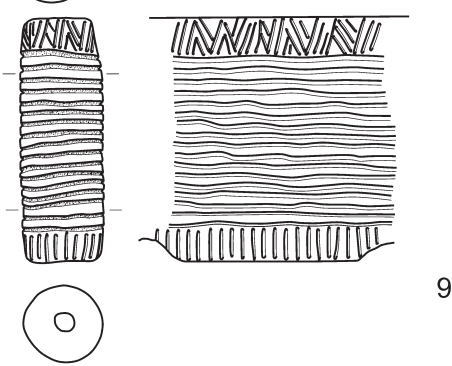

9
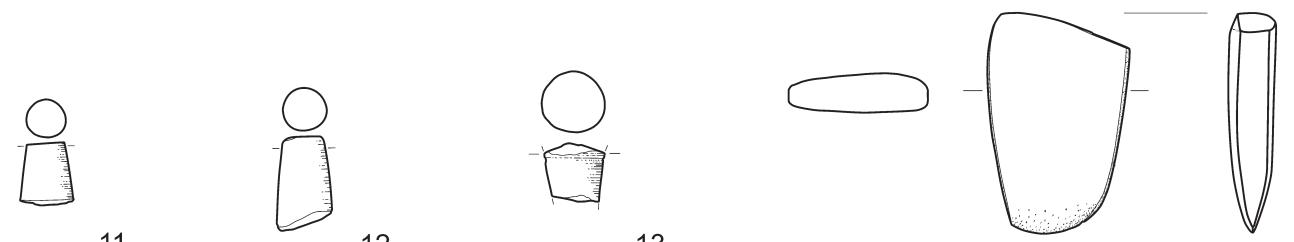

12

13

14

T. 16: Spodnje Hoče - Orglarska delavnica. Zemljanka II (1989). Keramika; 11-14 kamen. M. = 1:3.

Pl. 16: Spodnje Hoče - Orglarska delavnica. Pit-house II (1989). Pottery; 11-14 stone. Scale = 1:3. 


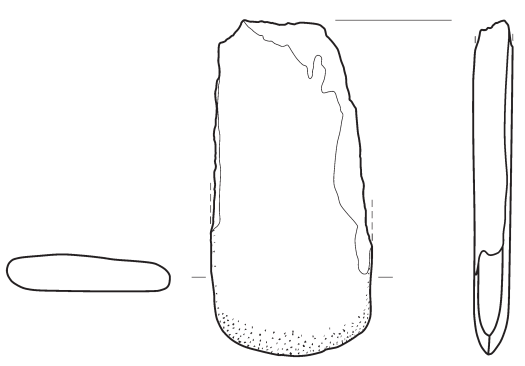

1
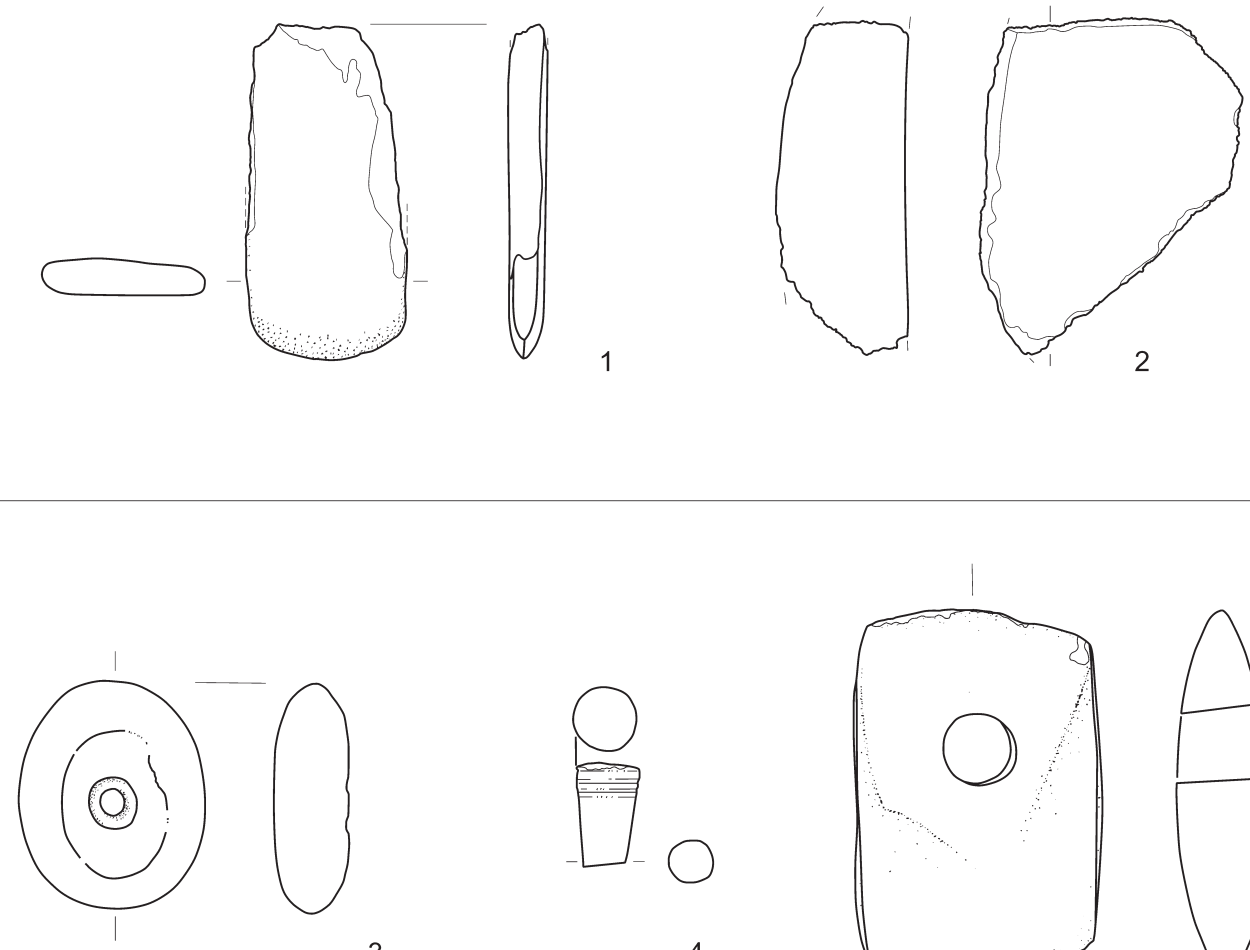

3
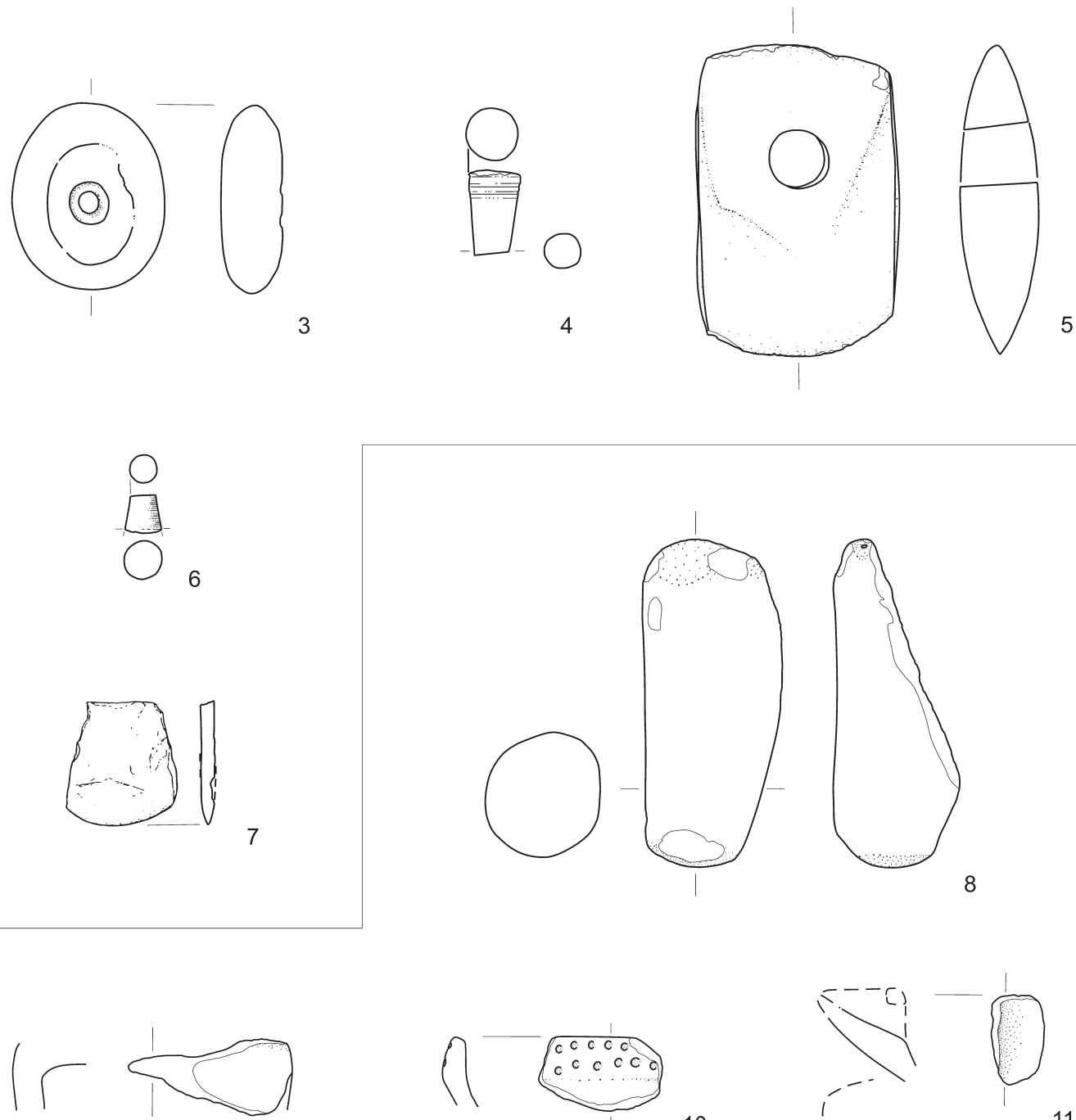

10

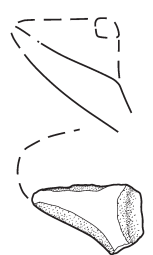

11

T. 17: Spodnje Hoče - Orglarska delavnica. 1-2 zemljanka II (1989); 3-5 zemljanka II ali zemljanka III (1989); 6-7 zemljanka III (1989?); 8-11 zemljanka III (1989). Kamen; 9-11 keramika. M. = 1:3.

Pl. 17: Spodnje Hoče - Orglarska delavnica. 1-2 Pit-house II (1989); 3-5 Pit-house II or Pit-house III (1989); 6-7 Pit-house III (1989?); 8-11 Pit-house III (1989). Stone; 9-11 pottery. Scale = 1:3. 
Sledovi poselitve iz zgodnje bakrene dobe v Hočah

129

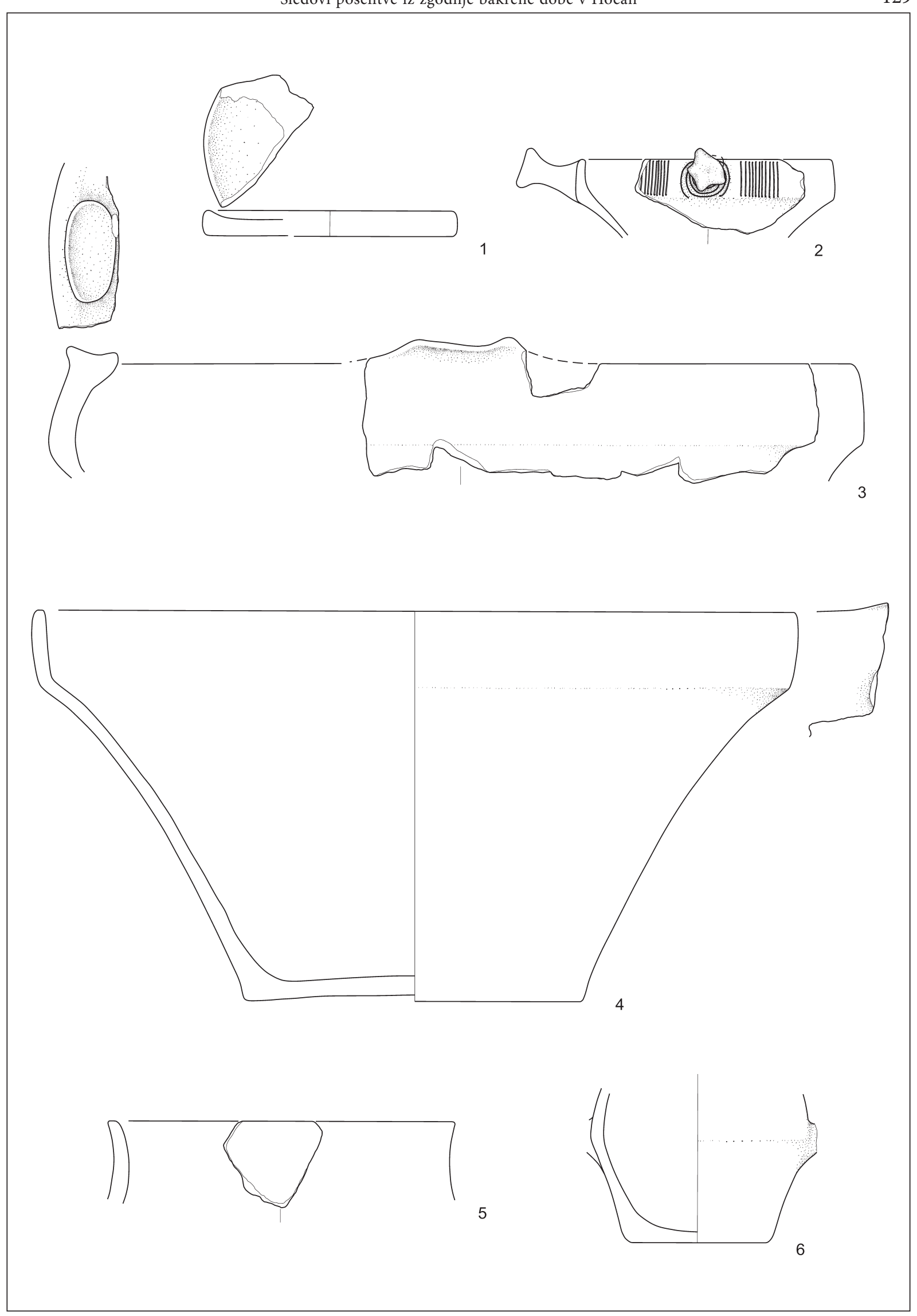

T. 18: Spodnje Hoče - Orglarska delavnica. Zemljanka III (1989). Vse keramika. M. = 1:3. Pl. 18: Spodnje Hoče - Orglarska delavnica. Pit-house III (1989). All pottery. Scale = 1:3. 

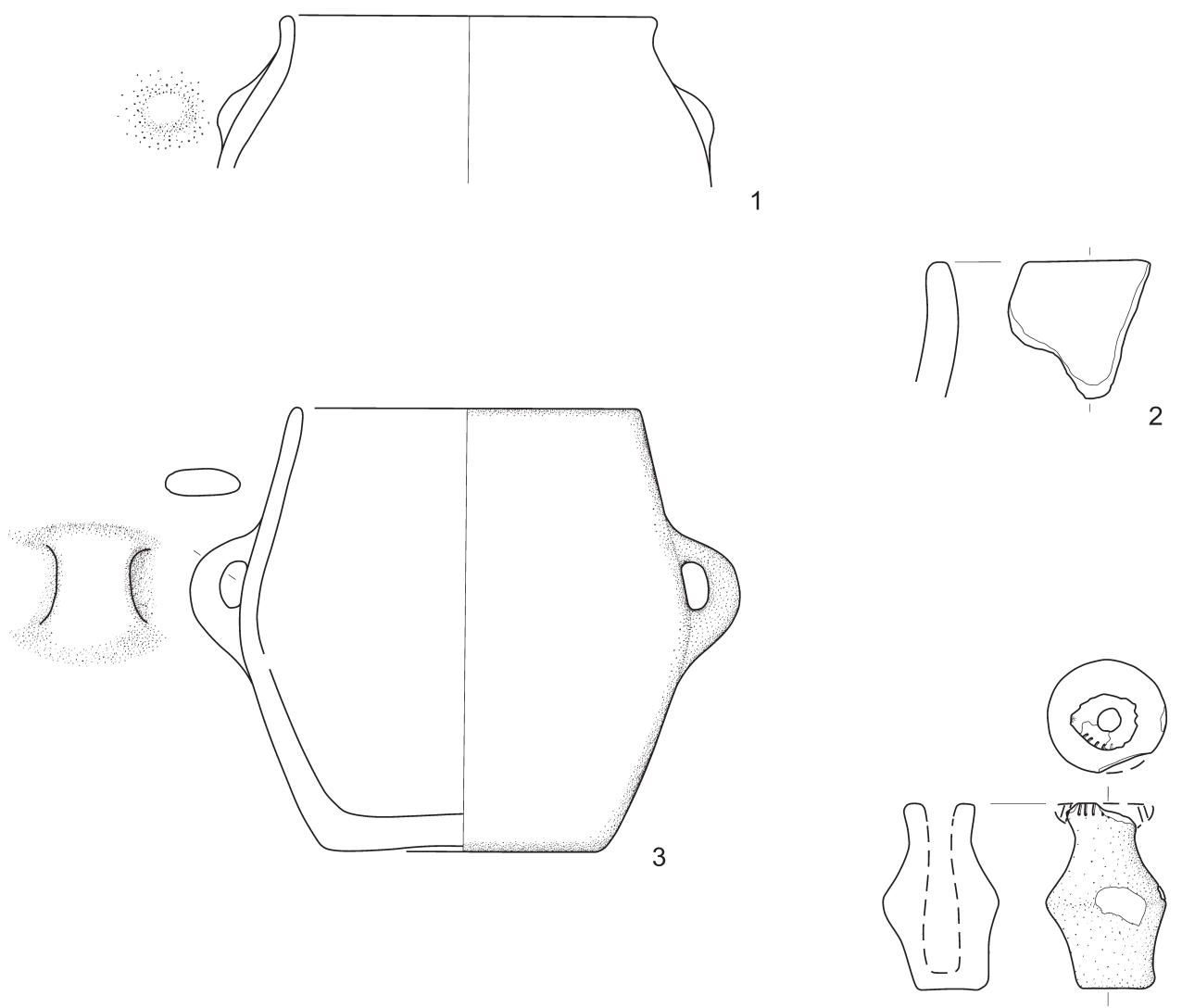

4

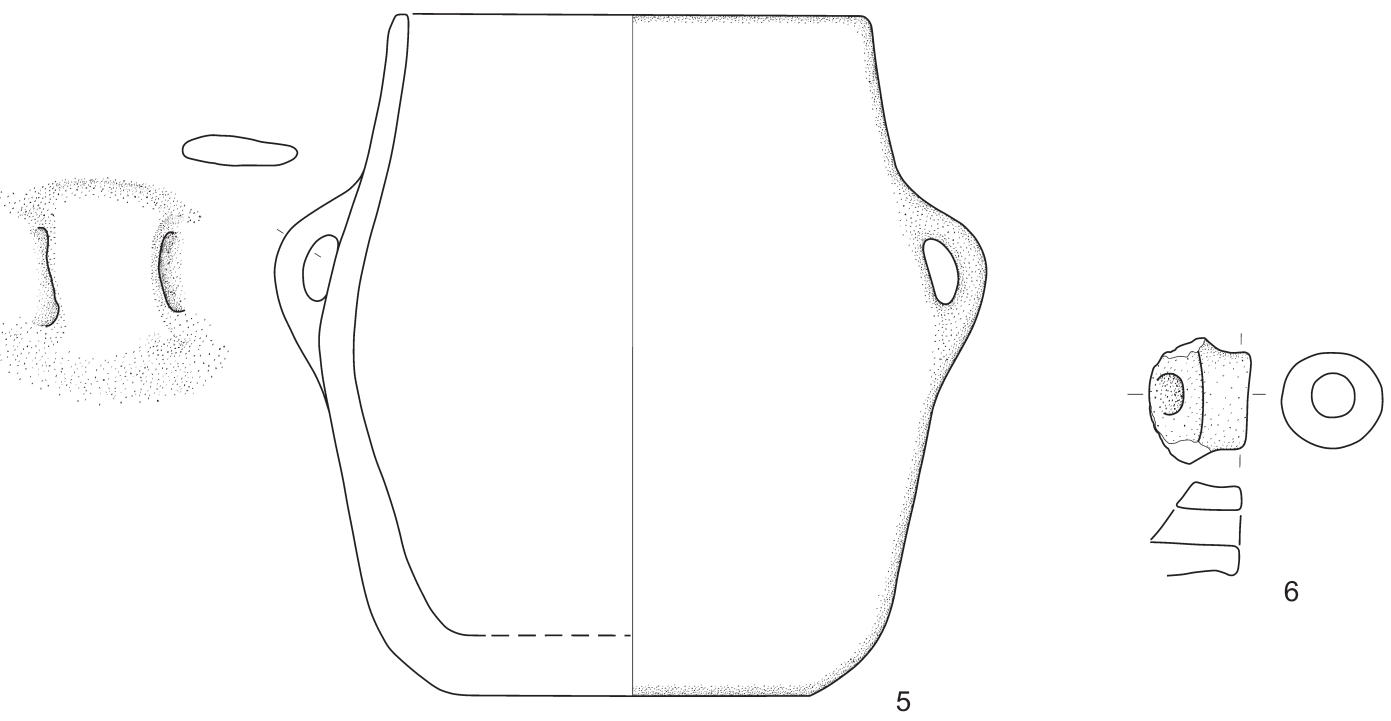

T. 19: Spodnje Hoče - Orglarska delavnica. Zemljanka III (1989). Vse keramika. M. = 1:3.

Pl. 19: Spodnje Hoče - Orglarska delavnica. Pit-house III (1989). All pottery. Scale = 1:3. 


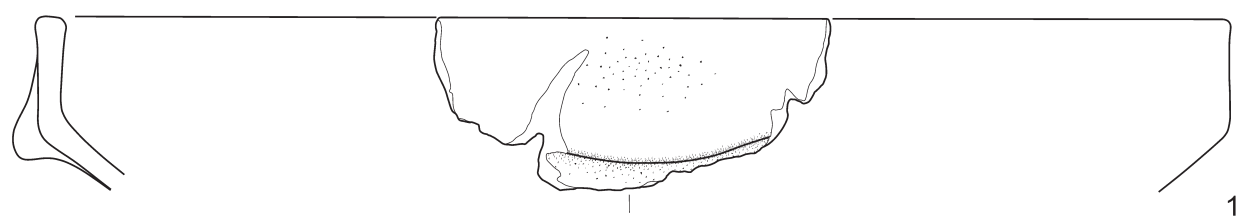

2
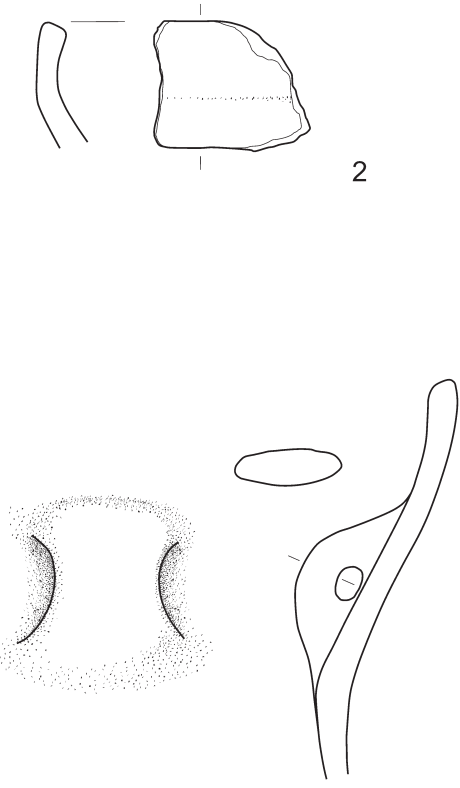

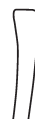
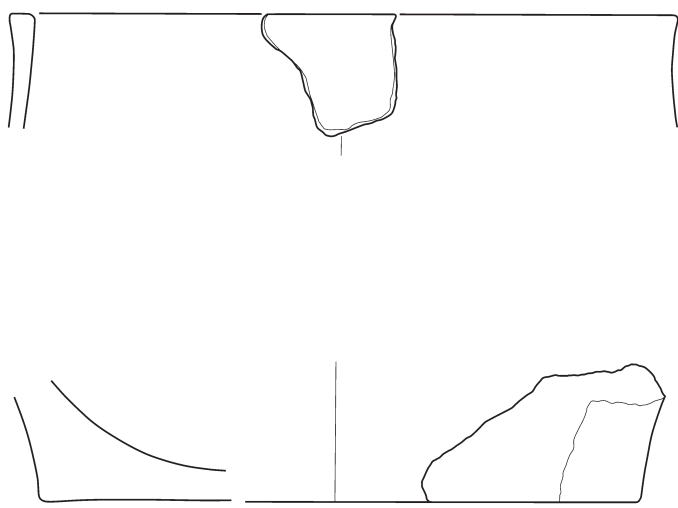

9
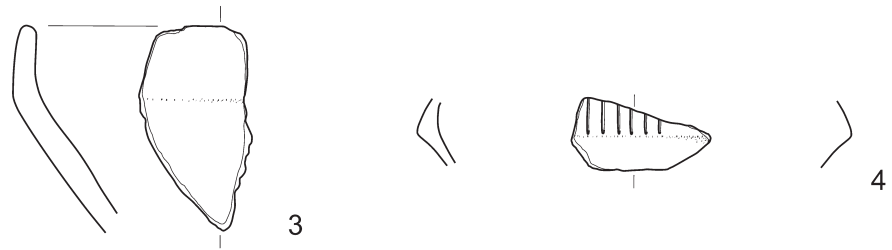
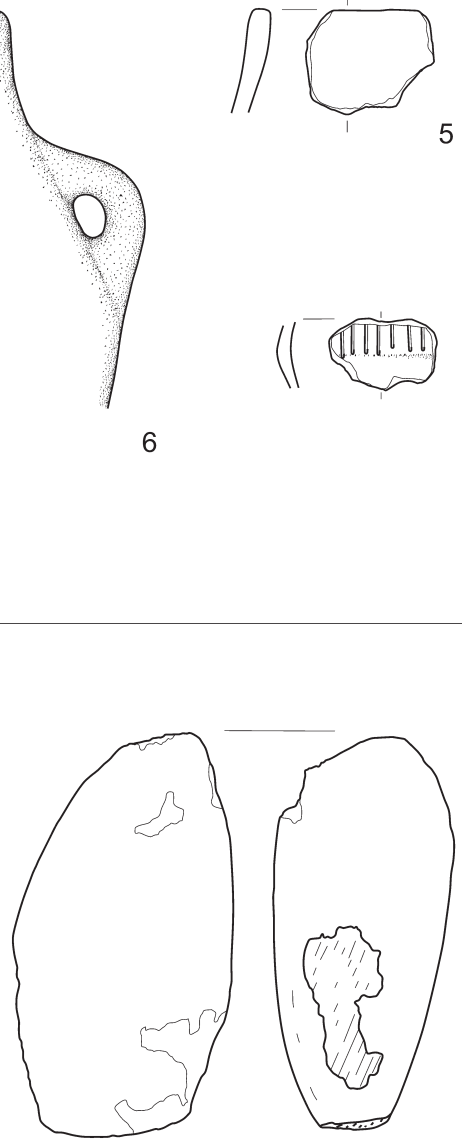

10

T. 20: Spodnje Hoče - Orglarska delavnica. 1 jama II (1988)?; 2-9 jama II (1988); 10 jama I (1988). Keramika; 10 kamen. M. $=1: 3$.

Pl. 20: Spodnje Hoče - Orglarska delavnica. 1 Pit II (1988)?; 2-9 Pit II (1988); 10 Pit I (1988). Pottery; 10 stone. Scale = 1:3. 

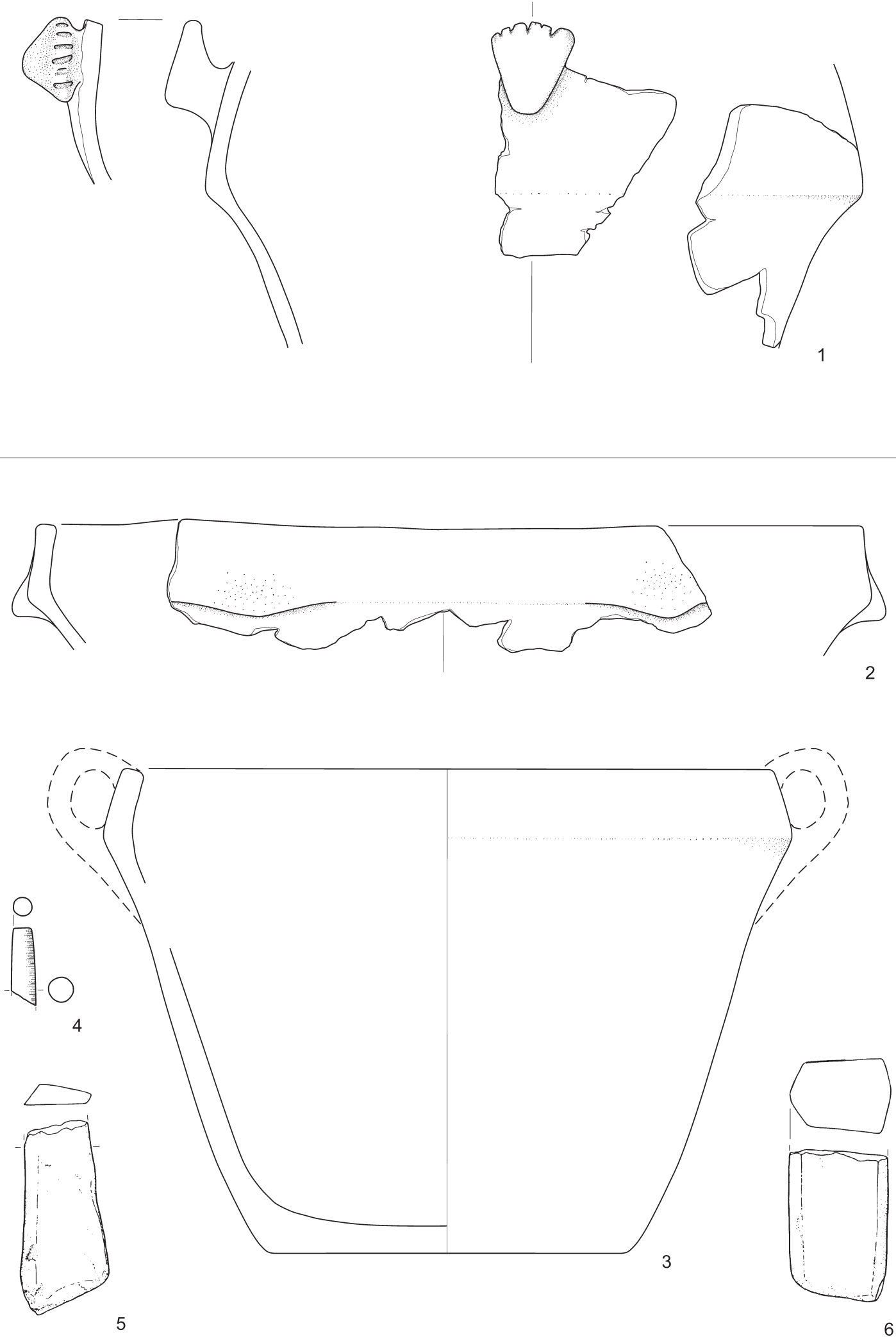

T. 21: Spodnje Hoče - Orglarska delavnica. 1 jama za stojko 7 (1988); 2, 3, 5, 6 neznan kontekst; 4 nad prazgodovinsko plastjo (1989). 1-3 keramika; 4-6 kamen. M. = 1:3.

Pl. 21: Spodnje Hoče - Orglarska delavnica. 1 Post-hole 7 (1988); 2, 3, 5, 6 unknown context; 4 above prehistoric layer (1989). 1-3 pottery; 4-6 stone. Scale = 1:3. 